\title{
Proceedings and Findings of the Geothermal Commercialization Workshop
}

\author{
J. Anderson \\ H. Dhillon
}

April 1979

This book was prepared as an account of work sponsored by an agency of the United States Government Neither the United States Government nor any agency thereof, nor any of their employees. makes any warranty, express or implied, or assumes any legal lisbility or responsibinty for the accuracy,

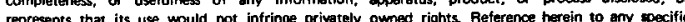

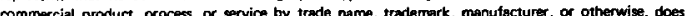
nor necescerily constivtes of Imply its endorsement recomnendation, of fworing by the United States Government or any agency therroot. The views and opinions of authors expressed herein do mot necessarily state or reflect those of the United States Government or any wency thereot.

MTR-80W271

Sponsor: Department of Energy

Division of Geothermal Energy

Contract No.: EG-77-C-01-4014

The MITRE Corporation

Metrek Division

1820 Dolley Madison Boulevard

McLean, Virginia 22102 


\section{DISCLAIMER}

This report was prepared as an account of work sponsored by an agency of the United States Government. Neither the United States Government nor any agency Thereof, nor any of their employees, makes any warranty, express or implied, or assumes any legal liability or responsibility for the accuracy, completeness, or usefulness of any information, apparatus, product, or process disclosed, or represents that its use would not infringe privately owned rights. Reference herein to any specific commercial product, process, or service by trade name, trademark, manufacturer, or otherwise does not necessarily constitute or imply its endorsement, recommendation, or favoring by the United States Government or any agency thereof. The views and opinions of authors expressed herein do not necessarily state or reflect those of the United States Government or any agency thereof. 


\section{DISCLAIMER}

Portions of this document may be illegible in electronic image products. Images are produced from the best available original document. 


\section{ABSTRACT}

This paper presents the proceedings of a Geothermal Commerclalization Workshop conducted by the Division of Geothermal Resource Management, Department of Energy. The workshop was held in January-February 1979 at The MITRE Corporation facility in McLean, Virginia. The workshop addressed geothermal hydrothermal commerclalization achievements and needs in the areas of Marketing and Outreach, Economics, Scenarios, and Progress Monitoring. 
TABLE OF CONTENTS

Page

List of Illustrations

List of Tables

$\mathbf{v i}$

List of Acronyms

vi11

SUMMARY

$5-1$

SECTION 1 - MARKETING AND OUTREACE

1-1

Marketing Committee - $1-3$

Sumary

Attachments 1 - Steps in Geothermal Resource Comer-

$1-5$ clalization

Attachment 2 - Direct Application Commercialization 1-13 Matrix

Attachment 3 - Electric Applications Comerclalization 1-17 Matr1x

Attachment 4 - Market Analysis Matrix - Example $1-21$

Attachment 5 - Needs Assessment for Commercialization 1-25

Attachment 6 - Documents List

$1-33$

Attachment 7 - Current Program Marketing Summaries 1-39

Technical Assistance

Special Programs

Project Brokering

State and Local Policy Activities

Public Information

$1-41$

$1-43$

$1-47$

$1-51$

$1-55$

Workshops, Conferences, Symposia

$1-59$

Financial Incentives

$1-63$

$\begin{array}{cr}\text { Attachment } 8 \text { - Ideal Program Marketing Summaries } & 1-67 \\ \text { Technical Assistance } & 1-69\end{array}$

Speclal Programs

$1-71$

$1-75$

Recomended Project Brokering

$1-77$

State Pollcy Activities

$1-79$

Public Information

$\begin{array}{lr}\text { Workships, Conferences, Symposia } & 1-81 \\ \text { Financlal Assistance } & 1-83\end{array}$

Loan Guarantees

$1-87$

Agressive Assistance

$1-89$

$1-91$

Attachment 9 - Recommended Methodology for Market

Definition

Attachment 10 - International Marketing

$1-101$ 
TABLE OF CONTENTS CONT'D

SECTION 2 - ECONOMICS

Page

2-1

Report of The Economics Comittee

Sumary of The Findings of The Comittee

$2-3$

Objectives

$2-9$

The Role of Economics

$2-9$

Current Status and Identifled Research Needs

$2-10$

Issues Related to Supply and Demand

$2-13$

Cost Benefit Analysis

$2-15$

Regional Economic Analys is

2-16

Nugget Analysis

2-19

List of Nuggets

2-19

SECTION 3 - PLANNING FOR DEVELOPMENT - "SCENARIOS" 3-1

Sumary

$3-3$

Effort and Documents Reviewed

$3-7$

Appendix 3A - Discussion of Various Types of Planning

$3 A-1$

Tools in Scenarios

Appendix 3B - The Review of Prio Efforts

$3 B-1$

Eastern Region Planning Effort

Summary APL/JHV Planning Effort

$3 B-9$

$3 \mathrm{~B}-11$

The Rocky Mountain Region Planning Effort

$3 B-23$

Northwest Region Planning Effort

$3 B-29$

Pactific Reg1on Planning Effort

Appendix 3C - Recommendations for Future Scenarios

$3 B-41$

$3 C-1$

Appendix 3D - International Use of Geothermal Energy or

$3 D-1$

Marketing of United States Technology

Appendix 3E - The Need for Additfonal Planning Effort to 3E-1

Assist the Use of Bydrothermal for Space Heating

Appendix 3F - Guidelines for Developing Site Prospectives

Append1x 3G - Alternative User Oriented Scenarios

$3 F-1$

$3 G-1$

SECTION 4 - PROGRESS MONITORING

4-1

Committee Members

4-3

Sumary

$4-5$

$4-7$

Evaluation of Existing Documents

4-11

Commerclalization Sequence

4-19

Progress Mon1toring Features

4-21

Proposed Monftoring System

A-1

APPENDIX A - Plenary Session

APFENDIX B - Participants at the Geothermal Commercialization B-1 Workshop 
Figure Number

Page

$\begin{array}{lll}1-1 & \text { Direct Heat Use } & 1-96\end{array}$

1-2 Methodology - Direct Heat Use - API 1-97

1-3 Methodology - Direct Heat Use - EGG-UURI 1-98

1-4 Methodology - Electric Power 1-99

2-1 Atlantic City Residential and Comercial 2-25 Space and Eot Water

2-2 Gross and Net Savings by Year 2-35

3-1 Information Flows in "Scenario" Type 3-12

Commerclalization Aids

3B-1 Regional Planning Scenarios $3 B-62$

3B-2 Planning Scenarios 3B-63

3B-3 Site Prospectus Locations 3B-64

3B-4 Locations Having Implementation Plans 3B-65

4-1 Surface Exploration 4-13

4-2 Surface Exploration Sequence 4-14

4-3 Field Development Sequence 4-15

4-4 Ut111zation Sequence 4-16

4-5 Lease and Pemit Tracking 4-17

4-6 Progress Monitoring Data Elow 4-25 


\section{LIST OF TABLES}

Table Number

Page

$1-I$

Attachment 1 - Steps in Geothermal

$1-11$

Resource Commercialization

I-II

Attachment 2 - Direct Applications Commer-

$1-15$ cialization Matrix

1-III Attachment 3 - Electric Applications Act1- 1-19 vitles Matrix

Attachment 4 - Market Analysis Matr1x Example

$1-23$

$1-\nabla$

International Geothermal Financing Since

$1-111$ 1972 in Developing Countries

$2-I$

Ranking of Identified Research Needs in

$2-7$ Economics

Scenario Catalogue

$3 B-I$

Sumary and Evaluation of Planning

$3 B-5 \& 7$ Documents by Region

3B-II Scenario Evaluation

$3 B-17$

3B-III Scenario Evaluation

$3 B-21$

3B-IV Scenario Evaluation

$3 B-26$

3B-V Scenario Evaluation

$3 B-33$

3B-VI Scenario Evaluation

$3 B-37$

3B-VII Scenario Evaluation

$3 B-44$

3B-VIII Scenar1o Evaluation

$3 B-46$

3B-IX Scenario Evaluation

$3 B-48$

3B-X Scenario Evaluation

$3 B-52$

3B-XI Scenarto Evaluation

$3 B-54$ 


\section{LIST OF TABLES CONT'D}

Table Number

Page

3B-XII Scenario Evaluation 3B-56

3B-XIII Scenar1o Evaluation 3B-58

3B-XIV Key to Maps Wh1ch Show Scenar10 Coverage 3B-59

3C-I List of Finished or to be Completed-Planning 3C-6 or Strawman Scenarios Planning, or Strawman Effort

3C-II List of Finished or to be Completed - Site 3C-7 Prospectus or Geothermal S1te Schedule

3C-III Planning Scenarios 3C-8

3C-IV Market Assessments 3C-9

3C-V Site Prospectus $3 C-10$

3C-VI Geothermal site schedule 3C-11

4-I Sources of Information 4-18

4-II Progress Monitoring Options 4-20

4-III Selected Approach to Progress Monitoring 4-24 
LIST OF ACRONIMS

Acronym

$A E$

$A / E$

$A F B$

AIA

APL/JEU

ASERAE

ASTM

DGE

DOD

DOE

EDA

EPA

ERDA

ESL/UURI

ET

GLGP

GRC

GRIPS

GRMO

HUD

IBRD

IEDP

INEL

IRAC

JPL

LBL

LDC

MIT

NCSI

NEPA

OIT

PON's

PRDA's

RA

RMBER

SAI

SDC

TA

UIPA

UNDP

USDA

VA
Definition

Agricultural Engineer

Architect Engineer

Air Force Base

American Institute of Architects

Applled Physics Laboratory, John Eopkins University

American Society of Heating, Refrigeration and Air

Cond1tioning Engineers

American Soclety of Testing and Materials

Division of Geothermal Energy

Department of Defense

Department of Energy

Economics Development Administration

Environmental Protection Act

Energy Research and Development Agency

Earth Science Laboratory/University of Utah

Research Institute

Energy Technology

Geothermal Loan Guarantee Program

Geothermal Resource Council

Geothermal Resource Impact Projection Studies

Geothermal Resource Managers office

Eousing and Urban Development

International Bank for Reconstruction Development

International Energy Development Program

Idaho National Engineering Laboratory

Intermediate Risk Assuming Company

Jet Propulsion Laboratory

Lawrence Berkeley Laboratory

Lesser Developed Countries

Massachusets Institute of Technology

National Conference of State Legislatures

National Environmental Protection Act

Oregon Institute of Technology

Program Opportunities Notices

Program Research and Development Announcements

Resource Application

Rocky Mountain Basin and Range

Science Applications Institute

System Development Corporation

Technical Assistance

United Indias Planners Association

United Nations Development Programme

Unfted States Department of Agriculture

Veterans Administration 
SUMMARY

A two week geothermal commercialization workshop (29 January 9 February 1979) convened by Rudolph A. Black, the Department of Energy's (DOE) Geothermal Resource Manager, was held at The MITRE Corporation facility in McLean, Virginia. The purpose of the workshop was to systematically evaluate, for thelr applicability to geothermal commercialization needs, past efforts for DOE (and its predecessor, the Energy Research and Development Agency (ERDA)) in the areas of scenario generation and analysis, economics, marketing, and progress monttoring.

The participants came from DOE offlces and laboratories and non-profit contractors. The attendees were divided into four workIng committees: Marketing and Outreach; Economics; Scenarios; and Progress Monitoring.

Each committee performed the following specific tasks with respect to its area of concern:

1. Formulated objectives and roles for itself;

2. Reviewed current and completed Division of Geothermal Energy (DGE) * and other studies for aspects applicable to hydrothermal comerclalization; and

3. Identified significant areas of work in which efforts might be undertaken to assist in commercializing hydrothermal energy.

\footnotetext{
* The Geothermal Resource Manager's Office (GRMO) and its staff were largely drawn from the Division of Geothermal Energy (DGE). DGE had sponsored the work under review in this workshop.
} 
MARKETING AND OUTREACH COMMTTTEE

The objectives of this group were to: discuss ongoing DOE commercialization efforts; identify commercialization needs; and define steps required to commercialize the hydrothermal resource.

The three major activity areas which support the Federal role in commerclalizing energy are:

1. Define the technology required to exploit the full extent of the resource;

2. Perform market analyses to define the market, determine the economic position, assess the potential for market penetration, identify the barriers, address financing problems, and develop the market strategy. Concurrently, identify market sector needs required to support the projected growth, e.g., capital sources for different phases of development; and

3. Market preparation/marketing.

The committee then developed commercialization matrices for direct utilization and for electric applications. The matrices correlate the main elements of commercialization actions to the known DGE contractors and programs that are applicable to commercialization. These matrices give an unquantified perspective of the level of activity that is already going on in the commerclalization arena.

The marketing committee reviewed and analyzed 28 study documents. These analyses provided information of past and current work relating to the commercialization of hydrothermal energy, and allowed the committee to examine the quality of present output and the future-needs for commercialization. 
The areas which require more thorough evaluation to meet future needs for commercialization are:

1. National market analysis and penetration strategies;

2. Resource information and development;

3. Resolution of capital shortage and high investment risk problems;

4. More flexible leasing and regulatory policies;

5. Technical assistance and information;

6. Accelerated site-feastbility screening;

7. More timely and higher quality field demonstration projects;

8. Industrial energy-use intelligence and executive commitments ;

9. Community heating systems (brokered help);

10. Direct application market stimulation - public buildings;

11. Electricity market stimulation;

12. General public information;

13. Technology specification review;

14. Environmental baseline data requirements;

15. Techno-structure analysis (technical super-structure: e.g., availability of adequate numbers of drilling rigs, reservolr engineers, etc.);

16. Market data base and market monotor;

The committee then developed the following recommended methodology for market definition : 
1. Define geothermal resources - quality, location and areal extent;

2. Screen potential users;

3. Overlay resource locations and potential user locations to establish colocation feasibility;

4. Analyze markets in four use sectors: (a) Industrial, (b) Residential/Commercial, (c) Military/Federal Facilities, and (d) Agricultural.

The group defined the product of marketing to be the concept of using geothermal energy for all types of applications with replacement potential. DOE's role would be similar to that of a marriage broker, matching user with resource.

The marketing committee also evaluated marketing activities pertaining to lesser developed countries (LDC's). It was recommended that, pending closer definition of market opportunities among LDC's for recently developed U.S. geothermal technologies, international activities can be used strategically to support the broader DOE/RA commercialization objectives of geothermal industrial infrastructure development.

\section{ECONOMICS COMMTTTEE}

The objectives of the Economics Committee were to:

1. Establish the current status of economics knowledge as it pertains to the commercialization of hydrothermal resources;

2. Identify gaps in knowledge and recommend action needed to support commercialization; and

3. Describe the role of economics in the commercialization process. 
Economic studies will be used to support marketing in two basic areas: 1) Generic studies performed as a function of generalized resource parameters and financial characteristics; and 2) Sitespecific studies performed for a specific resource and with financial characteristics appropriate for a specific developer and/or utility or other user.

Twenty-four documents were analyzed with respect to research results and their relevance to commercialization.

The committee concluded that there is a good basis for commercialization for electric generation; there is an incomplete basis for commercialization for non-electric usage; and most of the completed studies are resource-oriented.

The committee ranked the Identified research needs in Economics:

\section{High Priority Items}

1. Risk and rellabllity analyses

2. Cost benefit analyses related to R\&D programs

3. Market penetration models

4. Market penetration analyses

5. Systematic studies of non-price market factors Intermediate Priority Items

6. Site-specific industry studies

7. Systematic comparisons or standardization of economic analyses 
8. Studies of export market potential for geothermal technology

9. Updating and refinement of production cost models

10. Economic analyses of environmental control costs and systems

11. Analyses of barriers to market entry and expansion

12. Development of better risk and reliability models

13. Updating supply curves and sensitivity analysis for major uncertainties

\section{Low Priority Items}

14. Regional economics analyses

15. Development of marketing games

16. Infrastructure analyses

17. Cost benefit analyses from the social welfare standpoint

18. Venture analyses

19. Development of better demand models

20. Generic demand analyses

21. Economic studies of technology transfer to less developed countries

22. Development of new production cost models

23. Additional net energy analysis

\section{SCENARIO COMMITTEE}

The committee reviewed and evaluated, in terms of their contribution to commercialization support needs, 23 studies which have been done on geothermal electric and direct application scenarios (development plans). 
The five general types of scenarios used to date as planning and marketing tools for geothermal energy are: market-resource assessment (areawide broad-brush); planning scenario (including general development schedules); site prospectus (detailed treatment of resource, demographics, users, etc.); detailed geothermal site schedule (including computer-assisted scheduling); and programatic implementation plan.

The market assessment studies have been completed for some regions, However, aggregated national and reglonal studies are . needed. The planning scenarlos are generally adequate but existing scenarios need to be updated and refined. The site prospectus type of scenario is needed for all major sites; this would require extensive interaction among Federal, state, local and private sectors. (The Colorado geothermal development scenario is a good example of a site prospectus,) The site schedules have been developed for most major electric sites, with many examples available. Since there is considerable variation in detail, there is a need to revise and update these schedules. The implementation plans are useful as a marketing tool. The format of the plans should be developed carefully and the site schedule should provide the basis for each plan. The group recommended that DOE should further discuss whether the commissioning of future work should be linked to the degree of commitment evidenced by the private sector, and whether the private sector's commitments to develop specific sites should be tracked. 
Whatever the decision, the plans should be drawn up in enough detail to permit forward planning by Federal and state agencies to provide the necessary permitting, regulatory, and other enabling support to developers.

The group endorsed a recommendation that user-oriented develop= ment scenarios be commissioned to complement the resource-spectific scenarlos which were being evaluated. Whereas the resource scenarios may have been adequate for planning an R\&D and incentives program, the systematic addition of potential user information is required to support a commercialization program.

Finally, it was recommended that the individual problems or unresolved issues, which surfaced during the devlopment of the planning scenarios and the site prospectuses, be collected, distilled, and either acted upon by DOE or shelved.

One member of the committee presented strong arguments for developing site prospectuses as tools for commercialization. He stressed the value of involving local interests in the generating of site prospectuses.

The still spotty coverage of the eastern part of the country by planning scenarios was reemphasized. The group recommended that direct use application scenarios in the eastern U.S. be given increased attention. 
1. Concise state-by-state summary of the status of geothermal development. This enables executives to keep abreast of very general progress in states or resource areas;

2. Periodic listings of development highlights within a region. These enable executives to have many important and specific data svailable.

3. Computer-supported systems for listing specific scenarios (site specific or somewhat more generic).

The proposed monitoring system would use already existing state teams for additlonal planning and outreach functions, and for frequent reports to DOE. Some states, which have limited identified resources, would use a "circuit rider" to contact a group of states to update a baseline document semi-annually. A baseline report is essential for every state with numerous resources and possibly on a DOE-region basis for all other states.

The baseline data report should include: Basic state data: hydrothermal resources; Commerclalization activities: Leasing, permitting, Historical highlights, Operational systems (power on IIne); Exlsting scenarios; Government assisted activities; Energy use patterns; and Leasing and permitting.

The approach proposed should produce a significant amount of progress monitoring data for a reasonable cost and has the benefit of Involving the state teams already working on commercialization activities in the field. The system will provide the bulk of information needed to evaluate the DOE commerclalization thrust, and provide a basis for market penetration analyses and progress planning. 


\section{PROGRESS MONITORING COMMITTEE}

The objectives of this group were to:

1. Determine the need for and requirements of progress monitoring activities;

2. Determine where data can be obtained, and how it should be collected, processed, and distributed; and

3. Determine what data processing systems are needed, and how much the monitoring process might cost.

Progress monitoring is necessary for the following reasons:

to provide input to program planning; to measure program effectiveness; to support public awareness; and to support PL $93-410$ reporting requirements.

The approach selected by the committee for conducting this assessment is: Review existing documents; Determine the need for progress monitoring; Determine the requirements for progress monitoring (essential and desirable); Identify data sources, determine the collection process, and the methods for data processing systems; and recommend a plan for national progress monitoring. :

The committee reviewed eight documents to determine the proposed scope of monitoring, the utility of each approach, and the apparent limitations for progress monitoring.

The reviewed documents were interpreted with reference to the features established as desirable for a progress monitoring system. Three generic types of potential monitoring now exist: 
MARKETING AND OUTREACH :

SECTION 1

$1-1$ 


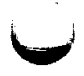




\section{MARKETING COMMITTEE}

(WORK COMPLETION NOTES)

The subcommittee on Marketing, for the Geothermal Resource Office, Commercialization Task Force, was formed Monday, January 29, 1979. Participants were:
R.J. Schultz
L.D. Mann

R.C. Stephens*

W.J. Toth

W. Yen

M.W. Molloy*

T.C. Gardner

R. Gerson

v. Wheaton*

R. Lease

S. Sellars

W.D. Gentsch

E. Peterson*

B. Barns*

Y. Nakamura
Cha1rman, EG\&G/INEL

Department of Energy, Regional

Representative Office, Seattle (DOE)

Department of Energy Resource

Managers Office (DOE)

Applied Physics Laboratory/John

Hopkins University (APL/JHU)

Lawrence Berkley Laboratory (LBL)

Department of Energy, San Francisco

Earl Warren Legal Institute

Department of Energy Resource

Managers Office (DOE)

The Futures Group

Department of Energy, Idaho (1st Week) (DOE)

Department of Energy, Office of Regional Representatives, (1st Week)

EG\&G/INEL

Department of Energy Resource Managers Office (DOE)

Department of Energy Resource Managers Office (DOE)

Jet Propulsion Laboratory (2nd Week) (JPL)

* Part-Time 

SUMMARY

The first day and one half to two days were spent discussing the ongoing DOE commerclalization efforts and defining the steps required to commercialize the hydrothermal resource.

Four major steps and many substeps were agreed upon by the committee, These steps are:

(a) Define the technology requirements necessary to exploit the full extent of the resource,

(b) Perform market analysis to define the market, determine the economic position, assess the potentlal for market penetration, identify the barriers, address financing problems and develop the market strategy. Identify market sector needs, required to support the profect growth, e.g., capital markets for the different phases of the development;

(c) Prepare and develop the market and;

(d) Perform the actual marketing.

These elements are summarized in Attachment 1. The marketing elements were expanded during later meetings and the market preparation activities were merged with the marketing activities,

The next activity was the development of both direct applications and electric applications; Commercialization Activities Matrices. These matrices, presented as Attachments 2 and 3 , respectively, present the elements of commerclalization and the known geothermal contractors and programs which have applicable commercialization. The matrices were developed to give the committee an unquantified perspective of the amount of activity which is actually going on in 
the commercialization arena.

An example matrix was also developed which, if completed in detail, will further define the status of commercialization levels in the current DOE program. The example matrix is included as Attachment 4 .

The committee next developed a "Major Needs" 1ist. It was felt by the committee that these needs should be satisfied by programs, projects or legislation if satisfactory comnercialization was to be obtained. This list is presented as Attachment 5.

An applicable "Documents List" was developed by the group. Neither availability of the documents nor time allowed for critique of these documents. The list is enclosed as Attachment 6 .

At this point, the committee became aware that the complete commercialization effort could not be addressed in the time allotted. Therefore, their attention was focused upon the "Marketing" or outreach functions of the steps in commercialization. Summaries presenting the current program for each of the seven "Marketing" elements were developed and reviewed by the committee. The seven market elements are (a) Technical Assistance, (b) Special Projects, (c) Brokering, (d) State Policy Review, (e) Public Information, (f) Workshops, Symposia and conferences, and (g) Financial Incentives. The summaries Include a description of the existing program, significance of the program, results of past activities and a general evaluation of the program. These summaries are included as Attachment 7. 
The committee next addressed what the "Ideal" program for each of the seven elements should consist of. These descriptions are included as Attachment 8. The description also identifies which of the "Needs" from the Major Needs list are dealt with.

Per request of the Resource Manager, an evaluation was made by a marketing subcomittee concerning the methodology for Market Definition. This evaluation is presented as Attachment 9.

A second evaluation was made by request. This evaluation addressed marketing activities as pertaining to the Lesser Developed Countries. This evaluation is presented as Attachment 10.

It should be noted that the information contained herein was not obtained entirely by consensus. Strong feeling by a single member of the team was impetus enough to cause inclusion in the text of the marketing committee report. Nor did the chairman reserve the right to edit out material not consistent with his marketing approach. 


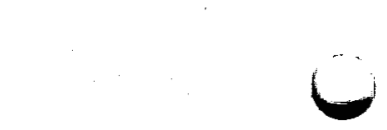




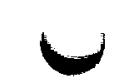

ATTACHMENT 1

STEPS IN GEOTHERMAL RESOURCE COMMERCIALIZATION

1-9 
TABLE 1-I

STEPS IN GEOTHERMAL RESOURCE COMERCIALIZATION

\begin{tabular}{|c|c|c|}
\hline $\begin{array}{l}\text { ET DEVELOPMENT } \\
\text { REQUIREMENTS }\end{array}$ & $\begin{array}{l}\text { MARKETING } \\
\text { ANALYSES }\end{array}$ & $\begin{array}{l}\text { MARKET PREPARATION } \\
\& \text { MARKETING }\end{array}$ \\
\hline $\begin{array}{l}\text { - Resource exploration } \\
\text { (Temp, depth, location) } \\
\text { - Resource assessment } \\
\text { (how big, lifetime) } \\
\text { - Resource engineering } \\
\text { (how best to use) } \\
\text { - Special technologies } \\
\text { new pumps } \\
\text { materials } \\
\text { methods of handling } \\
\text { storage \& transmission }\end{array}$ & $\begin{array}{l}\text { 1. Market Definition } \\
\text { Particular usage types } \\
\text { Sizes of market } \\
\text { Location with respect } \\
\text { to resource } \\
\text { Density of users } \\
\text { Engineering feasibility } \\
\text { PRDA } \\
\text { 2. Economic analyses } \\
\text { Wellhead costs } \\
\text { Delivered costs } \\
\text { Effects of incentives } \\
\text { Cost/benefit analyses } \\
\text { PRDA } \\
\text { 3. Market penetration } \\
\text { Cost of competitors } \\
\text { Value of special attributes } \\
\text { Effects of fuels availabilities } \\
\text { Penetration analyses } \\
\text { 4. Identification of barriers } \\
\text { Environmental constraints } \\
\text { Legal barriers } \\
\text { Institutional factors } \\
\text { Technical limit } \\
\text { Financing problems } \\
\text { 5evelop marketing strategies } \\
\text { Venture-cost/benefit } \\
\text { Scenario development }\end{array}$ & $\begin{array}{l}\text { 1. Technical Assistance } \\
\text { 2. Public information } \\
\text { 3. Financial incentives } \\
\text { 4. Brokering } \\
\text { 5. State and local } \\
\text { policy review } \\
\text { 6. Special programs } \\
\text { 7. Workshops, symposiums, } \\
\text { and conferences. }\end{array}$ \\
\hline
\end{tabular}



ATTACEMENT 2

DIRECT APPLICATIONS COMMERCIALIZATION MATRIX 
, 
raber 1-3I

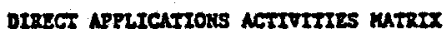

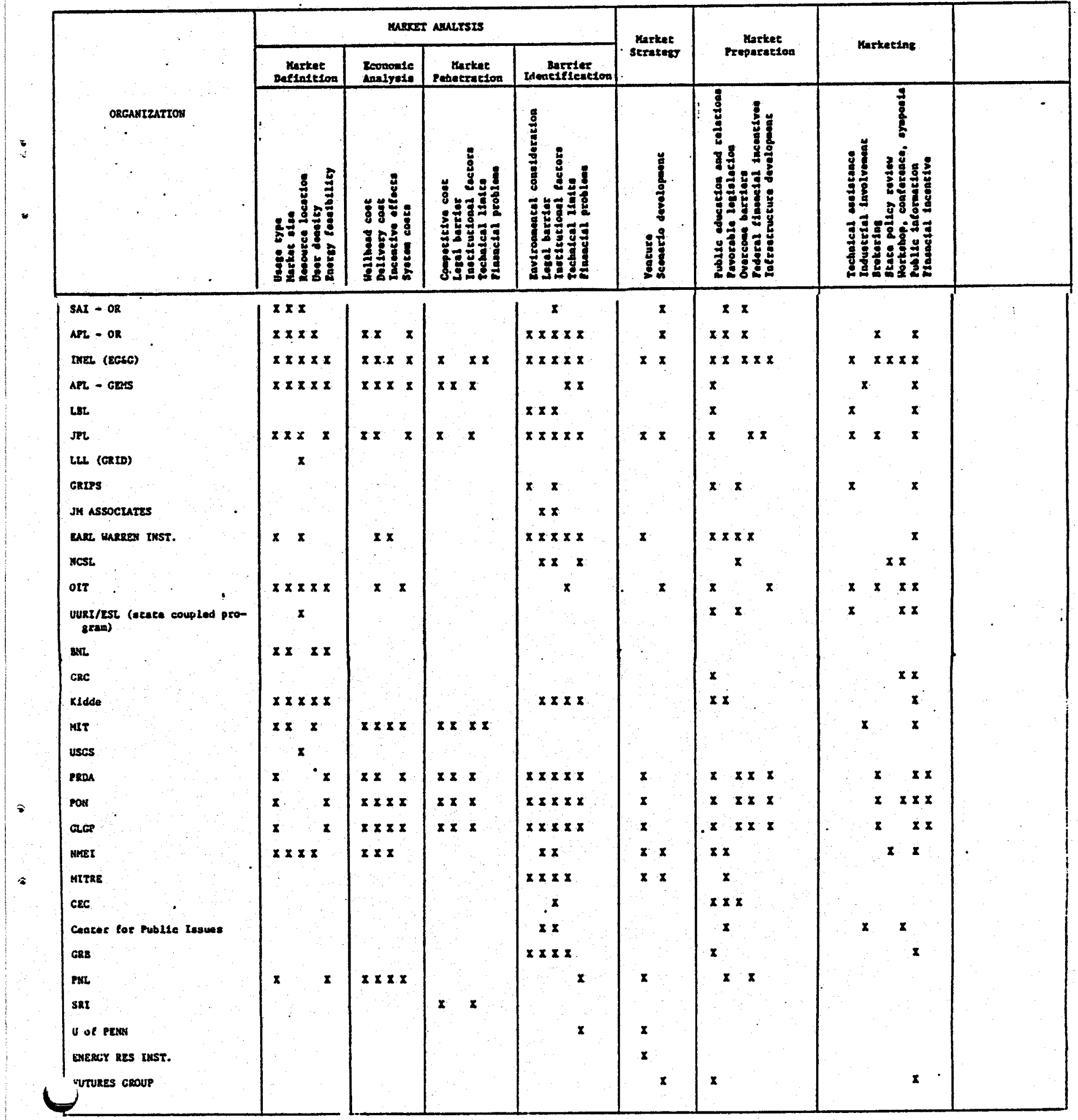




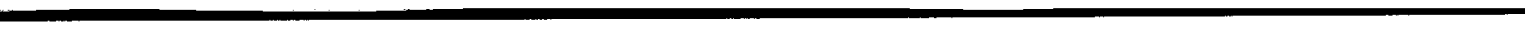


ATTACHMENT 3

ELECTRIC APPLICATIONS COMRERCIALIZATION MATRIX 
TABLE 1-IIT

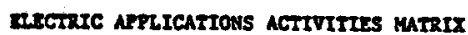

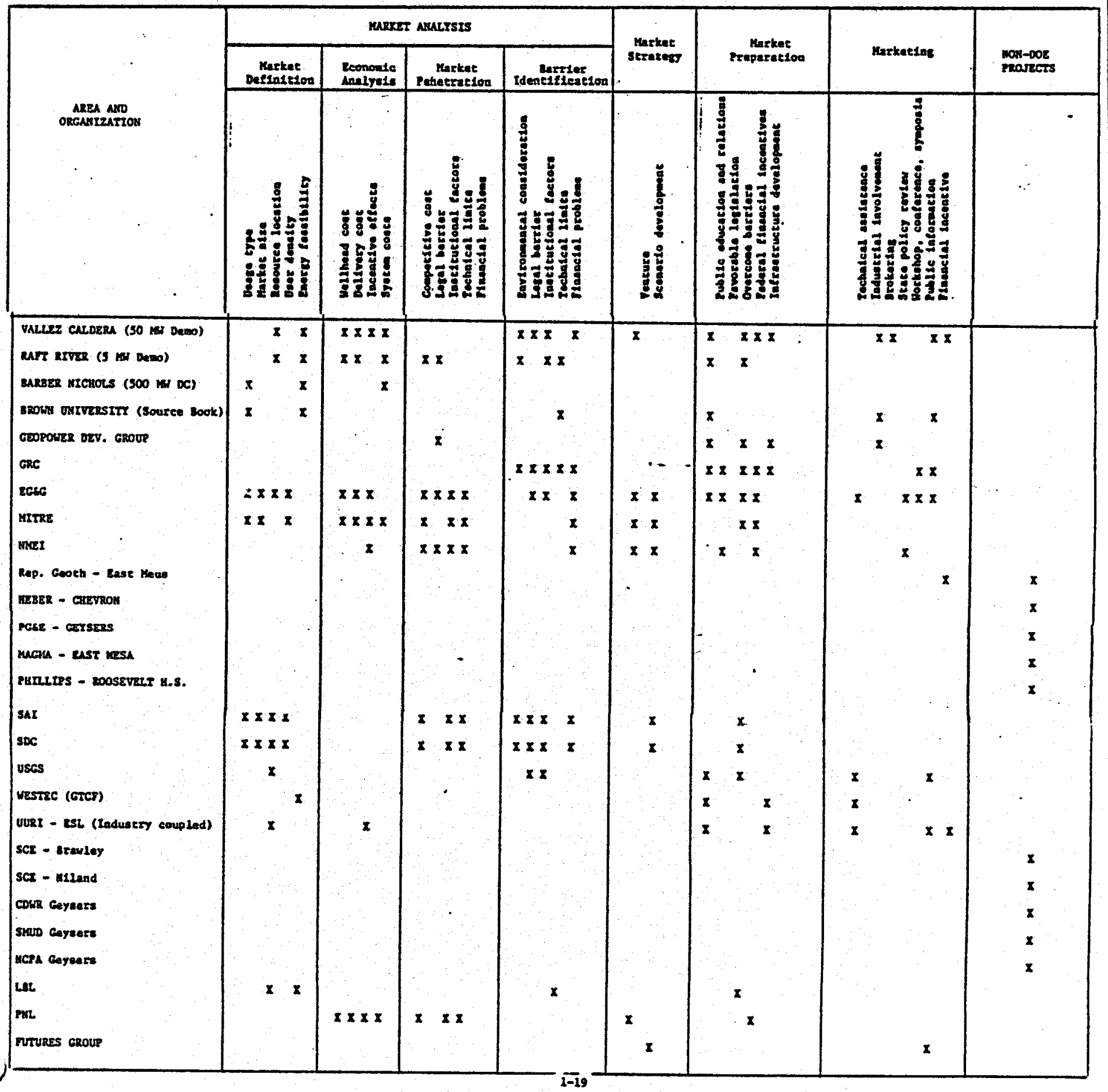




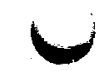

ATTACHMENT 4

\section{MARKET ANALYSIS MATRIX - EXAMPLE}

$1-21$ 

Luns 1-IV

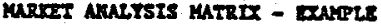

\begin{tabular}{|c|c|c|c|c|c|c|c|c|c|c|c|c|c|c|c|c|}
\hline $\begin{array}{l}\text { MAR } \\
S E\end{array}$ & & $\begin{array}{l}\text { Marestme } \\
\text { roots }\end{array}$ & 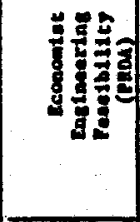 & 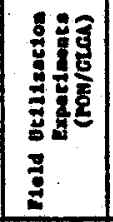 & 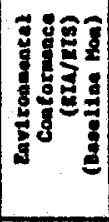 & 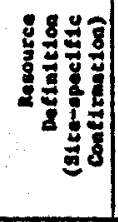 & 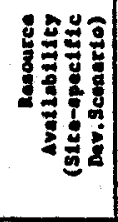 & 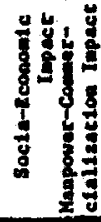 & 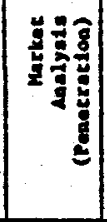 & 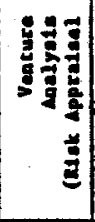 & 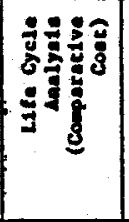 & 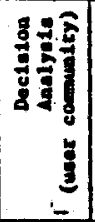 & 象总 & 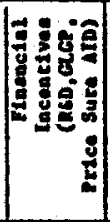 & 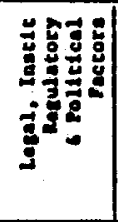 & 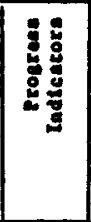 \\
\hline & $\operatorname{sect}$ & OR/APPLICATTOH & $\boldsymbol{A}$ & $\mathbf{s}$ & c & D & $\mathbf{z}$ & $\boldsymbol{r}$ & 6 & a & I & $J$ & $\boldsymbol{x}$ & b & $\boldsymbol{H}$ & 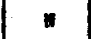 \\
\hline 章 & 2 & $\begin{array}{l}\text { Pood Processing } \\
11 \text { Potatois } \\
.2 \text { OaLons } \\
\text { Mgeral Benefleis- } \\
\text { ton }\end{array}$ & $\mid \begin{array}{l}:-1 \cdot|-A|+2 \\
|-2 \cdot-A|+2\end{array}$ & $\begin{array}{l}I-1.1-8 \\
I-1.26\end{array}$ & $\begin{array}{l}t-1.1-C \\
I-1.20\end{array}$ & $\begin{array}{l}I-1.1 .1 \\
I-1.28+0\end{array}$ & $\begin{array}{l}1-1.1-8 \\
1-1.2-8\end{array}$ & & $\begin{array}{l}1.1 .1-6 \\
-1.1\end{array}$ & $\begin{array}{c}t=1 . t \\
-A 1+2 \\
t-1.11\end{array}$ & $\underset{1-1+2.1-1}{11+2}$ & $\begin{array}{c}I-1.1-3 \\
I-1.2 \\
I-2-12\end{array} \mid$ & $\mid \begin{array}{l}2-1.1 \\
-8 \\
-2-12\end{array}$ & $\begin{array}{l}I-1.1-2 \\
I-1.2 \mathrm{I}\end{array}$ & $\underset{n l+2}{1-1.1}$ & 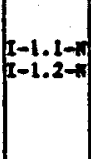 \\
\hline 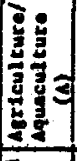 & 2 & 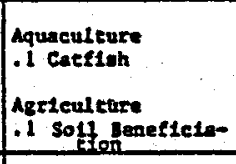 & $\mid 1-1.1-\alpha$ & $\mid \begin{array}{c}A-1.1-1 \\
x+2\end{array}$ & $\mid \begin{array}{r}1-1.1 \\
c 1+2\end{array}$ & 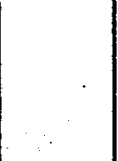 & & • & & $\int_{1+1}^{1.1-3}$ & $A 1.1-82+2$ & A2.1 $=1$ & $\underset{12}{1-1.1}$ & & ${ }_{k 1+2}^{+21.1}$ & $\begin{array}{l}x .1 \\
n t+2\end{array}$ \\
\hline 룽 & 1 & 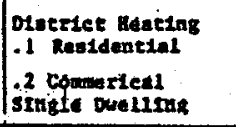 & 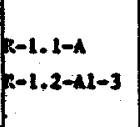 & $\begin{array}{l}x-1.1- \\
x-3 \\
k-1.2-3 \\
A-3\end{array}$ & $\begin{array}{l}n-t, 1-c \\
n-1,2-6\end{array}$ & $\begin{array}{c}2-1.1-1 \\
82-5 \\
21.2-32-9\end{array} \mid$ & & & $\mid \begin{array}{l}2-1.1-6 \\
\mathrm{k} .201-1\end{array}$ & $\left\{\begin{array}{l}-1.1- \\
1-5 \\
1.2- \\
1-9\end{array}\right.$ & \begin{tabular}{|l|}
$k-1.1-8 t-5$ \\
$k 1.2$
\end{tabular} & & & & $\begin{array}{l}2-1.1- \\
12-5 \\
21.2-1-1-6 \\
12-2-4\end{array}$ & $\left\{\begin{array}{l}21.1-x \\
21.2-x\end{array}\right.$ \\
\hline$\frac{1}{3}$ & $\begin{array}{l}1 \\
2 \\
3 \\
4 \\
3\end{array}$ & $\begin{array}{l}\text { Municlpal } \\
\text { Publie ottuty } \\
\text { Coop } \\
\text { Capte1ve Vee } \\
\text { Cogeneration }\end{array}$ & & $\begin{array}{l}0-1=2-1 \\
02,31+2 \\
03 B\end{array}$ & $\mid \begin{array}{l}0-2-c \\
A 1.1 \text { c.2 }\end{array}$ & $1-2 \times 2+2$ & $0-2-8$ & & $\mid-1.1-6$ & $0-18$ & $\begin{array}{l}0-18 \\
12-82+02 B\end{array}$ & $\begin{array}{l}0-18 \\
0240282\end{array}$ & & $\mid \begin{array}{ll}p-2-3 \\
02 & 31+2 \\
038\end{array}$ & $128+028$ & $02 \mathrm{~nL}+$ \\
\hline
\end{tabular}

$I=1.1-1$

$1-1.1-1$

$t=1.1-8$

$1-1.1-6$

$1-1.1-6$

$I=1.1-K$

$1=1.1-4$

$1-1.2-1$

$1-1.2-c$

$-1.2-0$

$1=1.2-1$

$t=1.2-11$

$1-2 .-11$

$I-2,-12$

$2-1+1-c$

a $=1.2-1$

$2-1.2-1$

$=1.2-1$

$-1.2+n$

R $-1.2-6$

$1.2-02$
$-1.2-63$

- 1.2-31

R $-12 .-12$

2- 1.2-13

a $-1.2-8$

R $-1.2-1.5$

$\mathrm{R}=1.2+86$

2. 1.2-18
Pena - ort \& oretor woons 1977

tagtnearing tral, Total Use Coocept, Dugh 1976

poN - Oreide poods - 197

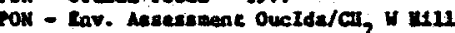

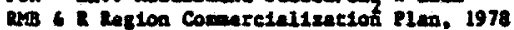

MAB I I tegion Dreft Ponetracion anelfete, 1978

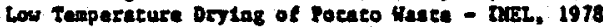

Orelda Foods Honebly Erogreas Reports

Goocherms1 Toods Processors - Ogerating Pac1115y - GOP buckad

ORNR - zIL tor brady boe spes of process

GPP - Easoures deftnition Ppt.

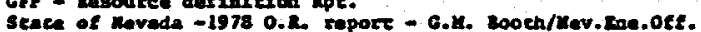
GT - Loan Appltescton

GFP - GLOP - Prosress Payenc lpt.

Receal - Trace Dise 148 seudy

C1ty of turbank, Stoudy, Coel Banfieution

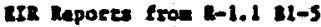

Hoochly Apes.

Idgemont Sehool Blatrter

Splce Heactag of 10 scate lusldings, mor. 1976

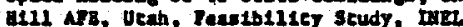

Pederal Focllity Gross Mateh tvaluntion, twr

cast Cone svaluition - APL

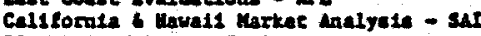

PON, Ruch Rulaweth ralle

rox, radison County

PON. Clty of suranvile

Pox, Poyoen Springs, Colorado

PON, Douglas School, South Dakota
$1-1-1$

$a-1.1-81$

$A-1.1-82$

$A-1.1-61$

$1-1.1-62$

A - 1.1-

$4-1.1+11$

A $-1.1-1+12$

$2-1.1-31$

t. $1.1-1-1$

$2-1.1-31$

10 - 1.1-it

R - 1.1-1

$R-1.1-84$
$-1.1-85$

- $-1.1-12$

\section{- Ixcectar specear}

T - 1.2-88

$-1.8-19$

1. $1.2-8$

a $=1.2-1$

$0-2 .-1$
$0-1 .-21$

$0-2 .-1$

$0-2 .-12$

$B-2-c$

$0=2 .-5$

$v-2 .-12$

$0-3 \cdot-8$
$4-2-11$

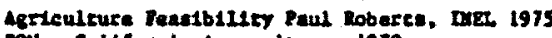

PON - Cellfornte Aquaculture, 1978

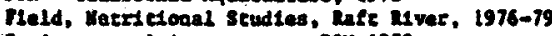

Envtronmencal desessisane - pow 1979

Iavirondencal Iapace Stacement, Raft River, 1977

Pay. Erivace Developmenc

Pod - ronchly Rapote

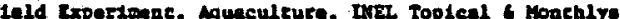

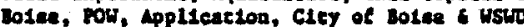

Prou - OIT, Rulawueh Falls, ore.

Pad - 81ko Moveda

Mdiend Souch Dakoea, Privace Developsene

Honcos cary, Vear, pon

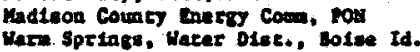

Pod. Sc. Menges Hospitel

THS Hoxpteal, Varlin Texas

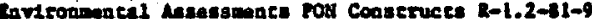

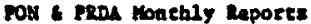

Frivats Masdence, Kulamuch Fallo Der.

GeP- CIty of turbank (GLF withdrawn)

public survice of the Hextco - 50 ist oemo

ters - Gayens:

ctu tor $0=2-8 t+2$

84T/SDC Callforn1e developmant scenartos

Frograss Payment Raports for MCPL - CLO

Honthly Progress Repores - $50 \mathrm{kt}$ Deso

Geochermal Power Developienc Group (Rafe tuver ste Operacton)

Factlte Gas \& Blectic (Geyerre) 

ATTACHMENT 5

NEEDS ASSESSMENT FOR COMMERCIALIZATION 

NEEDS ASSESSMENT FOR COMMERCIALIZATION

1. National Market Analysis \& Penetration Strategies.

2. Resource information \& development.

3. Resolution of capital shortage \& high investment risk problem.

4. More flextble leasing \& regulatory policies.

5. Technical assistance \& Information.

6. Accelerated site feasibllity screening (PRDA).

7. More timely \& higher quality field demonstrations.

8. Industrial energy use Intelligence \& executive commitments.

9. Commity heating assistance (broker).

10. Direct application market stimulation - public buildings.

11. Electricity market stimulation.

12. General public information.

13. Technology specification review.

14. Environmental baseline data requirements.

15. Technostructure analysis.

16. Marketing data base \& monitor.

A description of each of the "Needs" is presented in the following section. 
Needs Assessment for Commercialization

1. National Market Analysis and Penetration Strategies

Market analyses need to be made on a regional basis (aggregated eventually to a national market picture) identifying market sectors particularly attractive for retrofit and/or expansion based on hydrothermal energy. Econometric analyses of market penetration rates with respect to competitive fuels needs to be undertaken and strategies developed to achleve penetration possibilities.

2. Resource Information and Development

Greater knowledge needs to be developed concerning the extent and economic potential of hydrothermal resources particularly those suited for direct thermal applications. More resource development needs to be undertaken and greater efforts expended to convey the results of this resource development program to the public at large and to the potential users.

3. Resolution of Capital Shortage and High Investment Risk Problem Continuing examination needs to be conducted on the competitive position of geothermal energy in the national capital market. Even with the recently enacted NEA, dozens of examples, exist where potential project developers are unable to obtain needed financing to undertake their projects, particularly moderate size projects involving direct thermal applications. The Federal Loan Guaranty program needs to be evaluated with respect to its potential for encouraging direct thermal applications. As it stands, application procedures and costs, tend not to be worth the effort for smaller project developers.

4. More Flexible Leasing and Regulatory Policies

Overlapping state and federal regulatory policies including drilling, environmental impact reviews, bonding and other permitting requirements act as deterrents to project development. 
More flexdble leasing policies might be considered particularly with respect to increasing the maximum and lowering the minimum allowable under federal leasing statutes. This is particularly true for smaller scale direct thermal applications which may require property of 50-100 acres.

5. Technical Assistance and Information

User assistance provided to potential project developers is a relatively low-cost, high-payoff program where basic information is provided to assist developers in evaluating the potential of their proposed projects. The public information program incorporating displays, brochures, films, and presentations to particular user groups, can all help prepare the market for an earlier commerclalization of hydrothermal energy.

6. Accelerated Site Feasibility Screening The PRDA program might be reevaluated with a view towards fundIng a greater number of studies with a lower maximum fund ceiling, perhaps cost-shared. This would allow a greater number of potential hydrothermal resource sites to be evaluated on their comercial potential.

7. More TImely and Higher Quality Field Demonstration Projects As opposed to its periodic solicitation of proposals for field demonstration programs, the DOE should consider the value of an open-ended solicitation program for field demonstrations. Such a solicitation program, unbounded by the 90-day requirement, would provide more carefully prepared project proposals and potentially more beneficlal fleld demonstration projects.

8. Industrial Energy Use Intelligence and Executive Commitments The MIT Industrial Energy Use Program has Involved executives of the pulp and paper Industry regarding the potential for using hydrothermal energy in that particular industry. The program should be expanded perhaps including other contractors to reach a wider spectrum of Industry and executives involved 
in the energy concerns of that industry. Continuing studies need to be undertaken, preferably by or with the industries involved on the development of energy use intelligence for a broad spectrum of American enterprise. This program might be guided by the National market analysis work described above.

9. Community Heating Systems (Brokered Help) The DOE should place itself in the position of being able to provide assistance to community-wide heating projects by brokering assistance and cooperation from other federal agencies and their regional offices.

10. Direct Applications Market Stimulation-Public Buildings The identification of appropriate public buildings projects by the Department of Energy, for example, public health service and VA hospitals, national laboratories, and military installations, may provide a significant stimulation to hydrothermal energy development by the private sector in adjacent or adjoining residential or metropolitan areas. The expansion of public building programs, whether by the state or by the federal government, should be undertaken with the view towards stimulating the market for hydrothermal energy.

11. Electricity Market Stimulation

For higher temperature resources the commercialization of electric power production is probably self-sustaining. For moderate temperature hydrothermal fluids, however, the commercialization of electric energy produced from a binary cycle may require a significant interaction with regional utilities and conveying to them results of government-sponsored research activities (Raft River) and the economics of such power plants projected through the next 10 to 15 years.

12. Genera1 Public Information

Efforts should be made to convey to the general public the potential of hydrothermal energy in various applications to 
lessen the dependence of the United States on forelgn sources of fuels. These could be possible through the public school system, through colleges and universities, by county fairs and by media presentations.

\section{Technology Specification Review}

For hydrothermal commercialization to be a reality, a continuing assessment needs to be made of special research and development requirements to overcome technical obstacles to commerclalization.

\section{Environmenta1 Baseline Data Requirements}

Environmental permitting requirements may pose a significant block to widespread commerclalization of hydrothermal energy. The permitting process could be dramatically shortened, if state and federal agencies could commence environmental baseIne programs centered on the key hydrothermal resource regions of the United States.

15. Techno-Structure Analysis

An assessment should be commenced concerning the adequacy of the technical super-structure upon which the commercialization program must rest. The avallability, for example, of adequate numbers of drilling rigs, reservolr engineers, geologists and hydrologists, equipment vendors and $A E$ firms, may affect the rate of commercialization.

16. Marketing Data Base and Monitor

A national commercialization project montoring system must be devised and implemented to gauge the effectiveness and pace of the commercialization program. This monitoring system will include, but not be $11 \mathrm{mited}$ to the rate of projects on-1ine, leasing activity, drilling activity, and permits issued for the development of projects. 
$\mathcal{U}$

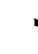


ATTACHMENT 6

DOCUMENTS LIST 
"Sumary Report, Southwest Regional Geothermal Operations Research Program", Western Energy Planners, LTD, AP-01-79.

Draft, "Regional Hydrothermal Market Penetration Analysis", Rocky Mountain Basin and Range RegIon", ID/EG\&G/ESL.

"Reglonal Hydrothermal Commerclalization Plan for the Rocky Mountain Basin and Range Region".

Final Report "Pacific Northwest Region Operations Research", OIT.

"The Market Structure of the Geothermal Industry and Incentives for Stimulating Geothermal Development", CONSAD.

"Near-Term Geothermal Energy Supply Curves and the Impact of Technology", PNL-2753.

Handbooks - Brown University

Geothermal Investment Analysis - University of Pennsylvania - Contract ET-78-S-02-4713.

Direct Utilization of Geothermal Energy: A Symposium; January 31 February 2, 1978, San Diego California, GRC April 1978, CONF 780133.

Small Business Participants in Geothermal Energy Development: Recommendations for the Geothermal Omnibus Bili, West Energy Planners \& EG\&G.

"Industry Survey for Direct Application and Small Scale Electric", LBL.

Draft "Commercialization Strategy Report for Hydrothermal Electric and Direct Heat" Task Force Report, TID 28840.

Total Use (Electric and Direct Heat) Scenarios for Imperial Valley Prospects - SAI.

"Utility Plans for Utilization of Geothermal Energy in California", JPL-5030-267.

PRDA - Final Report - Individual Contractors Sumary Report.

"Geothermal Energy Development in Colorado: Process, Promises and Problems" - Colorado Geological Survey, Department of National Resources, State of Colorado. 


\section{DOCUMENTS LIST (Cont.)}

"Pacific Region Federal Geothermal Commercialization Plan", Department of Energy, Division of Geothermal Energy, San Francisco Operations Office, 16 October, 1978, (Working draft).

User Manuals - GRC (in development), JPL: Direct Use Handbook.

"Analysis of Requirements for Accelerating the Development of Geothermal Energy Resources in California" Jet Propulsion Laboratory, publication 77-63, C.D. Fredrickson, November 15, 1977. 
COMMERCIALIZATION DOCUMENTS (NON ECONOMIC)

*Commerclalization of Geothermal Resources GRC Conference Report.

*Market Analysis for Geothermal Energy for California and Hawail, SAI-78-948-LG.

A Development Scenario for Geothermal Energy Development - the Eastern Gulf Coastal Plain (in preparation) JHU- Applied Physics Laboratory, APL/JHU QM-77-129-3.

Geothermal Energy Market Study - Atlantic Coastal Plain - APL.

A Development Scenario for Geothermal Energy Development - Atlantic Coastal Plain - APL/JUU. QM-79-129.

A Development Scenario for Geothermal Energy Development - Arkansas (Informal Report), APL/JHU QM-77-129-1.

Inventory and Case Studies of Louisiana Non Electric Industrial Applications of Geopressured Resources, de Lauraul Engineers, Inc., IDO/1629-L.

"A Market Survey of Geothermal Wellhead Power Generation Systems" JPL.

* Non DOE Sponsored. 

ATTACHMENT 7

CURRENT PROGRAM MARKETING SUMMARIES

$$
1-39
$$


$\mathcal{U}$

$=$ 


\section{TECHNICAL ASSISTANCE}

\section{Description}

User assistance is provided to both the public and private sectors to promote the acceptance and utilization of geothermal energy. Assistance is given to requestors in consultant format. Technical areas include reservolr definftion, geologic and hydrologic evaluation, utilization planning, conceptual design, design and specification review and operations evaluation. The support effort is ilmited to 100 hours of staff time per project on a first come, staff available basis. The current program includes OIT serving Alaska, Oregon and Washington in the engineering, materials and utllization aspects; LBL provides resource assistance in the pacific coastal states; EG\&G/INEL and UURI/ESL provides technical assistance in all of the above areas in the Rocky Mountain Basin and Range states (RMB\&R). In addition, the state geologic and planning/outreach teams have been trained to help provide this service in their area. APL has provided assistance in the eastern 33 states.

\section{Significance}

At low federal investment this program by providing support to many potential hydrothermal energy users, increases the probability. of proper resource development and utilization. User assistance enables users to make technical and economic evaluations prior to investing large sums of capital; thus development is stimulated by reaching a rapid, professlonally advised deciston. This program 
can lead to development of private support industry as more services are contracted out.

Past Results

Greater than $50 \%$ of the current Program Research and Development Announcements (PRDA's) and Program Opportunity Notices, (PON's) were stimulated through the technical assistance programs. In addition, many privately funded developments have occurred following technical assistance efforts. Examples are: PON's - Utah Roses, Madison County, Payosia Springs, Reno, Nevada, Four South Dakota projects and others; Private or Public Development, Bank-White Sulfur Springs, Montana, Hill Air Force Base, State Health Laboratory - Idaho, William Air Force Base - Arizona, and Many Private Dwellings. General Evaluation

The program has been quite effective in leading to power on Iine developments. Outreach elements have recently been unable, due to insufficient manpower (funding), to serve all of the referrals. A new program exists in Pacific Northwest, but little or no services are offered in Hawaii, California, or Texas. Eastern states for the most part are not ready for a Technical Assistance (TA) program. An aggressive outreach program must be instituted. Technical Assistance has only been done for direct applications, a similar program is needed for small utilities, municipalities and co-ops. 


\section{SPECIAL PROGRAMS}

\section{Description}

A need for special programs has been demonstrated which would provide technical assistance and support for particular groups who are not specifically involved in other DOE/RA program elements. These special programs have included: (1) Workshops run by DOE contractors in order to involve upper level management personnel from selected industrial sectors, and to obtain their commitment to investigate the feasibility of applying geothermal energy in energy-intensive processes in their industries; (2) DOE-sponsored projects to develop applications deadlines, procedures, and standards for trades to be involved in geothermal commercialization efforts, e.g., heating and plumbing contractors, (such as American Society of Heating, Refrigeration and Air Conditioning Engineers, ASHRAE), materials engineers, American Society of Testing and Materials, (ASTM), and building and system architects and engineers, American Institute of Architects, (AIA), and (3) Involvement with Native American organizations, such as United Indian Planners Association, (UIPA), who have been provided with technical assistance and resource assessment by DOE and/or its contractors. They are encouraged to investigate special institutional and legal problems that are specific to lands controlled by these groups. 


\section{Significance}

Commitments on the executive level have been obtained in the pulp and paper industry to provide technical data and assistance. This will be primarily an industry effort rather than a contractor effort to assess the feasibility of using geothermal energy in their industry. In specific trades that are essential to geothermal commercialization, efforts have been undertaken to develop guidelines and standards that would facilitate their efforts to apply geothermal energy technology in new situations. In the case of Native Americans whose lands are considered sovereign entities, especially intricate legal and institutional problems arise in DOE providing technical assistance. Not to neglect potential geothermal resources in these lands, these problems have been addressed and solutions are being developed.

Past Results

Involvement of industry executives has only been partially successful in one industry-pulp and paper. Efforts are ongoing to obtain commitments in the Food Industry as well as in other energyintensive industries. To date, the accent has been on utilizing high temperature resources. Little efforts has been expended on investigating uses for low and moderate temperature resources, which are more widely available and useful in a more generally available market. Trade-specific handbooks and standards have been initiated for only ASHRAE and ASTM to date. Aesthetically pleasing building 
designs that incorporate geothermal heating and/or cooling systems are important. However, only inftial contacts have been made with the American Institute of Architects regarding this. In some special cases, resource assessment and technical assistance have been provided by DOE contractors to National American groups. The implications of these activities have not been fully explored. 


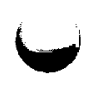




\section{PROJECT BROKERING}

\section{Description}

Project brokering consists of efforts to join together the necessary participants so that the initial commitment at a promising site can occur. Such assistance may include preliminary contacts by: Headquarters or field offices, contractors, members of GLGP to educate potential users, the financial community, architectural and engineering firms as well as actual coupling of resource owners, users, developers and investors on a specific project.

\section{Significance}

Public unawareness of the utility of geothermal energy, existing gaps in the infrastructure for direct applications, and the lack of experience with geothermal applications may inhibit or delay the first on-line application at a promising site.

\section{Past Results}

Examples of project brokering at the federal level include discussions between the Department of Energy (DOE) and the Department of Defense (DOD) which have resulted in potential geothermal space heating projects at Hill AFB and Williams AFB. Both of these facilities are located close to metropolitan areas and will stimulate the potential market for geothermal applications in the surrounding areas. The Idaho National Engineering Laboratory, in the field, and DOE Headquarters have assisted in securing funding sources for several local space heating projects, e.g., the state of 
Montana and White Silver Springs Water District, the state of Idaho for public health laboratory and the Warm Springs water district, and Environment Protection Act (EPA) funding for the Boise space heating project. Pre-negotiation assistance to potential applicants as a part of the outreach and technical assistance efforts, provided by the Oregon Institute of Technology (OIT), and the Jet Propulsion Laboratory (JPL, CA), have resulted in the preparation of successful PON applications at Klamath Falls. In addition, extensive project and àpplications development support has been provided to interested parties under the Geothermal Loan Guarantee Program (GLGP) to ensure that proposals are both technically and economically viable.

General Evaluation

Project brokering assistance has been instrmental in securing initial commitments to development of geothermal applications in many areas. However, present efforts, with the possible exception of the GLGP, are provided primarily on an adhoc basis, subject to staff interest and availability. A more systematic effort in the field is needed in order to induce and support effective commitment at specific sites. The ready avallability of a cadre of experts with practical experience in technical, economic and institutional aspects of geothermal development will be invaluable in the resolving questions of interested parties as they arise in a project, particularly with respect to community district heating systems. 
At the federal level, an important task is the Identification of alternative (non-DOE) sources of funding for geothermal development applications which do not qualify for financial assistance under existing programs. 


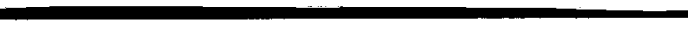


STATE AND LOCAL POLICY ACTIVITIES

\section{Description}

Through the National Conference of State Legislatures, (NCSL), DOE is supporting a state policy review program. The purpose is to identify those issues, statutes, and regulations which adversely affect the early commercialization of geothermal energy. Working with and through appropriate legislative committees, the NCSL may assist in the drafting of new legislation designed to accelerate the rate of geothermal implementation. Small programs by other DOE contractors support the NCSL work.

\section{Past Results}

In FY 1978, the NCSL policy review program was conducted in Oregon, Hawail, Utah, New Mexico, Virginia and Maryland. In FY 1979 the program will be extended to additional states. Recomendations for regulatory changes and new legislation have varied from state to state depending on particular needs. However, all have included such issues as resource characterization, state leasing policles, drilling regulations, tax incentives, and chartering of heating districts.

In support of the NCSL program, EG\&G Idaho is funding work in two specific areas which will add to the resource base of Information being considered by state legislative committees. An analysis is belng conducted on state tax structures and incentive programs. The purpose of these programs is to identify ways in which the 
state's taxing power may be used to stimulate, rather than deter, alternate energy development. An analysis has also been undertaken to examine state leasing and royalty arrangements, and the ways in which land policies may be modified to accelerate alternate energy development.

The OIT has contributed significantly to the evaluation of Oregon's progressive set of geothermal statutes. APL has worked with the State of Maryland in the development of that state's geothermal statutes, as well as having participated in NCSL policy workshops in Delaware and Virginia.

Another category of state policy related activity by DOE involves assistance in state implementation plans. This is provided for in the amended GLGP program (relating to community impact assistance), and the amended National Environmental Protection Act, (NEPA), regulations, both of which will affect geothermal development in the states. A study also supported by DOE jointly with the state of California, Geothermal Resource Impact Projection Studies, (GRIPS), resulted in the formation of a four-county Joint Powers Agency, (Napa, Sonoma, Mendocino, and Lake Counties). This provides the environmental base for local permitting decisions. Significance

Legislative reform at the federal level addresses only one dimension of intractable institutional barriers.

Significant institutional barriers also exist at the state 
and local levels. These barriers must be dealt with and resolved if geothermal commercialization is to be a reallty. Such programs as descrlbed above, particularly the NCSL work, must be strongly supported. The NCSL program has apparently been recelved very well. Its principal shortfall is that the program is being outpaced by events. In most states, project development (particularly PON field demonstrations) is underway and some difficult problems are being approached on an adhoc basis without the benefit of comprehensive review by the NCSL program.

Other attempts at joint federal/state actions obviously have to be approached with great sensitivity and respect for both real and imagined areas of state soverelgnty. One state of the Rocky Mountain region, for example, may decide before spring to spurn all federal assistance programs in energy matters as well as other spheres of potential cooperation with the federal government. 


\section{PUBLIC INFORMATION}

\section{Description}

Public information activities must be slanted toward both the general public, as In an awareness campaign, as well as toward specific targets of opportunity. The current DOE program includes:

(a) mailing of technical reports to a developed mailing list;

(b) development and dissemination of a couple of brochures; (c) development of a DOE funded movie presently being produced; (d) partial funding of GRC conferences; (e) development of exhibits; and (f) periodic news releases. Through its contractors, DOE has also placed exhibits in state fairs, local shows, energy expositions and trade shows, developed spot movies, developed and disseminated brochures at all levels; and made presentations pertaining to geothermal energy at many levels of public and private interest.

\section{Significance}

In areas where a reasonably continuous effort to develop interest in geothermal energy has occurred, the public is reasonably informed. Public interest develops both the specific and general support required to enlarge the geothermal community to become a viable, competitive industry. The use of both mass media and oneon-one interactions are required to insure a better understanding of the potential of this energy source.

\section{Past Results}

The results of the DOE/DGE contractors in the area of public 
information have been at best marginal. Even in the good resource areas of the United States, many of the local residents do not even recognize the term "Geothermal Energy". Specific areas like the: Imperial Valley, Callfornia; Bolse, Idaho; White Sulphur Spring, Montana; Delmarva, Susanville, California; and Klamath Falls, Oregon, have had sufficient activity and local involvement to stimulate the general public to a knowledgable and supportive level. General Evaluation

The public information element requires expansion and sustainment on a general level. The purposes of this effort are to increase the general level of public understanding in the basic technology, in the opportunities for utilization, and in the DOE programs available to assist the Initiation of geothermal projects. A campaign should be made at the national and local levels.

Specific informational materials aimed at one or more geothermal energy uses and/or one or more particular end use sectors, also need to be developed and made available. Both DOE and state offices should be used to disseminate the specific and the more general materials. Existing informational materials and information dissemination mechanisms should be used to the maximum extent possible to minimize costs. Maximum use of experienced staff is also essential.

General geothermal Image making can be accomplished through public service television spots, and national advertising through 
the Public Affairs office.

Headquarters should act as a clearinghouse for DOE materials, both Headquarters and field-generated so that materlals are shared and not duplicated. 

.

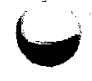


WORKSHOPS, CONFERENCES, SYMPOSIA

\section{Description}

The DOE and some contractors have, from time to time, sponsored several types of conferences to different audiences. The basic aim was to convey information gained from geothermal experience and programs. In addition to conveying information helpful to actual project development, contributions have been sought from industry sectors, utilities, state officials and the general public on policy issues and on DOE program development plans.

\section{Past Results}

The Geothermal Resources Council has sponsored two such conferences. The first, in January-February 1978, was a direct use symposium held in San Diego. In November 1978, the GRC held an even more productive commercialization conference aimed primarily at the electrical utility and financial sectors. In April of 1979, the GRC will also hold a direct use symposium on the commercialization of suspected geothermal resources in the East. Periodically, the Council holds toplcal workshops.

The NCSL regularly holds workshops on state policy issues which are aimed primarily at legislative members in the respective states currently included in the NCSL program.

EG\&G Idaho has held a number of commercialization meetings and workshops. In the sumer of 1978 , a state-utility-industry marketIng conference was held in Salt Lake. The meeting attracted 
executives and officials from the Rocky Mountain region to review DOE's marketing and commercialization plans for the region. In October 1978, EG\&G held a successful PON workshop which reviewed the specific demonstration projects and the PON program in general. In January 1979, EG\&G held a User's Workshop for state officials from the 10 state Rocky Mountain area, and later in the spring will offer three-day tutorial sessions for the professional engineering society of Colorado.

DOE sponsored a series of public workshops in California under the auspices of the Geothermal Resources Board on transmission corridors, state-utility relations, financial incentives, and direct use issues. The purpose was to provide a forum where state and local entities could identify problem areas and propose recommendations for resolution of interagency conflicts. DOE has also held public workshops seeking public critique and recommendations for federal legislation. The OIT also held a User's Workshop in February, 1978.

\section{Significance}

These categories of activities by the DOE and contractors can be extremely productive outreach vehicles. While generally effective, such conferences must be both targeted more effectively and with greater frequency. The format should depart from that which typifies most gatherings of professional societies and be devoted to commercialization objectives. Through its various chapters, for example, the Geothermal Resource Council (GRC) could be trying more effectively 
to effect a "grass roots users" level of geothermal interest: county and municipal planning groups, local and state financial institutions, urban and suburban development groups and agencies, and officials of state government. DOE contractors such as EG\&G, OIT, APL, and JPL should also hold frequent workshops as the type described earlier, emphasizing contact with professional engineering socleties, municipal and civic organizations, and other interest groups noted above. The emphasis of such contact should consist of the problems and opportunities of geothermal development: against conventional fuels; economic analysis of various applications, depending on the commercial or Industrial interest of the group; and provisions of the National Energy Act, (NEA), pending legislation, and the availabilIty of other government programs by which the development of geothermal energy may be assisted. 


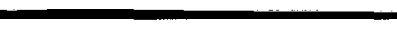




\section{FINANCIAL INCENTIVES}

\section{Description}

This element provides federal financial incentives to stimulate the development of resources and the use of hydrothermal fluids. Included in this program are the PON, PRDA and GLGP. The PRDA program is solicitation (with subsequent contract selection) to the public and private sector for proposals to perform both general and site specific engineering and economic analysis. The PON program is a solicitation to the public and private sectors for proposals to develop resources and construct utilization systems. PON projects are usually cost shared between DOE and the developer. The GLGP is a federal guarantee of an otherwise conventional bank loan for geothermal development in an amount up to $75 \%$ of the total project cost up to a hundred milition.

\section{Significance}

The significance of these financial incentives are: PRDA this type of evaluation provides the data required to determine the economic and engineering viability of specific applications at specific resource sites. Many of these evaluations would not be made without this financial assistance.

PON - The objectives of this program is to achieve power on 1ine. Fleld demonstration units are necessary for both illustrative and data collection purposes. This program also bullds the infrastructure currently mission. 
GLGP - provides for the up-front high risk capital during a time in energy source development when insufficient knowledge is avallable for financial institutions to finance within normal risk assumptions.

Past Results

PRDA - 3 solicitations - each solicitation has increased number of proposals - use of the data developed in this program is questionable. No summary document has been produced to interest the potential user section. Project management should be performed by technically competent managers to review and guide project status. There are no electrical PRDA type activities. PON - 2 solicitations - few industrial proposals - mainly space heating - no electric activities. $50 \mathrm{MW}$ plant at Vallez Caldera has been cost shared by DOE (this was not a PON solicitation). GLGP - underutilized program by private and public sectors 3 guarantees have been approved. Two electric and one direct app11cations - 12 received, 4 being processed. NEA tax incentives expected to improve this situation. It should be noted that the majority of the first year was expended developing operating procedures and marketing the program.

General Evaluation

Program Research \& Development Announcement (PRDA) - to stimulate interest and it should only be awarded to potential users. It is not awarded in sufficient quantity, and nothing is being done with the data output. PRDA's need to be cost shared and less should 
be spent on each study. There should be more studies and a wider range of studies.

Program Opportunity Notice (PON) - putting power on line, developing infrastructure, obtaining good press. Need more care In selection, requires better cost share - not good sollcitation technique for major potential users.

Geothermal Loan Guarantee Program (GLGP) - only financial assistance available for electric or major direct applications only granted 3 guarantees - procedure too cumbersome, needs streamlining. Need small business thrust. Loan rates are higher than prime rata. 


\title{
ATTACHMENT 8
}

\section{IDEAL PROGRAM MARKETING SUMMARIES}

\author{
TECHNICAL ASSISTANCE \\ SPECIAL PROJECTS \\ BROKERING \\ STATE POLICY REVIEW \\ PUBLIC INFORMATION \\ WORKSHOPS, SYMPOSIA AND CONFERENCES \\ FINANCIAL INCENTIVES
}


TECHNICAL ASSISTANCE

The committees consensus was that the existing technical

assistance program is quite functional and is serving a worthwhile

commercialization purpose. The current contractors have started

to become overloaded with requests. No real program structure,

other than the existing one was defined. Suggestions were as

follows:

- Use County Extension and Energy Extension Agents as Referral sources.

- Train state planning and outreach teams for simple cases and refer more technically difficult cases to laboratories.

- Have each state handle technical assistance through private companies on contract to the state. RA input will be provided when helpful.

- Coordinate all technical assistance activities through the Regional offices - possibly to use these offices for referrals to the states or regional offices to contract with contractors for technical assistance.

- RA - geothermal may not want a formal structure formed for technical assistance.

- If technical assistance does expand to cover all of the geothermally endowed states, control and management and management structure must be defined.

- DOE should examine the possibility of working with the political entities for economic development (comisstons such as the Four Corners Regional Commission and the Pacific Northwest Regional Commission) for placement of technical activities.

- Resource management skills and policy should be provided to state regulatory agencies where it is currently non-existent. 
- DOE should also look into providing services, through one of several means, that cannot be served by the existing infrastructure. Activities such as low cost well logging are currently not widely available. This element addresses the "Needs" list at least to a limited degree in the following areas: $2,5,6,8,9,10,11$, 15 , and 16 and provides output for 13 and 14 . 


\section{SPECIAL PROGRAMS}

Involving top level professional and industrial executives in cooperative DOE/Industry evaluations of possible geothermal energy applications is essential in order to obtain meaningful commitments of industry. However, to insure confidentiality of proprletary information, an unbiased third party is required. Universities seem to offer the best compromise, especially where they may have prior involvement with industry. The MIT experience has met with some success and it seems desirable to expand these efforts into new-industry classes. It is recommended that industry itself or other universities with prior industry involvement be sought for further programs along the same lines. Although prior experience with industry is desirable, it is not necessarily a requirement. In resource areas where a particular industry class is widespread, a local university could be more successful than a remotely located one. Alternatively, industry or industrial associations could be supported to conduct assessments of geothermal energy applications, thereby obtaining meaningful commitments by industry.

The MIT study to date has invited the largest companies in a specific industry, regardless of location to resources, to be included In their efforts. In addition, high quality resources have been considered for use. The merits of this approach way be in achleving location of new industrial plants near such resources. However, such an approach does little for the larger category of 
companies who could retrofit, but the local resources only have low to moderate temperature. Thus, two solutions may be offered: (1) include lower temperature resources in the industry-type studies to determine the lower temperature limits of technical and economic feasibility or (2) investigate a large industry having several companies colocated with a common resource. Both have merits in particular instances.

In interactions with trade and professional organizations, efforts need to be furthered with more emphasis on building and system design. As assessment of potential markets quickly leads to the conclusion that space heating is by far the largest, and also the most diffuse application for geothermal energy. Traditional convective radiators are not aesthetically pleasing in modern buildings. Thus, novel designs of both buildings and heating systems are called for. The more significant professional organizations involved hear are ASHRAE and AIA. Efforts have been undertaken with the former, but only initial contacts have been made with the latter. Therefore, it is suggested that efforts be made to involve the AIA, as well as similar organizations, in developing designs for geothermal applications.

Another target of opportunity centers about industrial process heat applications. In assessing these needs and potential matchings, fundamental process engineering studies must be conducted in order to identify potential ways of modifying existing processes to take 
better advantage of the geothermal energy resources. It is further recommended that the systems evaluated include hybrid systems, heat augmentation techniques, and innovative processes and systems involving energy cascading and byproduct recovery.

The above activities address the following items and the list needs: market analysis and assessment (item 1), technical assistance and information (item 5) to industrial manufacturing and professional groups through active interactions with these organizations and preparation of publications in their respective journals, industrial energy use intelligence and executive commitments (item 8), stimulation of direct use market (item 10), information dissemination to the general public (item 12), and identification of environmental baseline data requirements (item 14). 



\section{RECOMMENDED PROJECT BROKERING}

The committee agreed that brokering is a necessary and very important function. However, the brokering function has not been a clear, separate part of the DOE geothermal program (except perhaps GLGP). Although project brokering has occurred in the past, it has been on an adhoc basis and only to a limited extent. Where it has been performed, this function has been recelved as providing a useful and positive service. Thus, profect brokering has suffered in the sense that it has not been systematically bullt into DOE activities.

It was the committee's consensus that the Ideal DOE Geothermal Commercialization Plan include a spectfic brokering element. Basically, project brokering consists of assistance to potential developers/users in bringing together the participants necessary to secure a commitment on a geothermal prospect. A significant element of this would be assistance in the search of financing services. The public and private brokerlng functions are clearly different and separate efforts are required in performing each. Assistance needs to be carried out through design and start-up aspects.

One of the specific targets for project brokering should be performed by designating staff responsibility for stimulating interest in geothermal in public buildings, at local levels through the regions and states and in headquarters as needed. For example, one target group that has a tremendous potential for utilizing 
geothermal are military installations (i.e., Hill AFB). Other obvious examples include hospitals, schools, EDA supported public projects, HUD supported developments and other.

It was agreed that project brokering should be a headquarter's function with certain functions performed by Regional Representatives Offices, Laboratories, or DOE Contractors at the local and state levels. A vital part of this function is the necessity to have a Headquarter's staff person cognizant of the availability of all types of federal funds (DOE, DOD, VA, EDA, etc.) and the capability of spending a large part of his time in securlng funds for specific projects.

This element addresses "Needs" 9, 10, and 11. 
STATE POLICY ACTIVITIES

RECOMMENDED PROGRAM

The major effort being conducted in this program area is that of the NCSL. The description and successes were noted in an earlier assessment. At its present rate of progress, the time required for the NCSL staff to complete policy review activities in the Rocky Mountain Basin and Range Region will be 5-6 years. In the meantime, state policy problems as they pertain to geothermal will continue to be addressed on an adhoc basis. Therefore, to the extent that the NCSL program can be augmented, without diluting the quality of the work performed thus far, actions should be taken in that direction.

Efforts should also be undertaken by the regional teams to establish a working relationship with state offictals to address those policy issues which may require joint federal/state action. The resolution, for example, of multiple permitting requirements and duplicate bonding requirements; of required baseline environmental work in known geothermal resource areas could hasten commercialization. While the NCSL program appears capable of resolving important state regulatory and policy issues, joint federal/state coordination in the areas mentioned, as well as a host of others, is virtually absent.

This element addresses needs 3,4 and 14 . 
$1-78$

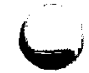


PUBLIC INFORMATION

This part of the program will supply basic facts about geothermal energy to the general public and will focus on some specific audiences. The public needs to know first that the resource is there, second that it can be used, third that it is environmentally safe, and finally that the country's cumulative geothermal resource can be a significant alternative energy-source.

To put a national program of this nature on line, copies of all publicity materials published or prepared by all sources should be sent to RA by the States, PON and PRDA contractors, and regional DOE offices and representatives. This means copies of all materlals prepared for public distribution, including past dissemination so far as that is possible.

To acquire additional information for preparation and dissemination, RA headquarters will receive and adapt data from the Progress Monitoring System to be put in place, and will contract for selective review of geothermal reports prepared for Resource Application, (RA), Energy Technology, (ET), other agencies and research groups.

A national contractor w111 prepare the information for national release and distribution under RA supervision. National distribution will include regional supervision. National distribution will include regional and state media, through arrangements with the public information structure to be established in the field (state, regional offices and representatives and regional information centers referred to below). 
Content and emphasis of materials to be released will be on accomplishments, knowledge gained will be applied, definite plans for applications, and serious efforts by market sectors to position themselves for possible applications will be established.

Two Regional Information Centers are needed to perform an intermediary role and to extend the program to national proportions. A third "Regional Information Center" for the Eastern United States will implicitly be a part of the information dissemination structure managed by RA at Headquarters. The Centers will concentrate on market entities and groups with which other parts of the program will be working such as financial communities, equipment manufacturers, national and local, civic and merchant groups, trade associations, journalists' and lawyers' groups as investment advisers, etc.

Certain public information tools have been prepared. They must be updated and become a part of consistent quality brochure film, exhib1t, press release, feature article, and other public information materials preparation systems. This coordination role will be performed by RA headquarters, with contractors' assistance. Needs addressed: $5,10,12$, and 16 . 
WORKSHOPS, CONFERENCES, SYMPOSIA

Workshops, conferences and symposia serve a valuable function as a point of contact for industry, other potential users, and government. Their formats can be tailored to serve special audiences, can support public information efforts, and to a limited extent can foster technical assistance.

Briefly, we recommend that workshops, symposia, and conferences be expanded in diversity of participants, in frequency, and in scope, with the goal always to create the most favorable climate for commerclalization.

At the federal level, more effectlve targeting should occur with a wider range of audiences. We recommend a more active role by the federal government. A charter for the federal role should include participation in all geothermal conferences from local to national levels, and sponsorship of two or three conferences per year. Regional representatives should be encouraged to help direct and, where feastble, sponsor local, state and regional workshops. DOE contractors should also sponsor conferences on both direct use and electrical applications.

If there is not now an Informal clearinghouse on conferences, DOE should institute one.

Federally sponsored workshops, conferences, symposia should set the tone for other such meetings. That is, these meetings ought to go beyond presentation of prepared papers to become opportunities 
for formal and informal brokering and other industry government interaction by including potential user and emphasizing commercialization.

Besides attending conferences specifically related to geothermal development and use, agency representatives might consider "piggybacking" other alternative energy conferences and workshops. For example, DOE could have been represented at the recent United States Department of Agriculture, (USDA), Congressional Conference on Renewable Resources. DOE staff should be specifically delegated and contractor designated to carry out this task. As marketing and policy needs dictate, the RA workshop budget allotment could be expanded. A more accurate gauge of user participation will help clarify this need.

Needs addressed: 2,5 and 15 . 


\section{FINANCIAL ASSISTANCE}

No one would suggest that a limited set of tax incentives will equally serve all the actors who may be important to geothermal development. Direct assistance and loan guarantees are the other major incentives which the DOE has available in its commerclalization efforts. The administration of these needs to be sufficiently flexIble to accommodate a wide range of user and developer needs and to support a variety of approaches to the DOE's pollcy goals. We will address the major programs in turn. PRDA's

The marketing working group agrees that PRDA's are conceptually and practically valuable, and wishes to recommend only one change in the program. We belleve the program could serve more customers and a greater variety of kinds of projects if the maximum PRDA funding level were reduced to $\$ 50-\$ 60 \mathrm{~K}$ from its present level. In many cases, significant basic (economic, technical, financial and legal) questions about a project could be answered by an effort funded at this reduced level. In other cases requiring larger efforts, R/A group may wish to require cost-shared PRDA's to leverage the federal funds. The marketing group cautions, however, that in considering the costsharing option, DOE should assure that such requirements would not exclude some desired participants in geothermal development from the PRDA program. We are especlally concerned that small municipalities not be prevented from taking this early step in geothermal planning. 
Finally, in this program, as in others, commercialization needs will be better served if the projects are managed and monitored to insure that information compiled is available and placed in useful formats, and that project results are coordinated with other efforts. In addition, timely authoritative review should be given prior to final reporting.

PON's

From DOE's point of view, funds distributed through the PON program create projects which demonstrate the technical and/or economic feasibility of some particular application of geothermal energy. To the recipient, the PON funds are a source of venture capital. The marketing working group belleves that the program should be structured to maximize the symbiotic relationship of these goals so that the best possible demonstration projects are produced. DOE must start with a clear idea of exactly what it wishes to demonstrate to whom and why. The federal interests should be the primary selection criteria and all projects should be negotiated to fulfill the DOE objectives. We believe, therefore, that the RA group should have a strong voice in determining the contracting mechanism under which the funds will be allocated and in selecting the particular projects to be funded. Only the RA group has a clear perception of how demonstration projects can serve the goals of commercialization.

Although cost-shared demonstration projects are a central part of the commerclalization effort, PON's should probably not be the 
only method for selecting contractors for cost-shared demonstrations. First, the short time frame for proposals excludes many bidders, that budget capital investment for at least a year ahead and cannot easily reallocate funds to a new project. A more flexible sollcitation allowing proposals to be submitted at any time during a year should allow a wider range of proposers including actual users to produce well thought out and well written proposals. There are, moreover, other problems with the PON procedure.

In many cases, the Industrial users make no binding commitments to development even if the resource proves adequate. The cost-share listed for the company proves, upon close examination, to be quite Insubstantial, consisting largely of land values (placed on land acquired without regard to its geothermal potential), and the use of facilities already in place. Not enough of the industrial proposals backed by or prepared by a consulting firm offers a significant cash outlay for development as part of the user's cost-sharing proposal.

In a larger sense, the PON's do not encourage continuous direct contact between government and potential users of geothermal which would help DOE discover the real needs of the whole range of possible developers. D1rect federal assistance is one tool which DOE can use to Induce energy users to utilize geothermal resources. However, the effectiveness of that tool in helping achieve public policy objectives will greatly depend upon the extent to which it creates 
opportunities for federal and non-federal cooperation. DOE must not merely place money in the geothermal community but provide proper stimulation for the development of geothermal energy. The PON by its nature is suited only to perform part of the required task. Other methods of allocating federal funds should be examined. We are not expert on the contractual mechanism avallable to accomplish this. One possibility is to use competitive cooperative agreements in which all parties understand at the outset that cost-sharing levels, project goals, technical assistance, and project management will be subject to negotiation. 


\section{LOAN GUARANTIES}

The loan guarantee program cannot be casually assessed, but a few comments seem in order. It should accomodate small as well as large projects. It should respond to innovative institutional structures such as the Intermediate Risk Assuming Company, (IRAC), for geothermal development. The GLGP should be tallored more specifically to the needs of small business and also to small municipalities; small municipalities in the RMB\&R face front-end financing problems similar to those experienced by small business, because of limtted tax bases, low flow of revenues, fully utilized bonding capacities, etc.

Access to the GLGP through local and state banks need to be greatly broadened throughout the western region. Administration of the GLGP will need to be decentralized from only the DOE San Francisco Operations office to in-state locations in order to be utilized effectively by the small businesses and smaller banks that both are accustomed to banking in more famillar territory.

More specific recommendations for the operation and management of the GLGP to service the basic requirements for direct thermal applications are listed below:

- Increase the federal government guaranty level from $75 \%$ to $90 \%$ for municipalities and for businesses or direct thermal applications that qualify as small by size of business, size of loan guaranty, size of geothermal project, or some other appropriate criteria. (a) 
- Provide for decentralized administration of GLGP through local or state offices of the Economic Development Administration, Farmers Home Administration, and/or Rural Electric Associations - i.e., those established agencies who have knowledge of or experience with specialized small business financing. (a)

- Reduce the interest rates to the borrower through the federal government subsidizing the differential between the current bank rate and a preset rate such as is being done in the small hydroelectric loan program. (a).

- Simplify the application requirements and streamline the approval procedures in order to reduce time and costs to the small business applicant.

It appears that a sliding approval/authorization procedure is required. A small loan should not require the same authorization chain, that published in DOE 4650.1 , as a maximum loan. The responsible field office should have authorization up to a given level, the RA/GRMO for the next level and only the complete DOE 4650.1 authorization chain for large projects. This approach should simplify the process for obtaining a loan guaranty.

- Provide for flexibility for timely adjustments in the payable schedule in order to accommodate changes in cash flow, profit, economic environment, production factors, etc.

We can say again that the GLGP procedures need to be streamlined. How much of this streamlining has been accomplished through the new regulation is not clear. If it does not begin to fulfill its early promise soon as a major stimulant to developers and users, it should be reorganized completely or be replaced by a more responsive program.

(a) Requires additional leglislation. 
AGGRESSIVE ASSISTANCE

Non-recource loans and direct loan programs fall into a category of very aggressive government Incentive programs which are probably not possible unless the national energy policy is revised. to emphasize development of geothermal resources. Our only suggestion here is that the RA planning group prepare to suggest and defend specific aggressive incentives as opportunities become available. 


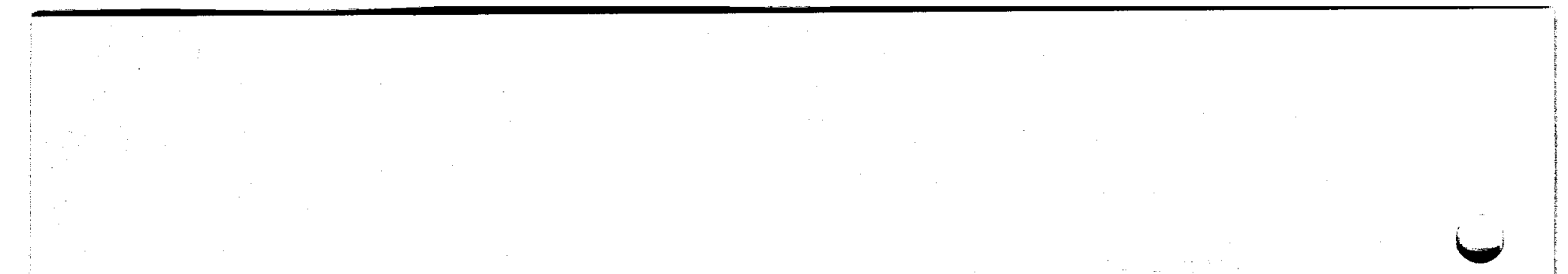


ATTACHMENT 9

RECOMMENDED METHODOLOGY fOr MARKET DEFINITION 
RECOMMENDED METHODOLOGY FOR

MARKET DEFINITION (FIGURES $1-1$ thru 1-4)

STEP

1. Define geotherma1 resource

- Quality (temperature etc.)

- Location and aerial extent

2. Screen potential users by required temperatures and applicability

of steam/hot water energy (not for transportation or singeing chickens)

3. Overlay resource locations and potential user locations to establish colocation feasibility (MAP)

4A. Industry analysis:

1st Cut: National level computational approach using standard industrial codes (SIC), to identify major energy consumption

Intertechnology report (low temperature, technology approach).

Overlay on similar approach of county analysis of energy consumption

Results in priority ranking of industries and counties, (which defines thrusts for marketing).

FOLLOW-UP: Identify target companies and counties for site visits and surveys to determine consumption processes, usage rates and plans. (This activity starts the marketing outreach program). Very costly and effective effort.

4B. Residential/Commercial

- Space conditioning - BTU/person/year/degree day

- Water heating - BTU/person/year 
Analyze on a "local" basis, dependent on population density, versus resource location

- Suggest analysis at metropolitan tract and minor civil division (MCD) level, if resource data permits; county data may be coarse.

- Note: Brookhaven is preparing to do a national (state by state) analysis, if permitted to continue. A preparatory conference is needed to decide/agree on input and assumptions to use.

- Project independence report data is on BTU/sq. ft. basisrequires similar information on industry sq.ft. Brookhaven has converted the same data base to BTU/person basis

- Caution: Recuperators from high temperature energy systems are increasing in use, with corresponding decrease in space and water heating systems.

4C. Military Uses Federal Facilities

Actual energy consumption numbers from military bases are available on DOD computers and printout (quarterly reports).

- Recommended DOD output to establish colocation opportunities. DOD or DOE can do by computer.

A similar analysis should be expanded to federal facilities as a whole.

4D. Agriculture

The computational approach matching energy consumption location with resource location is justified, using USDA, BuCENSUS and state agriculture department data.

Analysis of specific crops is not worth doing unless major production and high energy consumption warrent. In such cases, the computational approach is not very good. Potential specific crops include: soybeans, poultry, dairying, alfalfa drying, tobacco, peanuts. Most crop drying is done at elevated temperatures; geothermal conversion, if feaslble, will require new equipment and techniques. In cases that are justified, direct contact with, and survey of specific companies should be conducted. Typically, agricultural processes are geographically diffuse and limited to short campaign times, giving poor utilization factors (e.g. 10-30\%) Cooperative hook-ups to district heating systems might be feasible. 
General Comment:

Graphical overlays of data on maps are effective.

\section{Definition: Product}

Concept of using geothermal energy for all types of applications with replacement potential. DOE's role is that of a marriage broker. 
DIRECT HEAT USE

MARKET DEFINITION - RECOMMENDED METHODOLOGY

PRODUCT: CONCEPT OF GEOTHERHAL ENERGY USE FOR ALL REPLACEMENT APPLICATIONS.

- DEFINe GEOTHERMAL RESOURCE $<$ QUALITY (temp., etc.)

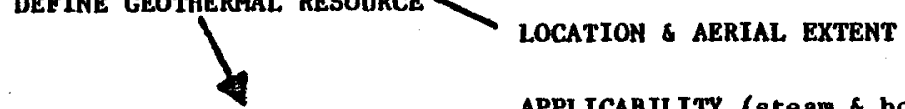

- SCREEN POTENTIAL uSERS APPLICABILITY (steam \& hot water)

In

TEMPERATURE REQUIREMENTS

ESTABLISH COLOCATION FEASIBILITY (map overlay)

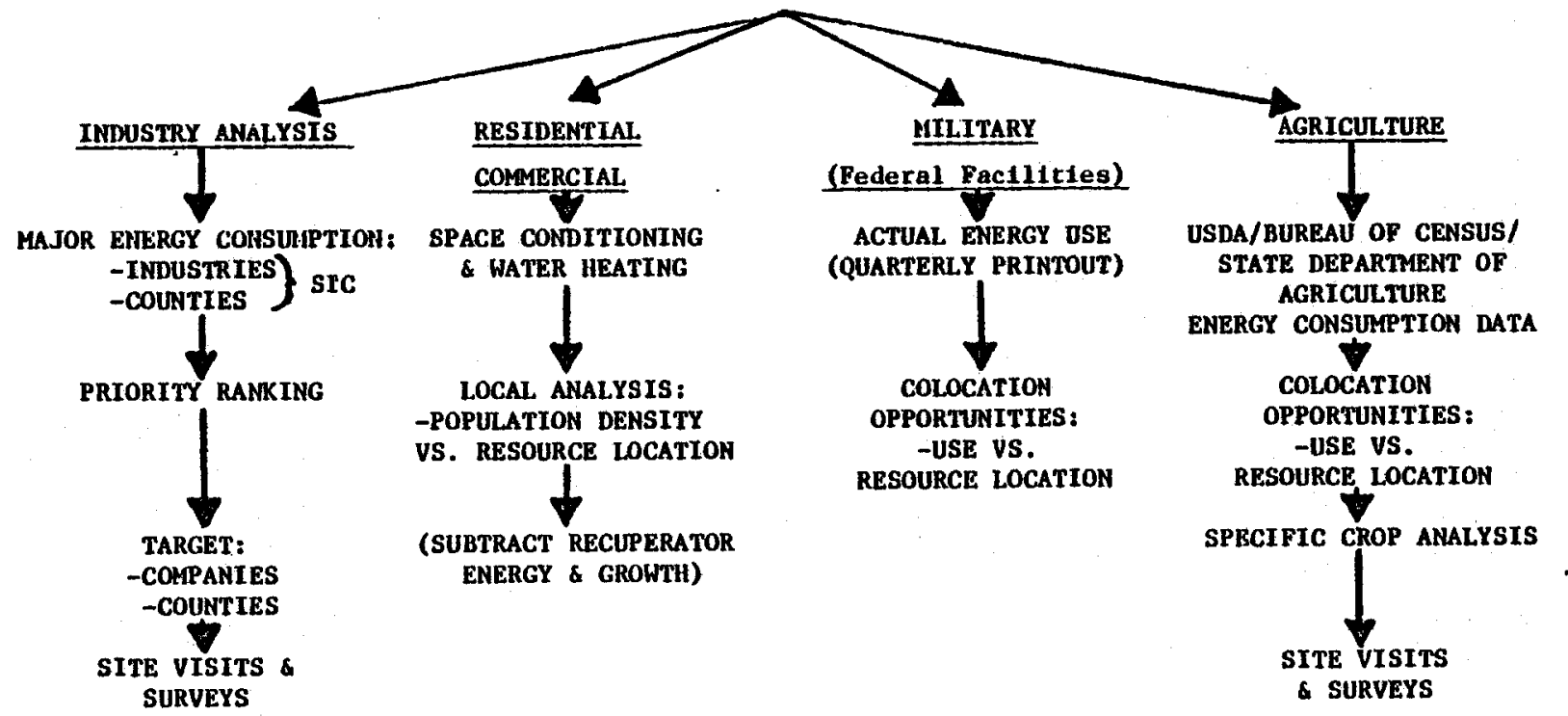

FIGURE 1-1 


\section{- PReliminary estimates:}

- Resource Temperature

- Resource Extent

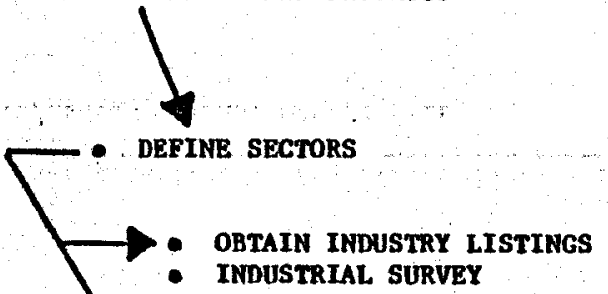

- INDUSTRIAL SURVEY

CALCULATR RESIDEMTIAL/COMaRCIAL MARKETS

- Beat Modela

- Bu Census Data

$\longrightarrow$ CROP DRYING RSTIMATES

- USDa \& bUREAU CEnSUS DATa

- POULTRY production space heating estimates

- Survey Poultry Producer Requirements

FIGURE 1-2 
1. BASELINE MARKET

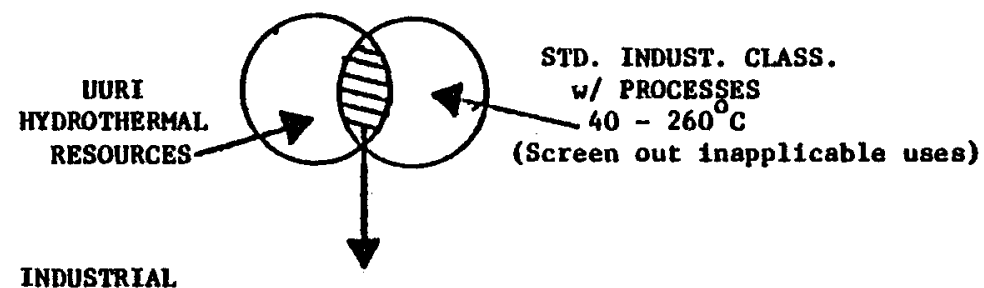

Assumptions

50X Cycle Effictency ( 2 X Consumption 1975 Data (1972-1975)

Employees X M BTU/Yr/Employee X SIC Category Factor (Product Correction)

$+$

RESIDENTIAL/COMARCIAI

Population X Energy Use Factor (Climate - Adjustment for CookIng, Lighting \& Appliances)

$\sum$ COUNTY-LEVEL DATA - STATE/REOION CURRENT MARKET SIZE

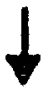

2. MARKET GROHTH POTENTIAL

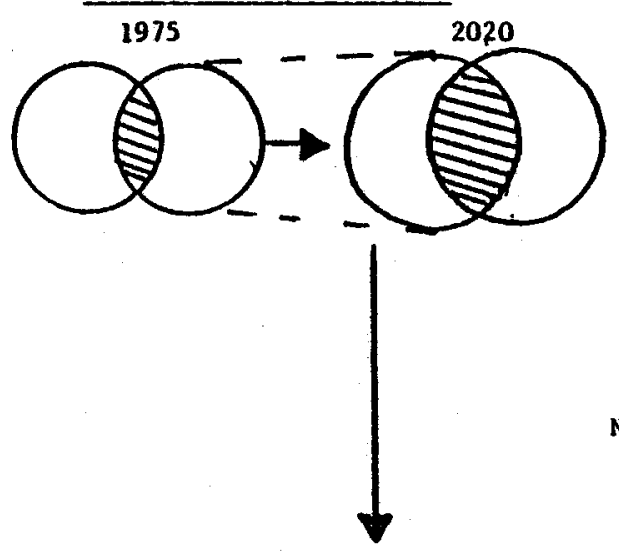

(3. MARKET CAPTURE POTENTIAL)

\section{Existing Indugtry:}

Induatrial: SIC Category Growth Rates (Ford Foundation or Local Projected to 2020 (Compounded)

$+37 / \mathrm{Yr} /$ Capita (Compounded) Increased Consumption

+ New Suppliers 8 Servlces:

$+5 \pi / \mathrm{Yr} /, 1985-\mathrm{on}$

+ Relocating or Converting Industries:

$68 \%$ of Industrial Growth ( $=$ Steam/Process Heat $z$ )

Resident1al: 4z/Yr. (Project Independence Report)

Commercial: + 3z/Yr/Capita (Compounded) Increased Consumption New Discoveries: 2000-on

Range: $0 Z$ (NV) to 15-20Z (AZ, ND, SD, NM)

FIGURE $1-3$ 


\author{
FIGURE 1-4 \\ METHODOLOGY - ELECTRIC POWER
}

- RESOURCE LIMITED, NOT USER LIMITED

- MARKET AVAILABLE THROUGH EXISTING GRID

- MARKET FACTOR DERIVED FROM TEIPERATURE/ECONOMICS DETERMINATION

- TIMING OF MARKET ASSUMES LOWERING OF ECONOMIC TEMPERATURE LIMIT OVER TIME 


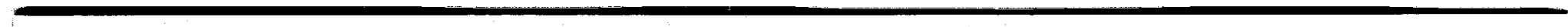

ATTACHMENT 10

INTERNATIONAL MARKETING

EVALUATION

$1-101$ 


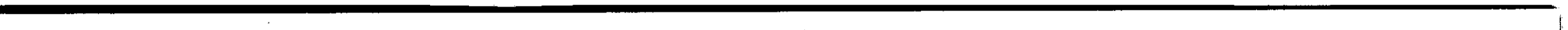


INTERNATIONAL MARKETING

A significant rationale for marketing geothermal technology overseas is that export markets provide an opportunity for expansion of U.S. manufacturing capacity in preparation for the emerging domestic geothermal market. A relevant question is whether the percelved foreign market justifies the entry costs.

It should be noted that every industrialized country has the technological capability for competing in the LDC market for power plant equipment and construction. The U.S. presently has an advantage in terms of drilling technology due to previous experience with 011. and gas and geothermal exploration and established foreign sales networks.

With few exceptions, the present market for geothermal technology is among LDC's because they are most sensttive to Increased petroleum prices and are actively looking to the development of Indigenous energy resources. As most LDC's lack either experfence with geothermal development or the expertise to closely manage a power plant project from exploration through construction; they have relied primarily on turnkey projects and the services of international A/E consulting firms.

Geothermal development projects among LDC's have been financed historically through the exploration phase by grants from the United Nations Development Program (UNDP); financing for the later phases of development has been provided by international development financing 
institutions such as the International Bank for Reconstruction and Development (IBRD), and the Interamerican Development Bank, sometimes in combination with some form of vendor financing supplied by major equipment manufacturers. 1

There are essentially three kinds of markets in geothermal turnkey projects:

$\%$ of total project cost

I. Exploration/feasibility study

II. Field development/production

III. Power plant construction

$$
3 \%-10 \%
$$$$
35 \%-42 \%
$$

$55 \%$

In the exploration and feasibility study phase, geothermal projects are generally subject to international bidding, and U.S. exploration and $A / E$ companies are in a fairly competitive position relative to other international companies. In the field development and production phase, established firms with local contacts have a significant economic advantage over firms which must bring in their operating equipment and personnel. For example, Foramines (France) has a signal advantage over other drilling companies in Central America until such time as the market justifies establishment of a local operations base by another firm. In the power plant construction phase, U.S. A/E firms and equipment manufacturers are at a disadvantage because they cannot provide equipment financing which is

Most international financing institutions review the economic feasibility of the project, the credit worthiness of the country, and the utility of specific projects prior to granting loans. In many instances, they provide the technical expertise which firms up the energy planning processes of an applicant country.

$$
1-104
$$


competitive with that of Japan, Italy, New Zealand or France. The major advantage that companles from these countrles have over U.S. companies is close government-business cooperation in the development of a business opportunity and ready availability of vendor financing packages. ${ }^{2}$ Financing options available to these companies which are not avallable to U.S. companies include:

- Government to government arranged exchanges of oll dollars for technology

- Loan and aid agreements which are tied to the purchase of technology from the grantor country

- Long-term, low-interest loans which are avallable on a short turn around time for particular projects.

With respect to future export of U.S. designed and manufactured small scale geothermal power plants, this preliminary examination of financing and marketing patterns in turnkey projects suggests that while a potential market may exist among $L D C^{\prime} s$, there are significant market barriers to entry into these markets in the form of competitive vendor financing. The same considerations are applicable even though sales of goods and services are on a discrete rather than turnkey basis unless the product is unique, e.g., the helIcal screw expander. ${ }^{3}$

\footnotetext{
Another competitive advantage enfoyed by Japanese turbine/generator firms is the significantly lower price of their products compared with those from the U.S.

${ }^{3}$ It was observed that there may also be cost-rellability trade-offs in the purchase of equipment by LDC's. That the primary considerations in the purchase of equipment may be rellability of operation and ease of maintenance rather than price. This also suggests that LDC's may prefer equipment with a track record and discount the potential advantage of high/new technology equipment.
} 
A conclusion which may be drawn concerning program development for marketing geothermal technology overseas is that: the LDC market for small power plant/well head generators is not a primary market in terms of balance of trade considerations at present; and marketing activities for small power plants may need to be supported in the near term by some other rationale, such as those listed below.

A number of non-commercialization related policies expressed by legislation and initiatives that will influence the nature and extent of DOE/RA's involvement with LDC's are:

- Nuclear Non-Proliferation Act (1977) encouraging the deve1opment of alternative sources of energy

- International Development and Food Assistance Act of 1977 U.S. to provide technological assistance for development of indigenous energy resources

- International Energy Development Program (1977) - U.S. to cooperate with other industrialized countries in meeting energy needs of LDC's

- Foundation for International Technological Cooperation (3/78)

- using U.S. scientific and technological knowledge to accelerate development in third world nations.

These policies call for DOE to cooperate with the Department of State and the Agency for International Development in the provision of technical assistance to LDC's for the development of indigenous energy resources, primarily in support of the following objectives:

- nuclear non-proliferation,

- economic development assistance,

- diplomatic, and

- energy conservation 
The major criteria for international activities in the energy area is the existence of reciprocity between the U.S. and participating countries. The balance of such exchanges is evaluated in terms of meeting each country's expectations rather than a requirement that the exchange be equal. The priortty of applicable considerations (economic, polftical, technical assistance) may vary with a specific cooperative activity and will need to be reviewed on a case by case basis.

Recommendation: Pending closer definttion of market opportunities among LDC's for recently developed U.S. geothermal technologies, DOE/RA's participation in intemational activities can be used as opportunities to examine alternate patterns of geothermal development. This can support the broader commercialization objective of domestic infrastructure development and early acceptance of geothermal energy worldwide by Improving the development of solutions and encouraging the serlous evaluation of geothermal applications among LDC's. Useful areas of analysis include:

- Second generation issues assoctated w1th geothermal deve1opment in the United States, e.g., institutional environmental barriers in comparable socleties, interface of geothermal applications with conventional utility systems, and patterns of brokering intemational geothermal projects.

- The potential for small-scale, decentralized application of geothermal technology.

- The potentlal for reverse technology transfer from abroad which may have a significant cost reduction effect in the commerciallzation of speciflc applications in the U.S. 
Specific actions needed to define an international marketing strategy for DOE/RA are:

1. Definition of the relationship of existing international technical and economic assistance activities to commercialIzation of geothermal technology objectives.

2. Review of existing agreements to identify opportunities for improving information gathering for international marketing activities, e.g., the visiting scientist program, trip reports.

3. Integration of existing sources of information on potential geothermal markets. This may be in the form of an international market study or as a part of energy assessments conducted by the International Energy Development Program, (IEDP). The effort should define levels of risks and uncertainty; location and size; social, economic and political forces for change in those markets over the short term future. In particular, the nature of the international market for direct use applications in the context of distributed energy systems has not yet been explored.

4. A cost-benefit analysis of the impact of export expansion activities on the domestic commercialization program. The effective use of export markets to enhance commercialization of geothermal technology is a function of the government's capacity to sequence such activities to problematic techno- 
logy and infrastructure development efforts in the U.S., taking advantage of the expanding interest in geothermal energy in both developed and developing countries.

Table 1-V describes International Geothermal Financing since 1972 in Developing Countries. 
TABLE $\mathbf{V}$

INTERNATIOHAL GBOTHERMAL, FINANCING SINCE 1972* IN DEVELOPING COUNTRIES

\begin{tabular}{|c|c|c|c|c|c|c|c|c|c|}
\hline AGENCY & COUNTRY & 1972 & 1973 & 1974 & 1975 & 1976 & 1977 & 1978 & 1979 \\
\hline $\begin{array}{l}\text { United Nations } \\
\text { Development } \\
\text { Program (UNDP) }\end{array}$ & ChtLe & & & & . & $1.8 \mathrm{BH}$ & $\begin{array}{l}3.5 k \\
\text { (Feasi- } \\
\text { bllity } \\
\text { Study) }\end{array}$ & & \\
\hline & IHDONESIA & & & & & & $\begin{array}{l}7.7 k \\
\text { (Train- } \\
\text { Ing } \\
\text { Project) }\end{array}$ & & \\
\hline & JORDAN & & & & & & $\begin{array}{l}114.92 \mathrm{k} \\
\text { (Explor- } \\
\text { ation) }\end{array}$ & & \\
\hline & ROMANIA & & & & & & $\begin{array}{l}4 k \\
\text { (Explor- } \\
\text { ation) }\end{array}$ & & \\
\hline & MEXICO & $\begin{array}{l}1.25 \mathrm{M} \\
\text { (Power } \\
\text { Plant } \\
\text { Construc- } \\
\text { tion) }\end{array}$ & & & & & . & & \\
\hline & $\begin{array}{l}\text { KENYA } \\
\text { COSTA RICA }\end{array}$ & & & & $\begin{array}{l}500 \mathrm{k} \\
\text { (Grant } \\
\text { Explora }\end{array}$ & & $\begin{array}{l}94 \\
\text { (Drilling- } \\
\text { Olkaria) } \\
15 \mathrm{Me}\end{array}$ & & . \\
\hline
\end{tabular}

*Figures given represent the amount of contribution or loan to project and not the total cost of the project. 
ECONOMICS

SECTION 2

2-1 


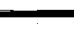




\section{REPORT OF TEE ECONOMICS COMMITTEE}

for the workshop on

"COMMERCIALIZATION OF HYDROTHERMAL RESOURCES"

held at MITRE Corp. Metrek Division

McLean, VA Jan. $29-$ Feb 9, 1979

Committee Members: C.H. Bloomster, Chairman, Pacific Northwest Laboratory (PNL)

Abdul E1-Sawy, MITRE

Tom Lawford, Idaho National Engineering Laboratory (INEL)

B11l Barron, Applied Physics Laboratory (APL)

Richard Weissbroad, Applied Physics Laboratory (APL) SUMMARY AF THE FINDINGS OF THE COMMITTEE

Economics research and analysis supports two main functions: (1) program planning and budgeting; and (2) marketing. Most economics research provides information which serves both functions. Generally, aggregated and generic information 1s most useful for program planning purposes, and disaggregated and site-specific information is most useful for marketing.

Previous economics work was directed primarily at program planning and budgeting. To evaluate production costs, good economic models were developed. The areas which are well understood are the effect on hydrothermal production costs of: resource characteristics; reservolr and power plant designs and operating conditions, and financial and tax policies.

The effects of non-price factors are not well understood, particularly the effects of uncertainties in resource characteristics and sys- 
tem performance on market penetration. Therefore, the main needs that should presently be addressed are: (1) the development of more credible models for predicting market penetration, in both the electric and in the direct application areas, and (2) more thorough assessments of the potential economic impacts of uncertainties in resource characteristics, reservoir performance, and power plant performance. These uncertainties lead to questions of financial risk, and reservoir and power plant reliability which must be assessed.

The basis is well developed for selecting the most promising hydrothermal resources for commerclal electricity generation. However, the basis is not well developed for selecting the most promising resource for direct applications. The main needs to support marketing in the direct applications area are: (1) more detailed site-specific studies which match the needs of potential users to the characteristics of the resources, (2) more thorough understanding of the most efficient marketing systems, and (3) better resolution of questions relating to uncertainty, risk, and reliability for specific reservoirs and end uses. Many non-electric applications will require a large scale market to be economic. Therefore, for efficient marketing and distribution a well organized market structure must be developed.

Marketing for electrical applications also requires better resolution of questions relating to uncertainty, risk, and reliability. Uncertainties and risk, particularly as they relate to the reservoir, have been obstacles in obtaining commitments from utilities for geo- 
thermal development. In addition, research into pricing alternatives is needed. The current practice of indexing geothermal energy supply prices to prices of other energy sources may be a significant deterrent to comercialization. Alternative pricing mechanisms such as those related to long term production costs may be more favorable to both buyer and seller.

Currently most hydrothermal resources are uneconomic to produce. Continued economic analyses are needed to identify the most cost effective R\&D programs and to evaluate the economic impact of alternative tax and regulatory policies. In addition, there is a continuing need to update the current economic data base in response to changing technology and market conditions for both hydrothermal and competing energy sources.

Economic research supports comercialization in two ways. First, in the overview perspective by demonstrating that a large, economically significant supply and demand will exist. Producers, consumers, intermediaries, and servicing organizations are encouraged to devote greater effort to geothermal energy exploitation, which may achieve economies of scale and mass production. Greater technical innovation, and more efficlent, market delivery and regulatory systems are also required. These achfevements can lead to large scale market penetration. Second, on a specific project basis, commercial ventures are supported by demon- . strating that sufficient economic and financial justification exists. The comittee identified and ranked 23 research needs (Table $2-I$ ). One additional research topic was added later. 
$2 \cdot 6$ 
TABLE 2-I

Ranking of Identified Research Needs In Economics Eigh Priority

1. Risk and rellability analyses

2. Cost benefit analyses related to $R \& D$ programs

3. Market penetration models

4. Market penetration analyses

5. Systematic studies of non-price market factors

Intermediate Priority

6. Site-specific Industry studies

7. Systematic comparisons or standardization of economic analyses

8. Studies of export market potential for geothermal industry

9. Updating and refinement of production cost models

10. Economic analyses of environmental control costs and systems

11. Analyses of barriers to market entry and expansion

12. Development of better risk and rellability models

13. Updating supply curves and sensitivity analyses for major uncertainties

\section{Low Priority}

14. Regional economics analyses

15. Development of marketing games

16. Infrastructure analyses

17. Cost benefit analyses from the social welfare standpoint

18. Venture analyses

19. Development of better demand models

20. Generic demand analyses 
21. Economic studies of technology transfer to less developed countries.

22. Development of new production cost models

23. Additional net energy analysis

\section{Late Addition (Unranked)}

24. Cost-benefit analysis of government incentive programs. 


\section{OBJECTIVES}

The three objectives of the economic committee were to:

1. Describe the role of economics in the commercialization process;

2. Establish the current status of economics knowledge as it pertains to the commercialization of hydrothermal resources;

3. Identify gaps in the knowledge and recommend actions needed to support commercialization.

\section{THE ROLE OF ECONOMICS}

In the area of planning, economic analyses are seen as tools to evaluate long and short term goals; to select the most promising resources; to evaluate the timing and magnitude of market penetration; to evaluate policy alternatives; to evaluate the effectiveness of R\&D programs; to evaluate the relative competitiveness between geothermal energy and competing energy technologies; and to evaluate the potential for geothermal energy in speclalized industries. The aggregate of all of these studies will be usable for planning purposes.

Economics will be used to support marketing in two basic areas: generic studies performed as a function of generalized resource parameters and financial characteristics; and site-specific studies performed for a specific resource and with financial characteristics appropriate for a specific developer and/or utility. The generic studies will be used to estimate the size of potential market and stimulate general interest in geothermal power. The site-specific studies will be used to supply additional stimulus and help establish 
economic viability to potential developers and utilities.

Through an analysis of the factors affecting supply and demand, economics seeks to: (1) predict the degree of market penetration, and (2) identify actions and events which would increase market penetration. On the supply side, economics seeks to describe and differentiate hydrothermal resources as to their suitability for electrical or direct applications. Criterfa for suitability are costs of production, size, availability, and reliability of the resources, environmental and social costs and benefits, and constraints or limitations on the efficient uses of the resources. On the demand side, economics seeks to describe and differentlate the potential markets for hydrothermal resources so that the most efficient uses of hydrothermal energy can be identifled. Identification criteria include size, location, and the physical characteristics, (e.g., minimum temperature requirements) of the potential demands, degree of substitutability of hydrothermal energy, and the structure and functioning of the market.

\section{CURRENT STATUS AND IDENTIFIED RESEARCH NEEDS}

ANALYTICAL METHODOLOGY AND MODELS

\section{Production Costs}

For both electrical and direct applications, there are adequate models and acceptable methodologies for production cost analyses. Further development is not currently necessary, but it is important that the models continue to be improved and the data base be kept 
up to date in order to respond to rapid changes in technology and resource information.

Al though adequate methodologies exist, substantial differences exist in the production cost estimates. These differences stem mainly from the assumptions used and the methods of treating inflation. There is a need for standardization in order to provide comparability or reconcillation of results. Needs will develop for more detalled site-specific production cost analyses to support the marketing work.

Venture, Risk and Reliability

The methodology and models for these types of analyses appear to be adequate but have not been demonstrated with completeness.

So that acceptable rellability analyses can be undertaken, the range and distribution of uncertainties in resource characteristics, reservoir performance, power plant performance and other factors need to be defined in much more detall.

Reservoir Economics

Adequate models which couple economics with reservoir engineering and resource utIlization do not exist. Further development and veriflcation of reservolr engineering models is required before $1 t$ becomes useful to couple them with economic and utilization factors. Models need to be developed which address both the exploitation and assessment activities and the reservoir design and management activities. 
$\underline{\text { Demand }}$

Adequate methodologies and models exist for deriving demands for both electrical and direct applications.

Analyses of Competing Resources and Potential Market Penetration

Adequate methodologies and production cost models are available to analyze the potential effects of the competition on geothermal resources. Models for estimating the potential market penetration for all new energy technologies need much more refinement to increase their creditability.

\section{Market Games}

The interests and roles of the different parties involved in geothermal development can be adequately captured by properly designed management games. These games could simulate the interaction between the key figures of the Federal, State and local governments, field developers, utilities and other parties that have an active role in geothermal development. The function of a game is twofold: educational and promotional. It introduces the participant to all the key factors governing the geothermal development processes and allows him to play out his options and receive a timely feedback on the outcome of his decisions. To date, no geothermal development games have been designed. The need for such games to support and stimulate marketing activities should be evaluated by the marketing team. 


\section{ISSUES RELATED TO SUPPLY \& DEMAND}

\section{Electrical Application}

The geothermal supply curve has been relatively well-defined for program planning purposes. The sensitivity of production cost to uncertainties in resource characteristics, financial factors, and major factor costs and inputs is known. However, uncertainties exist as to the impact of certain site-specific factors on production cost, such as the avallabllity of cooling water, drill rigs, and environmental factors. The supply curve should continue to be refined to take these factors into consideration. The supply curve should also continue to be updated to take into account changes in technology and new data on resource characteristics. Elements of uncertainty and risk should be Incorporated Into the supply curve. The need for and the impact of technology improvements whlch lower production costs for hydrothermal resources should continue to be evaluated.

\section{Non-Electrical Applications}

Preliminary supply curves have been derived for the identifled hydrothermal resources, but these should be developed in more detall and correlated with actual and potential demands near the resources. Supply curves for low temperature resources $\left(<90^{\circ} \mathrm{C}\right)$ have not been developed because of lack of resource assessment data. Continued work on supply curves is required to achleve a higher degree of usefulness for both program planning purposes and for marketing activities. Methods of ranking the most attractive sites for commercialization 
are not well developed, because the size and location of the supply and demand are so interdependent.

Determination of Demand

Demand estimates either exist or can be derived readily for space heating applications. Demand estimates for process heat are fairly well defined for the major industries, but determining process heating demands for specific sites is laborious. Estimates of the process heating demands surrounding the most attractive resource sites should be determined in order to promote commercialization.

\section{Industry Studies}

Numerous studies of industrial applications of geothermal energy have been conducted. Although many of these studies have addressed an industry in a generic sense, others, notably by MTP and APL, have evaluated individual plants, and conducted interviews with plant managers concerning the nature of their energy requirements (e.g., temperature level, quantity, and load requirements).

Further research in this area, particularly for low temperature applications, may be valuable, but the emphasis of future research should be directed to industries located near a specific promising geothermal site. The implication for load management and reservoir management of combined process and space heating utilization of a reservoir should be more fully explored. Although the direct benefits of a new industry can generally be quite readily determined, the 
multiplier effects on local economies from the types of industries most likely to relocate to geothermal sites appear to be much less well understood.

\section{COST BENEFIT ANALYSIS}

Cost benefit analysis provides a framework through which considerations of public concern can be included along with market considerations in an economic evaluation. The benefits related to energy resource diversification and the geographical dispersion of these resources are not reflected In market decisions, but are important concerns to public policy making. Energy diversification, for example, has significant national security implications, and may have environmental benefits as well, which do not enter into the decisions of businesses. Cost benefit analyses are also useful in making explicit the costs and benefits and in 1dentifying the tradeoffs between costs and benefits. To the degree that such benefits are important to the nation, there may be reason to provide governmental support to the development of hydrothermal resources which are not currently competitive. Once the decision to support a new energy technology has been made through the political process, cost benefit analysis is also valuable in suggesting the most appropriate forms of such support.

The comittee was aware of no comprehensive cost benefit analysis of geothermal energy development. In the case of geothermal energy, the high potential losses to a private developer during the early 
years of a project when load factors are low, and the risk associated with projects in areas of unproven resource capacity, present obstacles which may be reduced through governmental support. Cost benefit analyses of short term subsidies and other forms of support for new utilization projects should be undertaken to determine if such types of support are justified. In the case of low quality hydrothermal resources which are marginally competitive at present, cost benefit analyses should be undertaken to identify both the degree of subsidization required and the potential long term benefits from development of these resources.

\section{REGIONAL ECONOMIC ANALYSES}

Available information on economic analyses suggests that relatively little research has been conducted on the regional impacts of geothermal energy development. Analyses with a regional perspective should be encouraged to assess: (1) local multiplier effects of geothermal energy development, and (2) potential development constraints imposed by an inadequate infrastructure, particularly if several geothermal projects were begun during the same period.

While the relocation of industry to a geothermal site cannot be considered a national benefit in terms of employment or output, such considerations are of major significance in an assessment of the regional impact of geothermal energy development. The addition of the direct employment and tax benefits, as well as multiplier effects on secondary industries, to the benefits of lower energy costs or more 
secure energy supplies may be a major inducement to a region to stimulate the exploitation of its geothermal resources.

The analyses of the potential growth of the geothermal industry have generally been based on the economic competitiveness of this source of power relative to alternatives. Economic competitiveness is a necessary condition for the growth of geothermal industry, but it is not sufficlent for maintaining the growth. In order to Identify these sufficlent conditions, it is necessary to undertake a study of the regional socioeconomic impact of the exploitation of geothermal resources. Reglonal socloeconomic analyses will provide a basis for anticipating the demands for capital, labor, materials, land, water, etc. Geothermal resources tend to get overlooked in national socioeconomic analyses because they represent less than $2 \%$ of the domestic reserves of energy. However, at the regional level, this resource can be very signiflcant. (For instance, geothermal resources could supply up to $10 \%$ of the energy used in California). Therefore, it is appropriate to develop a regional socioeconomic impact model.

At present, very little work has been reported in this area, such as the Impact of geopressure development in the Corpus Christi area of Texas or the impact of hydrothermal development in some parts of the Imperial Valley.

If improvements in the existing local infrastructure (e.g., road, power lines, housing stock, etc.) are required for geothermal energy development, particularly in remote locations, the rate of 
development may be significantly slowed. Constraints on the rate of development may also be imposed by the expansion required in supportive industries (e.g., drilling rig companies, heat exchanger manufacturers, etc) particularly if conditions encourage a sudden increase in geothermal exploitation activity. Relatively little research into these topics appear to have been conducted thus far. Although it is not a major priority at this time, identification of potential bottlenecks in a particular region would provide a valuable planning aid. 


\section{NUGGET ANALYSIS}

The committee evaluated past and ongoing work in the economics area. The attached nugget analyses summarize the research results and assess the relevance of the research to commerclalization. Commercialization was defined to Include all activities associated with the production and distribution of geothermal energy to the consumer.

Because of lack of immediately available information, the committee was not able to evaluate: (1) the regional economics work at New Mexico State, (2) the work on stochastic analyses at JPL, and past work at (3) SRI and (4) EPRI. The work on industry analyses at MIT was not included, since it was judged to be more relevant to the marketing area than to the economics area. Forelgn geothermal experience is also relevant to the comercialization process, but the committee did not have time to evaluate past work in this area.

\section{LIST OF NUGGETS}

\section{Applied Physics Laboratory (APL)}

AN ECONOMIC ANALYSIS OF POTENTIAL GEOTHERMAL SITES ON EASTERN COASTAL PLAIN: VOL. I \& II

AN ECONOMIC ANALYSIS OF POTENTIAL GEOTHERMAL SITES ON EASTERN COASTAL PLAIN: VOL. III (ongoing)

EG\&G (INEL)

GEOTHERMAL POWER ECONOMICS

Energy Resources Co.

GEOTHERMAL VENTURE ANALYSIS 
Geothermal Resources Council

DIRECT UTILIZATION OF GEOTHERMAL ENERGY: A SYMPOSIUM MITRE

A COMPARATIVE ANALYSIS OF ENERGY COSTING METHODOLOGIES

ANALISIS OF GEOTHERMAL ENERGY DEVELOPMENT SCENARIOS (1976)

BENEFIT/COST ANALYSIS OF DGE UTILIZATION TECENOLOGY BRANCH R\&D PROJECTS ( 1 Jan - 31 Dec 1978)

GEOTHERMAL EXPLORATION AND RESOURCE ASSESSMENT (GERRA) R\&D PROGRAM BENEFIT/COST ANALYSIS

PROSPECTS FOR IMPROVEMENT IN GEOTHERMAL WELL TECHNOLOGY AND THEIR EXPECTED BENEFITS

SITE-SPECIFIC ANALYSIS OF GEOTHERMAL DEVELOPMENT (1978)

Pacific Northwest Laboratory (PNL)

GEOCOST MODEL

GEOCITY MODEL

GEOTHERMAL ENERGY POTENTIAL FOR DISTRICT AND PROCESS HEATING APPLICATIONS IN THE U.S. (BNWL-2311, August 1977)

NEAR-TERM GEOTHERMAL ENERGY SUPPLY CURVES AND THE IMPACTS OF TECENOLOGY (PNL-2753, September 1978)

TAX POLICY STUDIES (1977)

THE ECONOMICS OF GEOTHERMAL ELECTRICITY GENERATION FROM HYDROTHERMAL RESOURCES (March 1976) BNWL-1989

THE POTENTIAL BENEFITS OF GEOTHERMAL ELECTRICAL PRODUCTION FROM HYDROTHERMAL RESOURCES (June 1976) BNWL-2001

ECONOMIC AND SYSTEMS STUDIES OF GEOTHERMAL ENERGY SUPPLY

THE FEASIBILITY OF USING GEOTHERMAL ENERGY TO PROVIDE POWER FOR THE REDUCTION OF ALUMINUM

ECONOMIC ANALYSIS OF POTENTIAL USES OF GEOTHERMAL ENERGY IN AGRICULTURE 
THE COST OF MEETING ENVIRONMENTAL CONTROL STANDARDS FOR GEOTHERMAL POWER PLANTS

NON-MARKET CONSIDERATIONS IN GEOTHERMAL POWER PLANT SITING

University of Pennsylvania

FORECASTING CAPITAL INVESTMENT BEHAVIOR FOR GEOTHERMAL ELECTRIC POWER INDUSTRY 
TITLE :

SUBJECT AREA:

PRINCIPAL

INVESTIGATOR:

CONTRACTOR:

TELEPHONE:

OBJECTIVE:

RESULTS :
AN ECONOMIC ANALYSIS OF POTENTIAL GEOTHERMAL SITES ON EASTERN COASTAL PLAIN: VOL. I \& II

VOL I: REVIEW OF RECENT ENERGY PRICE PROJECTION

VOL II: GEOTHERMAL PRODUCTION AND DISTRIBUTOR COSTS

\section{R. WEISSBROD}

JOHN HOPKINS UNIVERSITY (APL)

$301-338-7180$

ESTIMATE THE COST OF SUPPLYING GEOTHERMAL ENERGY FOR DIRECT APPLICATION ON THE EASTERN COASTAL PLAIN

(1) The primary competitive fuel for geothermal will be oil, while the ceiling price will be that of electric space heating. Projections for these prices in 1990 are in the range of $\$ 6.0$ to $\$ 7.50$ for oil and $\$ 11.50$ to $\$ 15.00$ per million BTU's for electricity in 1978 dollar values.

(2) Geothermal Cost Findings

(a) Although hotter resources are generally preferable, if a cooler resource requires significantly less ( $20 \%$ to $50 \%$ ) pumping energy, it may be more attractive.

(b) Market saturation levels above about $60 \%$ result in modest reduction in costs as saturation increases, while levels below $50 \%$ raise costs significantly as saturation falls off.

(c) A change in climate as measured is a difference of about 1000 degrees days results in a change of about $\$ 1.00$ per million BTU's for low temperature, $\left(150^{\circ} \mathrm{F}\right)$, moderately deep $\left(5,000^{\prime}\right)$ resources.

(3) Average Cost Mode1

To aid in the preliminary evaluation of the impact of specific resource and economic conditions, the GRESS model provides an interactive system which is highly flexible, both in the range of possible inputs and in the level of detail for results. The model may be accessed by remote terminal and a user can quickly become familiar with its method of operation. 
RESULTS (CONT'D)

(4) Space Heating Requirements

Space heating demands within an urban area may vary by several fold and perhaps by an order of magnitude. Housing census data and supplemented commercial information can be used to identify the spatial configuration of different levels of space heating energy requirements and hence the 11 kely cost of servicing these requirements through a district heating system.

RELEVANCE TO COMMERCIALIZATION NEEDS:

(1) The GRESS model provides a means of assessing the preliminary data or economic and resource conditions and of estimating the sensitivity of costs to changes in such factors as drawdown in the well due to pumping, the level of risk assigned by lending institutions, and the spatial concentration of potential demand.

(2) The energy density maps Identify the portion of a particular area which can most economically be served and suggest the change in costs as the system expands to encompass the remaining portion. 
TITLE:

AN ECONOMIC ANALYSIS OF POTENTIAL GEOTHERMAL SITES ON EASTERN COASTAL PLAIN: VOL III (on going)

SUBJECT AREA: VOL III - - PRODUCTION COST-SPACE HEATING REQUIREMENTS IN THE SOUTH ATLANTIC AND MARKET SHARE ESTIMATES

PRINCIPAL

INVESTIGATOR: WILLIAM BARRON

CONTRACTOR: JOHN HOPKINS UNIVERSITY (APL)

TELEPHONE: $\quad 301-338-7180$

OBJECTIVE: $\quad$ ESTIMATE PRODUCTION COST FOR THE SOUTH ATLANTIC AND DEVELOP ENERGY DENSITY MAPS FOR THE MAJOR URBAN AREAS IN THIS REGION; CONSTRUCT INTERACTIVE MODEL WHICH ACCOUNTS FOR TIME STREAM OF COSTS AND REVENUES UNDER DIFFERING PENETRATION RATES; AND DEVELOP THE MARKET SHARE ESTIMATES BASED ON CHARACTERISTICS OF THE HOUSING MARKET AND THE COST OF GEOTHERMAL ENERGY.

RESULTS :

(1) Market share estimates for study area.

(2) Modify geothermal resource characteristics in response to new information.

(3) Time stream model which represents various cost assumptions and demand assumptions.

RELEVANCE TO COMMERCIALIZATION NEEDS:

(1) Provides a better planning environment for potential developers and government agencies.

(2) Tool for DOE field offices in developing local estimates.

Refer to Map of Atlantic City Residential and Commercial Space and Hot Water, Figure 2-1. 
Atlantic City Residential and Commercial Space and Hot Water

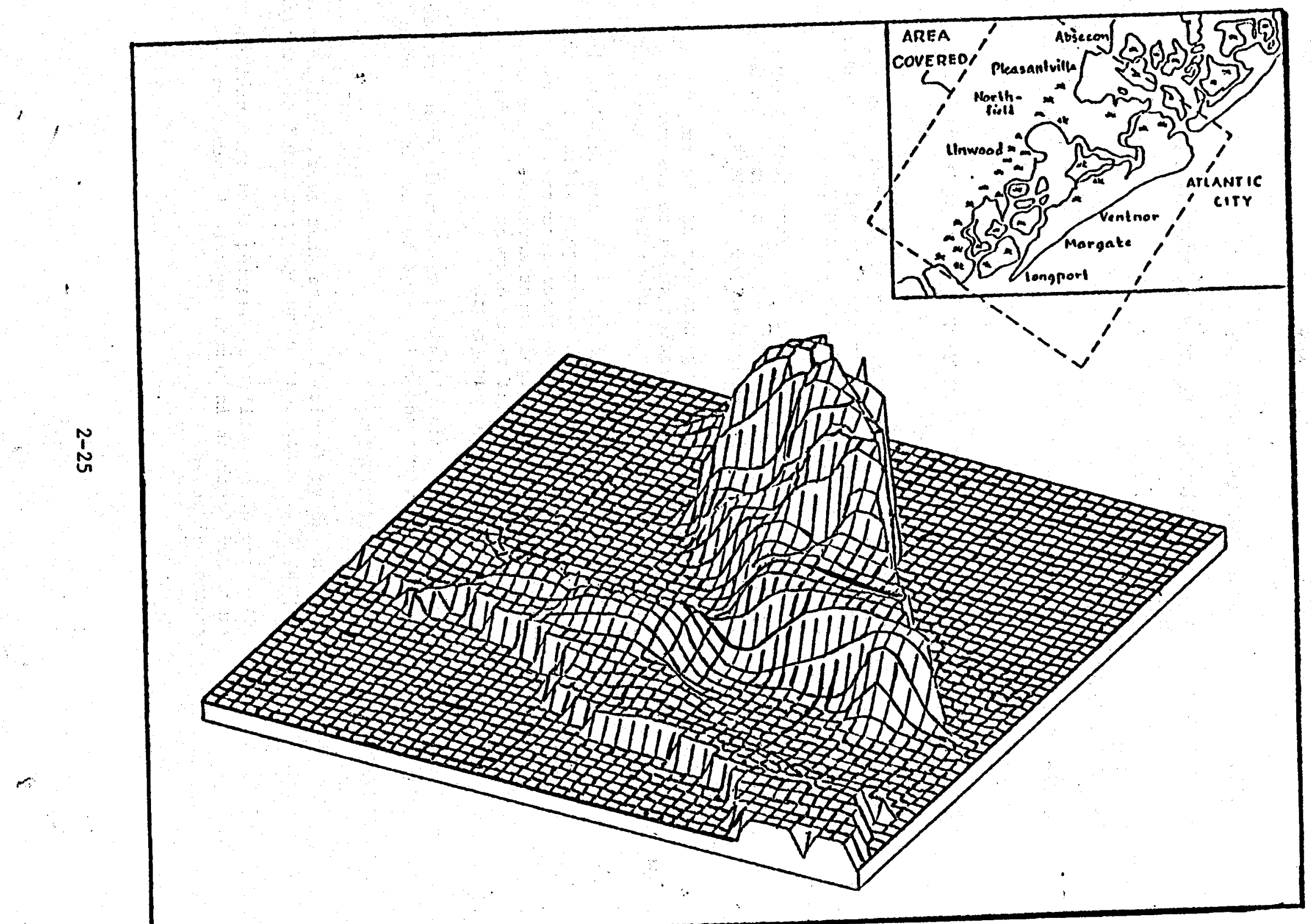

FIGURE 2-1 
TITLE :

SUBJECT AREA:

PRINCIPAL INVESTIGATOR:

CONTRACTOR:

TELEPHONE :

OBJECTIVE :

RESULTS:
A PRESENTATION OF THE TITLE SUBJECT TO A GROUP OF UTILITIES

\author{
T.W. LAWFORD
}

EG\&G IDAHO

$208-526-1844$

TO PRESENT THE ECONOMICS OF GEOTHERMAL POWER TO ELECTRIC UTILITIES.

(1) The capital cost of geothermal power plants and field is competitive with conventional power plants for reservoir temperatures above $450^{\circ} \mathrm{F}$.

(2) Power generation costs for flash steam plants are competitive with those of conventional plants for reservoir temperatures as $10 \mathrm{w}$ as $350^{\circ} \mathrm{F}$.

(3) Binary geothermal plants extend the range of competitive power generation costs to reservoirs as cool as $300^{\circ} \mathrm{F}$, if good well flowrates can be obtained.

(4) The fact that geothermal power can be added in $50 \mathrm{MW}(\mathrm{e})$ increments, with power generation costs that are competitive with conventional sources in 5001000 MWe sizes, has significant advantages for many utilities with respect to investment and matching capacity growth to load growth.

(5) The "so called risks" of geothermal power are not catastrophic, but add only 5-10\% to the cost of power.

RELEVANCE TO COMMERCIALIZATION NEEDS :

(1) The above results indicate that geothermal power from some resources has advantages for utilities today.

(2) Some of the utilities hearing this presentation expressed interest in acquiring more information on geothermal power. 
TITLE:

SUBJECT AREA:

POLICY ANALYSIS AND SITE-SPECIFIC ANALYSES DESCRIBING THE BARRIERS FOR IMMEDIATE COMERCIALIZATION OF GEOTHERMAI ELECTRIC POWER PRODUCTION, AND PROPOSED SOLUTIONS.

PRINCIPAL

INVESTIGATOR: JOHN B. EDWARDS

CONTRACTOR: N. ENERGY RESOURCES CO., INC.

TELEPHONE : $\quad 617-661-3111$

OBJECTIVE: TO CONDUCT POLICY ANALYSIS AND SITE-SPECIFIC ANALYSES DESCRIBING THE BARRIERS FOR IMMEDIATE COMMERCIALIZATION OF GEOTHERMAL ELECTRIC POWER PRODUCTION, AND PROPOSED SOLUTIONS.

RESULTS :

(1) Stimulation of interest among the development companies, utilities, financial institutions and government agencies.

(2) A report in the form of a prospectus.

RELEVANCE TO COMERCIALIZATION NEEDS:

Will be evaluated upon completion of the study. This is a study that relates more to impediments analysis than to venture analysis.

* Work in progress. 
TITLE:

SUBJECT AREA:

PRINCIPAL

INVESTIGATOR \& CONTRACTORS :

OBJECTIVE :

RESULTS :
DIRECT UTILIZATION OF GEOTHERMAL ENERGY: A SYMPOSIUM*

\section{DIRECT APPLICATIONS}

MOST OF THE PAPERS WERE DERIVED FROM THE PRDA's COVERING ENGINEERING AND ECONOMIC STUDIES FOR DIRECT APPLICATIONS.

TO ASSESS TECHNICAL AND ECONOMIC FEASIBILITY OF VARIOUS DIRECT APPLICATIONS OF GEOTHERMAL ENERGY.

Most of the papers dealt with applications of geothermal energy in the agribusiness area. All applications were technically feasible and conceptual engineering designs were developed for each application. Most of the applications were also judged to be economically feasible under certain conditions; however, because of wideranging differences in assumptions and analytical methods, direct comparisons between the various applications could not be drawn without more detailed study.

RELEVANCE TO COMMERCIALIZATION NEEDS:

The conditions for using geothermal energy in several direct applications were described, thus allowing the conditions for economic feasibility to be defined.

* Held January 31 - February 2, 1978 at San Diego, California; Geothermal Resources Council, P.0. Box 1033, Davis, California, 95616. 
TITLE :

SUBJECT AREA:

PRINCIPAL

INVESTIGATOR:

CONTRACTOR:

TELEPHONE :

OBJECTIVE :

RESULTS :
A COMPARATIVE ANALYSIS OF ENERGY COSTING METHODOLOGIES

METHODOLOGY AND MODELS

EL-SAWY, JOHN LEIGH, AND RANVIR TREHAN

MITRE

$703-827-6000$

TO DELINEATE THE SOURCES OF DIFFERENCES IN ESTIMATES OF GEOTHERMAL ELECTRIC POWER COSTS.

(1) Differences in financial cost methodology can lead to wide range of cost estimates for the same physical plant:

-38 mills 1 Kwhr - $69.7 \mathrm{mills} / \mathrm{kwhr}$ - for low temperature (1.e. $190^{\circ} \mathrm{C}$ ) geothermal power plant

-26.9 mills 1 Kwhr - $51.7 \mathrm{mills} / \mathrm{kwhr}$ - for high temperature (1.e. $\left.230^{\circ} \mathrm{C}\right)$ geothermal power plant

(2) Main sources of cost differences are:

- Treatment of inflation

- Use of mixed and current dollars

- Inapproprlate Interest rate

- Revenue inflation

- Treatment of reinvestment

- Differences in fixed charge rates

- Capital investment schedule

- Discounting convention

RELEVANCE TO COMMERCIALIZATION NEEDS :

Indicates need for standard energy costing methodology for valid comparison of alternative competing energy options. 
TITLE:

SUBJECT AREA:

PRINCIPAL

INVESTIGATOR:

CONTRACTOR:

TELEPHONE :

OBJECTIVE :

RESULTS :
ANALYSIS OF GEOTHERMAL ENERGY DEVELOPMENT SCENARIOS (1976)

ANALYSES OF PRODUCTION COST AND MARKET PENETRATION

RANVIR K. TREHAN, ET.AL.

MITRE

$703-827-6000$

DETERMINE LIKELY FEASIBLE GEOTHERMAL DEVELOPMENT (IN A MACRO SENSE)

- Geothermal not competitive economically without significant cost reductions.

- Likely long-term growth rate $\leq 15 \%$ P.A. Because of constraints on market penetration, resource lifetime, land leasing, drill rigs.

- Likely short-term development $\leq 4800$ MWE by 1985 .

RELEVANCE TO COMMERCIALIZATION NEEDS:

Provided basis for market studies. 
TITLE:

SUBJECT AREA:

PRINCIPAL

INVESTIGATOR:

CONTRACTOR:

TELEPHONE:

OBJECTIVES :

RESULTS:
BENEFIT/COST ANALYSIS OF DGE UTILIZATION TECHNOLOGY BRANCH R\&D PROJECTS (1 Jan - 31 Dec 1978)

COST EFFECTIVENESS ANALYSES

DANIEL J. ENGINGH, V.T. NGUYEN AND H.S. DHILLON

MITRE

$7.03-827-6000$

- PROVIDE A UNIFORM BASIS FOR EVALUATING THE PROBABLE IMPACTS OF DGE TECHNOLOGY R\&D PROJECTS ON TEE COST OF ELECTRICITY FROM U.S. LIQUID-DOMINATED GEOTHERMAL PROSPECTS.

- estimate the LIKELY TECHNICAL AND ECONOMIC IMPACTS OF 113 R\&D PROJECTS IN THE THREE R\&D PROGRAMS OF THE UTILIZATION TECHNOLOGY BRANCH.

- The 113 Profects were found to fall into 56 product-oriented groups.

- The R\&D projects are likely to save between $22 \%$ to $43 \%$ of the cost of constructing and operating electric generating systems at U.S. liquid-dominated geothermal prospects.

- This savings is on the order of $\$ 2.4$ to $\$ 4.7$ billion over the years $1979-2000$ across the DGE hydrothermal development scenario for 27 specific sites.

- Most of the R\&D products will be ready for use by 1985.

- The benefit/cost ratio for the entire UTB Program falls in the range of $37: 1$ to $73: 1$.

- The potential impacts of DGE technology R\&D efforts on hydrothermal electric costs are summarized in Tables 4-7. Note: Potential benefits and cost savings are summed across 27 U.S. Ilquid-dominated geothermal prospects. The percentage impacts at any individual prospect might fall above or below the indicated range, and will depend on the estimated physical characteristics of the prospect. 
RESULTS CONT'D: Further analysis is needed to estimate and sum the impacts at specific sites.

RELEVANCE TO COMMERCIALIZATION NEEDS:

- Commercialization dates for R\&D products have been identified. Can be used to schedule activities with manufacturers.

- Where there is a threshold cost of power for prospect development, the analysis indicates which R\&D projects contribute the most to cost reduction.

- A similar analysis would be useful for direct applications. 
TITLE:

GEOTHERMAL EXPLORATION AND RESOURCE ASSESSMENT

(GERRA) R\&D PROGRAM BENEFIT/COST ANALYSIS

SUBJECT AREA: COST EFFECTIVENESS ANALYSIS

PRINCIPAL

INVESTIGATOR: H. DHILLON, A. EL-SAWY, S. GOLDSTEIN, T. MEIDAV AND R. PFANDOTUN

CONTRACTOR: MITRE

TELEPHONE: $\quad 703-827-6000$

OBJECTIVES : (1) TO DETERMINE COST EFFECTIVENESS OF GERRA R\&D PROGRAM

(2) TO EXAMINE RELEVANCE OF GERRA R\&D PROGRAM TO GEOTHERMAL INDUSTRY NEEDS

RESULTS :

(1) GERRA R\&D Program appears to be cost effective $(B / C<20)$.

(2) Industry survey analysis indicated need for two-phase R\&D Strategy

- In near-term (pre-1985) assure utilities about the reliablitty of geothermal fuel resources with more emphasis on reservolr assessment, confirmation and engineering models and techniques.

- Attalnment of long-term goal (Year 2000) requires continuation of basic research almed at discovering new resources

(3) Effective GERRA R\&D budget range is $(2.08-6)$ million dollars per year for five years, is the optional near $\$ 4.0 \mathrm{M}$.

RELEVANCE TO COMMERCIALIZATION NEEDS:

Indicated industry perceived effectiveness and need for improvement on current GERRA R\&D Program to facilitate early commercialization of hydrothermal resource. 
TITLE :

SUBJECT AREA:

PRINCIPAL

INVESTIGATOR:

CONTRACTOR:

TELEPHONE:

OBJECTIVES :

RESULTS :
PROSPECTS FOR IMPROVEMENT IN GEOTHERMAL WELL TECHNOLOGY AND THEIR EXPECTED BENEFITS.

ANALYSES OF PRODUCTION COST

E. FRIEDMAN AND A. EL-SAWY

MITRE

$703-827-6000$

(1) TO ESTABLISH RANGES FOR EXPECTED DRILIING RED IMPACT ON COST SAVING IN GEOTHERMAL DRILLING

(2) TO PROVIDE QUANTITATIVE GUIDANCE FOR DESIGN OF A RESEARCH PROGRAM TO IMPROVE DRILLING PERFORMANCE.

(1) Expected savings from improvement in conventional drilling technology accounts for 46 percent reduction In drilling cost by 1987, and exceeds those from novel drilling technology which accounts for an additional 26 percent drilling cost reduction by 1990 , (see Figure 1)

(2) Only $20 \%$ of the geothermal sites (included in the power-on-line scenario) have specific drilling problems that require specific solutions.

(3) Research need are dominated by the requirement for new metal and elastomer materials with better high temperature performance.

(4) Information transfer and commercialization could be enhanced by government-sponsored initlatives in:

- Development of testing equipment, procedures and facilities appropriate to the geothermal environment.

- Encouraging fleld testing of new technology with minimal risk to commercial drillers.

RELEVANCE TO COMMERCIALIZATION NEEDS:

(1) Indication of areas of drilling technology improvement that could lead to substantial drilling cost savings.

(2) Indication of government initiatives that could enhance technology transfer and commercialization.

Refer to FIGURE 2-2. 


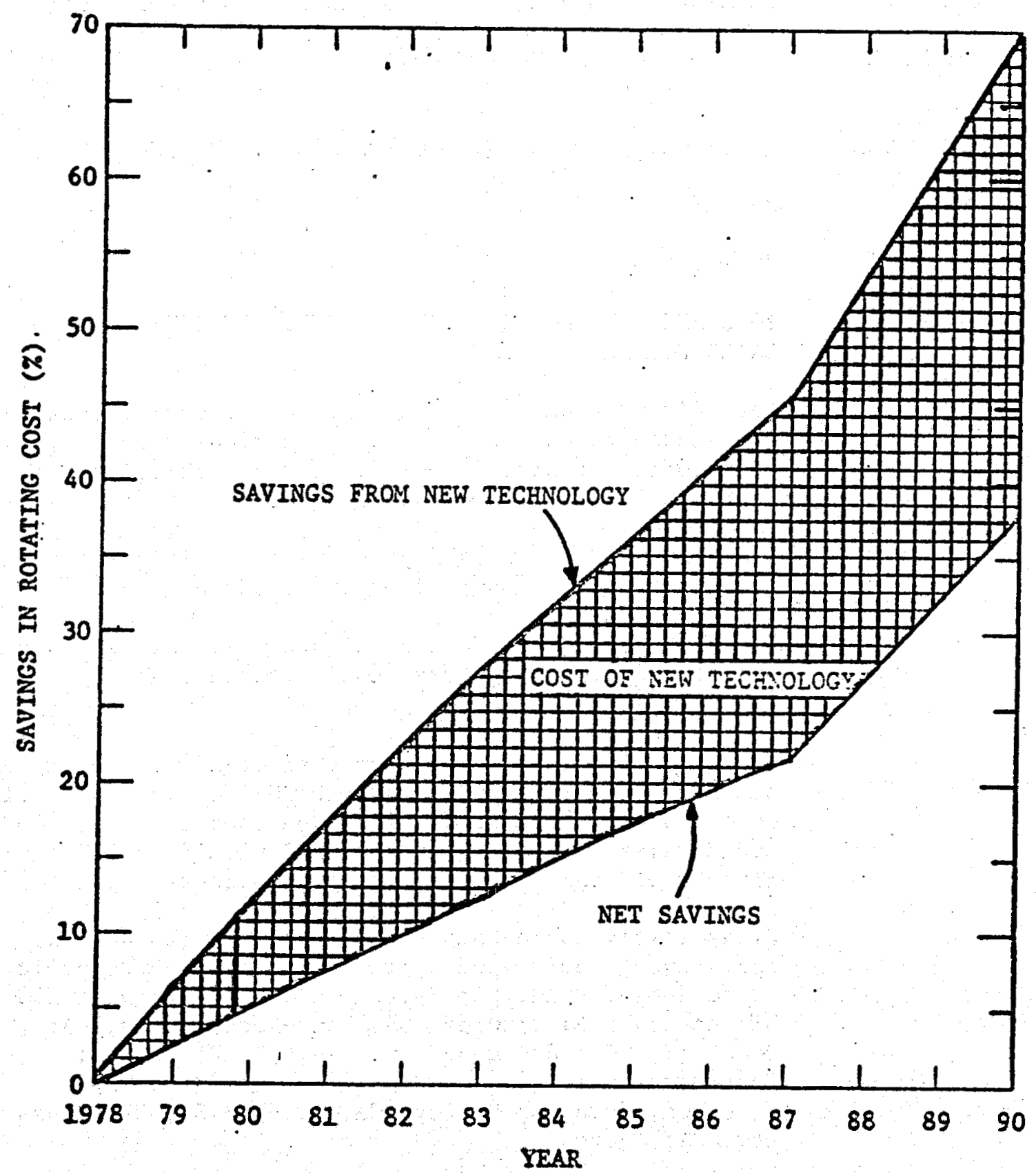

FIGURE 2-2

GROSS AND NET SAVINGS BY YEAR 
TITLE:

SUBJECT AREA:

PRINCIPAI

INVESTIGATOR:

CONTRACTOR:

TELEPHONE :

OBJECTIVE :

RESULTS :
ANALYSES OF PRODUCTION COSTS

J. LEIGH, A COHEN, W. JACKSON AND R. TREHAN

MITRE

$703-827-6000$

TO EXAMINE ECONOMIC COMPETITIVENESS OF SITES POSTULATED FOR DEVELOPMENT BY DGE

Both R\&D program to reduce costs and fiscal incentives are needed to make geothermal economically competitive at majority of sites studied, thereby achieving one necessary condition for development.

Projected R\&D advances may reduce electricity costs from geothermal resources by 15 to $30 \%$ by 1990 .

Fiscal incentives (20\% depletion allowance, expensing intangible drilling costs) could reduce costs by another 10 to $30 \%$.

Without R\&D or incentives, only about $25 \%$ of the generating capacity postulated in the DGE Geothermal Development Scenario is projected to be competitive. R\&D could raise this to about $50 \%$; $R \& D$ plus fiscal incentives could raise the percentage to about $15 \%$.

Sites likely to be competitive by 1990 with R\&D and incentives are (in rough order of projected economic preference); Puna, HI; Salton Sea, CA; Roosevelt H.S., UT; Lassen, CA; Brawley, CA; Mono-Long Valley, CA; Coso H.S., CA; Steamboat Springs, UT; Heber, CA; East Mesa, CA; Bedwawe, NV; Valles Caldera, NM; Vale, OR; Surprise Valley, CA; Brady H.S., NV; Glass Mt., CA; Thermo, UT.

Report includes detailed site-specific data base.

RELEVANCE TO COMMERCIALIZATION NEEDS:

Provides support for broad-based program. Indicates sites which may be competitive already, sites which may be made competitive by present policies and sites which may still be too expensive. 
TITLE :

SUBJECT AREA:

PRINCIPAL

INVESTIGATOR:

CONTRACTOR:

TELEPHONE :

OBJECTIVE:

RESULTS :
GEOCOST MODEL*

ELECTRICITY PRODUCTION COST MODEL

C.H. BLOOMSTER

PACIFIC NORTHWEST LABORATORY

509-942-4357, FTS $444-4357$

DEVELOP AN ECONOMIC MODEL FOR GEOTHERMAL ELECTRICITY PRODUCTION WHICH COULD ESTIMATE ELECTRICITY GENERATION COSTS AS A FUNCTION OF RESOURCE CHARACTERISTICS, POWER PLANT TECENOLOGY, THE TAX POLICIES, AND FINANCIAL STRUCTURE.

(1) A model was developed which met the objectives, and is available to users through the Argonne Code Center.

-(2) The model has been validated against a number of geothermal electric plants including The Geysers, Cerro Prieto, and Ahuachapan.

RELEVANCE TO COMMERCIALIZATION NEEDS :

Provides a planning tool for both potential developers and government agencles to evaluate the economics of geothermal power plants as a function of variations in technology, resource characteristics, tax policies, and financial structure. 
TITLE:

SUBJECT AREA:

PRINCIPAL

INVESTIGATOR:

CONTRACTOR:

TELEPHONE:

OBJECTIVE:

RESULTS :
GEOCITY MODEL*

DIRECT APPLICATIONS/DISTRICT HEATING

C.H. BLOOMSTER

PACIFIC NORTHWEST LABORATORY

509-942-4357, FTS444-4357

TO DEVELOP A MODEL TO SIMULATE GEOTHERMAL DISTRICT HEATING AND PROCESS HEATING.

(1) The GEOCITY Model was developed.

(2) Cost of heating high density urban is $50 \%$ of cost of heating a suburban development.

(3) Verification of the model with case studies from Oregon, Iceland and other sites.

(4) Costs most sensitive to climate, fluid temperature, population, and population density.

RELEVANCE TO COMMERCIALIZATION NEEDS:

(1) Provides a planning tool for potential developers and government agencies. Code is available through Argonne Code Center.

(2) Economic feasibility of district heating and process heat applications can be evaluated rapidly for wide variety of resource characteristics, climatic conditions, and demographic characteristics.

(3) Model has been applied to several district and process heating studies. 
TITLE:

SUBJECT AREA: DIRECT APPLICATIONS

PRINCIPAL INVESTIGATOR

CONTRACTOR:

TELEPHONE:

OBJECTIVE:

RESULTS : August 1977) APPLICATIONS.
GEOTHERMAL ENERGY POTENTIAL FOR DISTRICT AND . PROCESS HEATING APPLICATIONS IN THE U.S. (BNWL-2311,

\author{
C.H. BLOOMSTER AND L.L. FASSBENDER
}

PACIFIC NORTHWEST LABORATORY

509-942-4357, FTS444-4357

TO EVALUATE RELATIONSHIP BETWEEN CHARACTERISTICS OF GEOTHERMAL ENERGY RESOURCES AND DIRECT HEATING APPLICATION. TO ESTIMATE THE SUPPLY AND DEMAND FOR DIRECT

(1) Geothermal heat may be transmitted economically over long distances on a large scale ( $>24$ " diameter pipe). On a large scale, the cost is under $\$ 0.10 /$ million BTU/mile and may be as low as $\$ 0.02 /$ million $\mathrm{BTU} / \mathrm{mile}$. Load factor and temperature are two important determinates of cost.

(2) Prellminary estimate of Western U.S. supply curve.

(3) Preliminary estimate of Western U.S. demand curve.

(4) Estimate of how much of current demand could be supplied under various prices. Most hlgh population density urban demands could be met competitively with geothermal resources up to 50 miles distant.

(5) Could meet most suburban residential demands when alternate fuel prices exceed $\$ 8 /$ million BTU. (\$8/) million BTU is equivalent to electric heating at 27 mills/KWh or natural gas heating at $\$ 0.50 /$ therm.)

(6) Process heating demands (above $100^{\circ} \mathrm{C}$ ) can be met economically from distances out to 30 miles from h1gher temperature $\left(>140^{\circ} \mathrm{C}\right)$ geothermal resources.

(7) Most of Western U.S. population resides within 40 miles of geothermal sites. 


\section{RELEVANCE TO COMMERCIALIZATION NEEDS:}

(1) Demonstrates geothermal hot water can be transported economically over distances up to 50 miles.

(2) Demonstrates large demand exists in Western U.S.

(3) Demonstrates large population can be supplied at competitive prices. 
TITLE:

SUBJECT AREA:

PRINCIPAL INVESTIGATOR:

CONTRACTOR:

TELEPHONE :

OBJECTIVES :

RESULTS :
NEAR-TERM GEOTHERMAL ENERGY SUPPLY CURVES AND THE IMPACTS OF TECHNOLOGY (PNL-2753, September 1978)

GEOTHERMAL PRODUCTION COSTS AND RESOURCE AVAILABILITY FOR ELECTRIC AND NONELECTRIC APPLICATIONS

\section{L.L. FASSBENDER AND C.H. BLOOMSTER}

\section{PACIFIC NORTHWEST IABORATORY}

509-942-4361; FTS $444-4361$ and $942-4357$; FTS $444-4357$

(1) ESTABLISH NEAR-TERM SUPPLY CURVES FOR BOTH ELECTRIC AND NONELECTRIC APPLICATIONS OF THE IDENTIFIED HIGH-TEMPERATURE AND INTERMEDIATE-TEMPERATURE HYDROTHERMAL RESOURCES IN THE U.S.

(2) EVALUATE THE IMPACTS OF INDIVIDUAL TECHNOLOGY IMPROVEMENTS AND ALSO THE CUMULATIVE IMPACTS OF COMBINATIONS OF TECHNOLOGICAL ADVANCES ON THE SUPPLY CURVES.

(1) Near-term supply curves were derived for electric and nonelectric applications.

(a) There are about 9000 MWe centuries of geothermal electrical potential avallable at a cost of power below $100 \mathrm{mills} / \mathrm{kWh}$, based on the use of current state-of-the-art technology.

(b) The potential for space heating using the identified high-temperature and intermediatetemperature hydrothermal resources in the U.S. Is about 500 quads.

(c) The potential for process heating using the same resources is about 250 quads.

(2) The binary cycle has the potential to double the supply of geothermal power that can be produced for $100 \mathrm{mills} / \mathrm{kWh}$ or less.

(3) Advanced downhole pumps should be capable of decreasing the cost of power from resources with subsurface temperatures $<180^{\circ} \mathrm{C}$ by more than $20 \%$.

(4) Reducing dr1lling costs by $25 \%$ should decrease the cost of power by $20-40 \%$, depending on the resource temperature. 
(5) Through a combination of significant technological advances, all of the identified hydrothermal resources could become competitive with conventional energy sources for electric power production.

RELEVANCE TO COMMERCIALIZATION: NEEDS:

(1) Near-term supply curves are useful aids in program planning and budgeting. Cost-effectiveness analyses of alternative program plans and policies can be undertaken by comparing potential shifts in the supply curves.

(2) Significant reductions in the cost of power (over $70 \%$ ) may be achieved with technology improvements.

(3) The range of values experienced or expected for most of the significant factors which have an economic influence on the utilization of geothermal energy are summarized. 
TITLE:

SUBJECT AREA: See Title

PRINCIPAL

INVESTIGATOR:

CONTRACTOR:

TELEPHONE:

OBJECTIVES:

RESULTS:

TAX AND REGULATORY POLICY STUDIES (1977)*

$$
\text { C.H. BLOOMSTER }
$$

PACIFIC NORTHWEST LABORATORY

509-942-4357; FTS 444-4357

TO EVALUATE THE IMPACT OF ALTERNATIVE TAX AND REGULATORY POLICIES ON THE COST AND PENETRATION OF GEOTHERMAI ELECTRIC POWER.

The Individual effects of different tax and regulatory policies were evaluated. Considered were: Depletion Allowance, Intangible Drilling Costs, Electric Investment Tax Credits, and Accelerating Licensing Procedures.

RELEVANCE TO COMMERCIALIZATION NEEDS:

Provided a quantitative basis for evaluating tax policles which were formulated for the Energy Tax Act.

* (The analyses were described in letter reports sent to Randy Stephens). 
TITL:

SUBJECT AREA: ANALYSES OF ELECTRICITY PRODUCTION COSTS

PRINCIPAL,

INVESTIGATOR: C.H. BLOOMSTER

CONTRACTOR:

TELEPHONE :

OBJECTIVES :

RESULTS :

PACIFIC NORTHWEST LABORATORY

509-942-4357; FTS $444-4357$
THE ECONOMICS OF GEOTHERMAL ELECTRICITY GENERATION FROM HYDROTHERMAL RESOURCES (March 1976) BNWL-1989

(1) TO ANALYZE THE SENSITIVITY OF GEOTHERMAL POWER COSTS TO SEVERAL RESOURCES AND OPERATIONAL PARAMETERS.

(2) TO DETERMINE THE OPTIMUM COMBINATION OF PLANT SIZE AND POWER CYCLE FOR SPECIFIED RESOURCE PARAMETERS.

(1) The most important resource parameters are: Resource Temperature, Well Cost, Well Flow Rate, We11 Life, and Non-Condensible Gas Content.

(2) The most important operational parameters are Plant Size, Load Factor, Power Plant Efficiency and Well Spacing.

(3) The cost of the power plant, while significant in the power generation cost, is not especially sensitive to resource temperature.

(4) The optimum geothermal plant size is small, in the 50-200 MWe range.

RELEVANCE TO COMMERCIALIZATION NEEDS:

(1) This study showed small plant sizes (50 MWe) plant sizes to be economic.

(2) This study determined that the most significant cost reductions could come from improvements in field costs. 
TITLE:

THE POTENTIAL BENEFITS OF GEOTHERMAL ELECTRICAL PRODUCTION FROM HYDROTHERMAL RESOURCES (June 1976) BNWL-2001

SUBJECT AREA:

PRINCIPAL INVESTIGATOR:

CONTRACTOR:

TELEPHONE:

OBJECTIVE :

RESULTS :

\section{ANALYSES OF MARKET PENETRATION}

C.H. BLOOMSTER AND R.L. ENGEL

PACIFIC NORTHWEST LABORATORY

509-942-4357; FTS 444-4357 TITION WITH NUCLEAR AND FOSSIL POWER.

(1) Eydrothermal geothermal power production will
TO EVAIUATE THE POTENTIAL PENETRATION OF GEOTHERMAL ELECTRIC POWER IN THE U.S. ENERGY SUPPLY, IN COMPEbe $2-4 \%$ of the national power production and $10-20 \%$ of Western U.S. power production by $1990(9,000-$ $17,000 \mathrm{MWe}$ ), with the lower end of the range being most likely.

(2) This is the energy equivalent of 100-200 million barrels of oll/year.

(3) Only the highest quality geothermal resources are competitive with conventional power sources.

(4) Future improvements in technology which lowers geothermal production costs only $35 \%$ would more than double the geothermal market penetration.

RELEVANCE TO COMMERCIALIZATION NEEDS:

The potential penetration of geothermal power produc-: tion into the U.S. energy market on an economically competitive basis was identified. 
TITLE :

ECONOMIC AND SYSTEMS STUDIES OF GEOTHERMAL ENERGY SUPPLY

SUBJECT AREA: GEOTHERMAL ELECTRIC AND NON-ELECTRIC APPLICATIONS

PRINCIPAL

INVESTIGATOR: C.H. BLOOMSTER AND L.L. FASSBENDER

CONTRACTOR: $\quad$ PACIFIC NORTHWEST LABORATORY

TELEPHONE: $\quad$ 509-942-4357; FTS 444-4357

OBJECTIVES: (1) DETERMINE THE IMPACT OF TECHNICAL IMPROVEMENTS ON THE LONG TERM GEOTHERMAL SUPPLY CURVES.

(2) EVALUATE THE APPLICABILITY OF FOREIGN GEOTHERMAL EXPERIENCE TO THE U.S.

(3) DEVELOP AND PERFORM RELIABILITY ANALYSES OF GEOTHERMAL POWER PLANTS.

RESULTS:

Work is in progress -- results will be forthcoming to fulfill the objectives.

RELEVANCE TO COMMERCIALIZATION NEEDS:

(1) Provides guidance for R\&D planning.

(2) Provides economic and technical data on reservoir and plant operations at foreign geothermal sites.

(3) Evaluate the economic impact of uncertainties in plant and reservoir operations on geothermal power generation. 
TITLE:

SUBJECT AREA: INDUSTRY STUDIES

PRINCIPAL

INVESTIGATOR: W.I. ENDERLIN

CONTRACTOR: PACIFIC NORTEWEST LABORATORY

TELEPHONE: $\quad$ 509-946-2409

OBJECTIVES: (1) TO IDENTIFY SITES SUITABLE FOR THE GENERATION OF POWER AND REDUCTION OF ALUMINUM.

(2) TO ENCOURAGE THE ALUMINUM INDUSTRY TO CONSIDER THE USE OF GEOTHERMAL POWER FOR THE REDUCTION OF ALUMINUM.

RESULTS :

The results will seek to identify geothermal sites which are attractive for colocation of geothermal plants and aluminum reduction plants.

RELEVANCE TO COMMERCIALIZATION NEEDS:

A significant market for geothermal power may be indicated as a result of this study.

* This study is currently in progress. 
TITLE :

ECONOMIC ANALYSIS OF POTENTIAL USES OF GEOTHERMAL ENERGY IN AGRICULTURE

SUBJECT AREA: NON-ELECTRIC APPLICATIONS

PRINCIPAL

INVESTIGATOR: BRUCE CONE

CONTRACTOR: $\quad$ PACIFIC NORTHWEST LABORATORY

TELEPHONE: $\quad$ 509-942-4252; FTS $444-4252$

OBJECTIVE: TO EVALUATE THE ECONOMIC POSSIBILITY OF USING GEOTHERMAL ENERGY FOR SOIL WARMING.

RESULTS: (1) The economic possibility and water quality consideration for soil warming were investigated.

(2) Using existing technical, agrinomic, and economic data, the use of geothermal energy was uneconomic for all uses considered except peppers and tomatoes.

(3) The return of using geothermal energy for producing tomatoes was $\$ 2000 /$ acre.

RELEVANCE TO COMMERCIALIZATION NEEDS:

This study indicated some economic potential might exist for soil warming but additional work is needed to identify specific sites and crops where soil warming is economically feasible. 
TITLE :

SUBJECT AREA:

PRINCIPAL

INVESTIGATOR:

CONTRACTOR:

TELEPHONE :

OBJECTIVES :

RESULTS :
THE COST OF MEETING ENVIRONMENTAL CONTROL STANDARDS FOR GEOTHERMAL POWER PLANTS

ECONOMIC VALUATION OF GEOTHERMAL ENVIRONMENTAL IMPACTS
PACIFIC NORTHWEST LABORATORY

509-942-4355; FTS 444-4355

(1) DEVELOP GENERIC COST FUNCTIONS FOR ESTIMATING THE COST OF MEETING STANDARDS FOR HYDROGEN SULFIDE EMISSIONS AT ANY GEOTHERMAL SITE. DEMONSTRATE THE USE OF THE COST FUNCTIONS WITH A SITE-SPECIFIC CASE STUDY.

(2) DEVELOP GENERIC COST FUNCTIONS FOR ESTIMATING THE COST OF MEETING STANDARDS FOR WATERBORNE EFFLUENTS AT ANY GEOTHERMAL SITE. DEMONSTRATE THE USE OF THE COST FUNCTIONS WITH A SITE-SPECIFIC CASE STUDY.

(1) Cost functions for $\mathrm{H}_{2} \mathrm{~S}$ abatement were developed for 4 treatment techniques. Control costs for a site similar to The Geysers ranged from $1.2 \mathrm{mills} / \mathrm{kWh}$ for $50 \%$ abatement up to $2.4 \mathrm{mills} / \mathrm{kWh}$ for $99 \%$ abatement. Control costs are primarily a function of the $\mathrm{H}_{2} \mathrm{~S}$ concentration. The stretford $\mathrm{H}_{2} \mathrm{~S}$ removal process, backed up by the peroxide condensate treatment system, will achieve $99 \%$ abatement of $\mathrm{H}_{2} \mathrm{~S}$ emissions; this system appears to be the most cost effective of the available processes.

(2) Work on developing cost functions for waterborne effluents is in progress.

RELEVANCE TO COMMERCIALIZATION NEEDS:

Provides a generic methodology and a set of cost functions which can be used to estimate the cost of $\mathrm{H}_{2} \mathrm{~S}$ abatement 1iquid waste disposal for geothermal power plants. The methodology can be used to estimate abatement cost impacts among: (1) competing geothermal technologies, and (2) geothermal and other technologies avallable to the electric power industry. The commercial appeal for a given conversion technology vis-a-vis all other technologies 
will vary as environmental regulations vary. The important point is that environmental regulations do not have identical effects on all conversion technologies. 
TITLE :

SUBJECT AREA :

PRINCIPAI

INVESTIGATOR: J.W. CURRIE

CONTRACTOR:

TELEPHONE :

OBJECTIVES :

RESULTS :
NON-MARKET CONSIDERATIONS IN GEOTHERMAL POWER PLANT SITING

ECONOMIC VALUATION OF GEOTHERMAL ENVIRONMENTAL IMPACTS
PACIFIC NORTHWEST LABORATORY

509-942-4355; FTS 444-4355

DEVELOP: (A) METHODOLOGY FOR PREDICTING THE MAGNITUDE OF NON-MARKET IMPACTS OF DEVELOPMENT AT GEOTHERMAL SITES, (B) A SET OF ECONOMIC MEASURES OF THE VALUE OF THOSE IMPACTS VERSUS THE VALUE OF CURRENT USE TO SOCIETY, AND (C) ESTIMATES OR RANKINGS OF THE OVERALL ATTRACTIVENESS OF INDIVIDUAL GEOTHERMAL SITES FOR COMMERCIALIZATION IN TERMS OF NON-MARKET COSTS.

Work scheduled to commence during FY79, extending into 1981.

RELEVANCE TO COMNERCIALIZATION NEEDS:

Provides a framework for objectively evaluating and ranking geothermal sites in terms of non-market costs. This information coupled with power production costs gives the full social cost of geothermal power production at any site. This information coupled with estimates of alternative regional power costs will strongly suggest which sites have the most commercial potential. 
TITLE:

SUBJECT AREA: INVESTMENT ANALYSIS

PRINCIPAL

INVESTIGATOR: T.A.V. CASSEL AND R.H. EDELSTEIN

CONTRACTOR:

TELEPHONE:

OBJECTIVE:

RESULTS: THERMAL ELECTRIC POWER INDUSTRY. FIELDS AND POWER PLANTS.
FORECASTING CAPITAL INVESTMENT BEHAVIOR FOR GEO-

UNIVERSITY OF PENNSYLVANIA - PHILADELPEIA, PA. 19174

MODELING IN GEOTHERMAL ELECTRIC POWER INVESTMENT BEHAVIOR TO ESTIMATE THE CONDITIONAL PROBABILITY OF REGIONAL CAPITAL INVESTMENT IN GEOTHERMAL WELL

(1) Identification of investment criterla for both resource producers and the electric power producers.

(2) The main investment criteria for the resource producer are:

- Rates of return exceeding the minimum acceptable corporate rate of return for major producers.

- For small producers the rate of return threshold is closely related to their marginal, cost of capital.

- Time frame for development; the shorter the better.

- Ultimate net present value: A minimum expected capacity of $50 \mathrm{MW}$ for 20 years is a necessary condition for investment.

- Extent and complexity of institutional barriers, (e.g. land lease, permitting, resource usage conflicts, licensing requirements, etc).

- Marketability

- Public image (as to safety and environmental desirability). 
- Joint venturing.

- Technical constraints (e.g. Depth \& geology of reservoir, quality of reservoir fluid, and fluid flow rate).

- Logistical constraints (e.g., availability of manpower, or drill rigs).

(3) The main investment criteria for the electric power producers are:

- Electric energy cost competitiveness.

- Baseload growth forecast.

- Public image.

- System reliability

- Investment risk

- Cash flow

- Institutional barriers

- Technical constraints (e.g., cooling water requirements and availability

- Logistical constraints (e.g. turbine availability

(4) Two different methods of ranking investment opportunities are recommended as follows:

- For the resource producer (assumed to be a profit maximizing firm) investment opportunitles are ranked according to their net present value.

- For the externally regulated electric utility firm the ranking is based on Joskow \& Mishkin Equation which calculates the likelihood (probab1lity) that a given energy technolgoy will best satisfy the above listed utility investment criteria. 
RELEVANCE TO COMMERCIALIZATION NEEDS:

This preliminary report was prepared, in its final form, shortly after contract award. This study may provide a framework for geothermal development market expectations. 


\section{PLANNING FOR DEVELOPMENT "SCENARIOS" \\ SECTION 3}

3-1 

PLANNING FOR DEVELOPMENT - "SCENARIOS"

TO: GEOTHERMAL RESOURCE MANAGER, DOE/RA

FROM: Planning Documents - Assessment Group

SUBJECT: Report of assessment of past planning effort and recommendations for the future effort.

This is the report of the group assembled $29 \mathrm{Jan}$ through $9 \mathrm{Feb}$, 1979, to revlew and assess the utility of documented planning effort, sometimes termed "Scenarios," and to make recommendations in regard to future planning effort.

Committee Members:

C. Fredrickson JPL

J. Close EG\&G

S. Goldstein Metrek/MITRE

F. Paddison APL/JHU

Extensive consultation with staff members of the Department of Energy (DOE)/Assistant Secretary for Resource Applications (RA), assisted the group.

\section{Summary}

Planning efforts have been conducted by many people. Without exception they have assisted in the development of either quantitative estimates of geothermal potential, increased the awareness of the potential of geothermal energy in an area, and identified both opportunities not realized and problem areas requiring action. Further, they represent a detalled documentation of the substance of DOE, state and local program efforts to date. 
It is most significant that these efforts have introduced geothermal energy to a broad spectrum of people at an earlier time than would have happened otherwise. This is particularly true in the cases of the preparation of the strawman prospectuses (Table 1). Although there has been considerable varlation in the approach and substance of the different planning efforts, they are all judged to have been useful in supporting the mission of the Division of Geothermal energy.

This report recognizes four primary types of planning effort and outcomes. These are:

a. Establishment of quantitative estimates of the total development potential of geothermal hydrothermal energy;

b. Collation of estimates and plans for use as preparatory marketing tools in commercialization activities;

c. Identification of legal, institutional, financial, and technology developments or task that the Federal government, either singularly or in consonance with state and local bodies, can undertake to expedite the use of geothermal energy; including appropriate time-phasing among required Federal and local activities;

d. Documentation of multi-agency agreements and schedules.

All four of these forms of effort contribute to the orderly process of resource application, as well as the development of requirements for technology development by DOE(ET) and therefore should be continued.

As with all planning there must be recognized users of the data. We suggest that users of planning information are as follows:

a. In the case of the estimates of total development potential 
of geothermal energy, the users are the analysts who organize the ensemble of electric and non-electric areas in prioritized sequence, develop a series of possible DOE development strategies, and suggest an optimum allocation of Federal resources. The planning scenarios for all known electric generation resources are avaliable, as is a methodology for strategy analysts. In the case of the non-electric resources the planning data are not complete and the methodology does not exist. Since the development of non-electric applications is so significant for displacing fossil fuel, we suggest a strong emphasis be put on completing the planning data for most geothermal direct use areas, development of and application of a methodology to evaluate direct applications strategies.

b. The commercialization support activity prepares a marketing tool to be used by local interested groups and those agents of DOE that foster marketing. Although it is necessary to continue these efforts for electric applications, it is important to emphasize the non-electric applications for industry process heat and especially for space conditioning, which is a harder market to penetrate. Appendix E discusses why space conditioning applications require special treatment.

c. Finally, the user of the issues or problems list are primarily the Department of Energy and local governmental bodies. These data have not in the past been collected, sifted, and analyzed in the most useful ways to promote either action taken within DOE to resolve issues or to raise the issues with the Interagency Coordinating Council if required action is outside the Department of Energy. These data would appear to be even more significant than ever with the recent organizational separation of RA and DGE. 


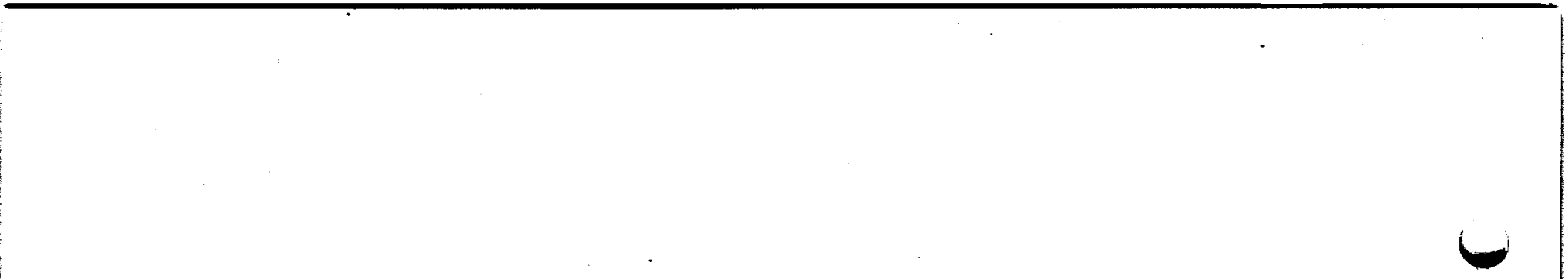




\section{Effort and Documents Reviewed}

The Planning documents which have been reviewed are grouped by regions and are as follows: (Note: the geopressured regions are not included by direction).

\section{Region}

California/Hawail

Washington, Oregon, Alaska

Rocky Mts, Basin and Range

Eastern United States (all states east of the Rocky Mts and Including Puerto Rico)

\section{Organizations Contributing}

JPL, SDC, SAI, MITRE/Metrek and the Futures Group

OIT, MITRE/Metrek

EG\&G, APL/JHU, MITRE/Metrek and NMEI

APL/JHU and EG\&G

\section{Types of Planning Documents}

Table 3-I lists in summary form the types of planning documents that either have been or are considered useful for geothermal development. Appendix $A$ is a narrative description of each of these documents with an assessment of: the purpose which they may serve, the user, and how frequently they should be updated or revised. Figure 3-1 1llustrates information paths in scenario type commercialization aids.

The documents shown in Table $3-I$ and discussed in Appendix $A$ are the main types of planning effort currently in use and which were avallable to the committee for review. However, in the future there may be other types of effort necessary and useful to Resource App11cation.

\section{The Review of Prior Efforts}

Appendix $B$ is a detalled review of each planning document ava11able to the Assessment Group. 
Áll planning documents were not available at the time of the workshop, and accordingly the assessment of these efforts had to be done subsequently. This report when finally published will be complete. It should be noted that the planning documents vary considerably in detail, one from the other, however, they all have served a purpose. The known electric resources have been analyzed, for the most part, without considering limitations due to size of the local market. This approach is judged to be adequate at this time, since other constraints, some of which are cited, will apparently limit development before the size of the market does.

In the case of the non-electric resource, a substantial portion of the United States has had some planning estimates of resource size; however, many of these have not been analyzed with the market size as a limitation. Further, DOE has not agreed upon a basis for the estimation of the market demand for and the form of direct utilization. It is therefore understandable that these planning efforts vary considerably in their assessment of the resource and the size of the market. A common methodology is suggested and much of this effort should be reviewed.

In Appendix $B$ there is a narrative description of the effort and a statement about its significance to commercialization. The table after the statement indicates the extent and type of documentation for each effort.

\section{Suggested Future Effort}

Appendix 3-C discusses programmed and proposed future efforts. Several comments are in order. 
It is shown in Table C3-I and C3-II, that no future efforts have been scheduled in California. The intention is, that this will be done by the state. Hawail's situation is similar.

Planning scenarios to complete a national geothermal potential estimate are shown for deep sedimentary basins and fault dominated areas in the eastern United States, refinement in the Pacific southwestern states, and North Dakote. It is recommended that a methodology be developed to aggregate the estimates of projected geothermal development, and that the resource areas then be rank-ordered.

The site prospectus has been prepared for very few places, 1.e., the San Luis Valley and the Delmarva Peninsula. Strawnan scenarios for South Dakota were an early version of the site prospectus. Many more (1.e., 17) sj.te prospectuses are proposed. It is suggested that inftially, site frospectuses should be prepared only in those states that have not received a PON award.

Finally, it is recommended that the individual action items, 1.e., problems or unresolved issiues, developed in planning scenarios and the site prospectus be collected, distilled, and either acted upon or shelved.

International Use of Geothermal Energy and Majiketing of United State :echnology

Appendix D contains a briet: discussion of suggested planning efforts related to an International assessment of the state of geothermal technology, preparatory to the U.S. marketing efforts. 
The Need for Additional Planning Effort to Assist the U.S. on Hydrothermal for Space Heating

Appendix E is a brief description of the special problems of commercializing geothermal energy's use for space heating. This appendix notes that the site prospectus planning document is a mental device to surface and call attention to these problems, and their solutions.

\section{Guidelines for Developing Site Prospectuses}

Appendix F presents guidelines used for 10 states in the Rocky Mountain and Basin and Range areas. The difference in approach in the eastern U.S. is discussed.

\section{Alternative User-Oriented Scenarios}

Appendix $G$ is a brief summary suggesting the utility of useroriented planning scenarios that may be applicable in more than one resource area. 
TABLE 3-I

\section{SCENARIO CATALOGUE}

\section{SCENARIO}

USES

1. Market

Asse $\overline{\text { ssment }}$

Resourcel

User Match

2. Planning

Scenario

Scoping

Program \&

Strawman

$P$ lanning

for states

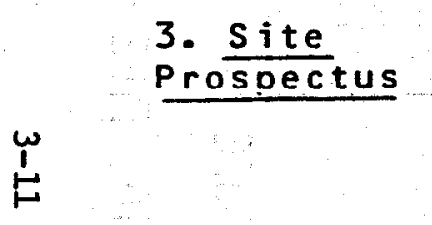

4. Geothermal Site

Schedule

\begin{tabular}{l} 
5. Imple- \\
mentation \\
\hline Plan
\end{tabular}

Local mar-

ketina,

identify

specific

problemsl

opportuni-

ties, key

events.

players

\section{Site}

specific

project

\section{Multi- agency \\ agreement \\ and \\ schedule: \\ financial}

implication. scheduling
PARTICIPATION open data files, estimate potential.

Flags key performance

targets, barrierse

performance measures

Identify key events,

olayers \& require-

ments

Schedules key actions/ events

Identifies and schedules key milestones
DOE, USGS

States

DOE, USGS

$S$ tates

\section{COMMENTS}

Monitor shows

measure of

change

To date, most

lack well identi-

fied interstage

decision points

Federal, Indicates extensive

State, interaction.

Local, \&

Private

Federal,

State,

Local, \&

Private

Federal,

State,

Local govt.
Many examples avaf1able - considerable variations in detail.

Primarily interm-governmental documents not received by Assesment Group. 


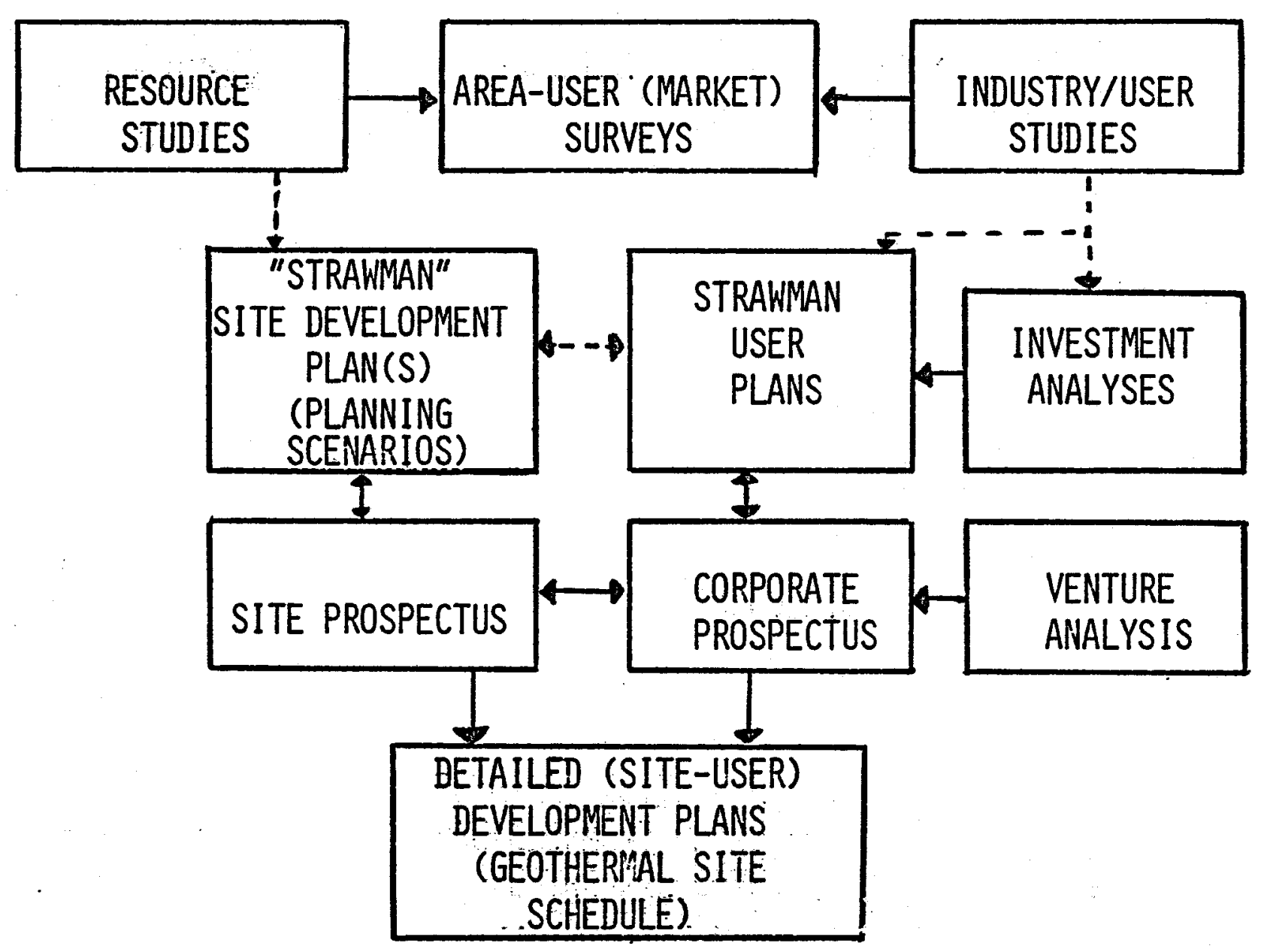

FIGURE 3-1

INFORMATION FLOWS IN "SCENARIO" TYPE COMMERCIALIZATION AIDS 


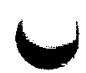

APP ENDIX 3A

DISCUSSION OF VARIOUS TYPES OF

PLANNING TJOLS IN SCENARIOS

$3 A-1$ 


\section{DISCUSSION OF VARIOUS TYPES OF PLANNING TOOLS IN SCENARIOS}

\section{Market Assessment}

The simplest and usually the first step in Geothermal planning normally consists of the identification of a resource area and its co-location or proximity to a market. A broad quantitative measure of the resource and its type usually is included together with an estimate of the market size, from which it can be judged whether or not the resource is stressed by the potential market. This type of planning tool establishes broad initial quantitative estimates of the entire geothermal potential, of identified resources, and the extent of their utilization by existing or projected markets in that area.

\section{Primary Uses}

Is there a resource and use $r$ match?

Recognizes site for consideration

Establishes or identifies quantitative upper bound of resource potential

Establishes or identifies quantitative upper bound for existing market use of resource potential

Quantitative tool for guiding programmatic decisions and funding strategies

Users - DOE

Up-Dating Requirements - Orce written, the market assessment probably does not need to be revised, but rather a planning scenario should be written. 


\section{Planning Scenario}

The second step in geothermal planning; this document is in greater detail than the market assessment document, and is usually written for an area. However, it can be written for a specific site. This document quantifies, to the extent possible, the resource magnitude, and the market in place. The projected development of the market with time is included. The possible utilization of the resource by the existing and projected market vs. time is shown together with the significant step required. The precedence relation of each significant step is usually shown. The catalogue of tasks serves the following purposes:

a. Develops general types and quantity of effort required by DOE, the state, local agencies and the private sector. The aggregation of these data when measured against existing and projected equipments, tools and technical manpower, determine whether or not the DOE program on geothermal energy development as posed by these plans is possible, or whether the stock of these tools and manpower must be increased appropriately.

b. It lists the general level and types of effort required by other Federal agencies. In some cases this required effort is rather specific. Accordingly this list justifies and particularizes specific tasking to be considered by the Interagency Coordinating Council.

c. In addition to cataloguing the tasks required, the planning scenario identifies significant steps and actions required to achieve 
the projected power-on-line goals. Conversely it allows a quantitative assessment of the consequerces of missing the schedule set forth for a key step or milestone. Ir addition it allows the assessment in a quantitative sense of a new incentive or other inducement to consider utilization of geothermal energy.

The planning scenario is normally a more detailed evaluation of the resource potential and the narket utilization of the resource than the earlier market assessment.

The users of this document are Federal Agencies and States. These up-date requirements, since those documents should be used to establish goals and measure the status of progress against these goals, these scenarios should be updated periodically.

How many of these documents are required? There should be scenarlos for every known resource area in the United States if we are to establish national goals and measure progress. Appendix B lists those that have been completed and Appendix C lists those recommended in the future.

The Strawman - A Varient o: the Planning Scenario

The planning scenario can be written with a minimum of help from the state and local groups and is a consequence if care is not exercised its existence can cause resentment by the state. The Strawman scenario, on the other hand, is used where it is desirable to educate state and local personnel as to how to apply geothermal energy in their specific area, and to eli:it their interest and response. 
Their reaction to the usage and economics proposed in the Strawman sets the stage for writing the next form of planning tool the Site Prospectus, and most significantly to determine in their judgement whether or not the Strawman plan is complete and sensible. The Planning Scenario does not necessarily have to include economic considerations, whereas the Strawman must, to allow a sensible dialogue to occur.

\section{Primary Use}

Education of State, local and private individuals;

Elicit response in regard to economics, environment, risk, and other questions;

Identify hurdles that Federal, State, 1ocal and private individuals must address, either collectively or individually, e.g. legislative to permit geothermal use of water as a "beneficial use;"

Prepare for writing site prospectus;

Start development of local infrastructure;

Initiate marketing in area;

Users - DOE, state and local groups

Updating requirements - needs revision only when better data or additional information becomes available.

\section{The Site Prospectus}

The Site Prospectus of a geothermal area is written to inform and aid in the application of geothermal energy. The prospectus is done with the assistance of many organizational entities and it is not important who has primary responsibilities for the drafting of 
the plan, just as long as it is clearly defined that someone does. Typically, either the state or an agent for the Department of Energy drafts the Prospectus with active participation from a variety of others including the private sector. Although the Site Prospectus will vary from area to area and depend upon the type of application, it will include many or all of the following subjects:

a. A resource description;

b. An estimate of the resources energy potential;

c. Detailed discussion and charting of plant design, construction, testing, and office and individuals responsible for each, and the powers-on-line goals as a function of time for near term and foreseeable longer term users;

d. Reservoir engineering and management;

e. Applications engineering and economic considerations;

f. Geothermal development issues and requirements, offices, and individuals involved:

environmental

legal

institutional

socioeconomic

technical;

8. Significant problems, or action items, requiring initiative by Federal, state or local bodies;

h. Others;

i. DGE, USGS or other programs and schedules for resource definition,

ii. State geothermal and environmental regulations, 
iii. Federal assistance programs available in the area,

iv. Area population and land use data and growth pattern,

v. Other forms of energy prospects and projections:

\section{Primary Use of Site Prospectus}

a. As a marketing tool, to inform and to involve all the prerequisite organizations, offices and individuals in charting all of the steps in the development of geothermal energy.

b. As a road map for geothermal application intended to facilitate and expedite the actual development; by identifying for all that is involved in detail and thereby providing the timing and designation of those responsible for action.

c. Identification in greater detail than previously possible the problem, actions, and research, development and engineering requiring effort by Federal, State or local bodies.

Potential Users - Everyone concerned with planning, legislation, permitting, reservoir management, environmental control, licensing, developer, energy technology.

Updating Requirements

Once written, this document only requires revision to bring it up-to-date with achievement of goals, new planned uses or developments, changes in legal, institutional or environmental issues or economic considerations. 


\section{Detailed Project Scheduling}

The very detailed schedulinis of a specific geothermal plant should not be part of the Site Prospectus. The Site Prospectus need only show the significant milestones distilled from a detailed project schedule. Accordingly detailed scheduling plans or networks are yet another planning tool. It is not obvious that the state or the Department of Energy play any role in or have any responsibility for these plans other than state regulatory bodies who must pass judgement on plans and engineering delails for permits and license. An exception to the above is the case of where the Department of Energy or its agents are involved in demonstration programs, and, accordingly, have a vital interest in the detailed program scheduling.

\section{Implementation P1ans}

This form is used by some for the category of plans just discussed in "Detailed Project Scheluling". However, in this document we will use it to designate an agreed upon plan and schedule between the Department of Energy, other hranches of government, the state and others as required. This document is not discussed further in this report. 
API'ENDIX 3B

THE REVIEW OF PRIOR EFFORTS

$3 B-1$ 


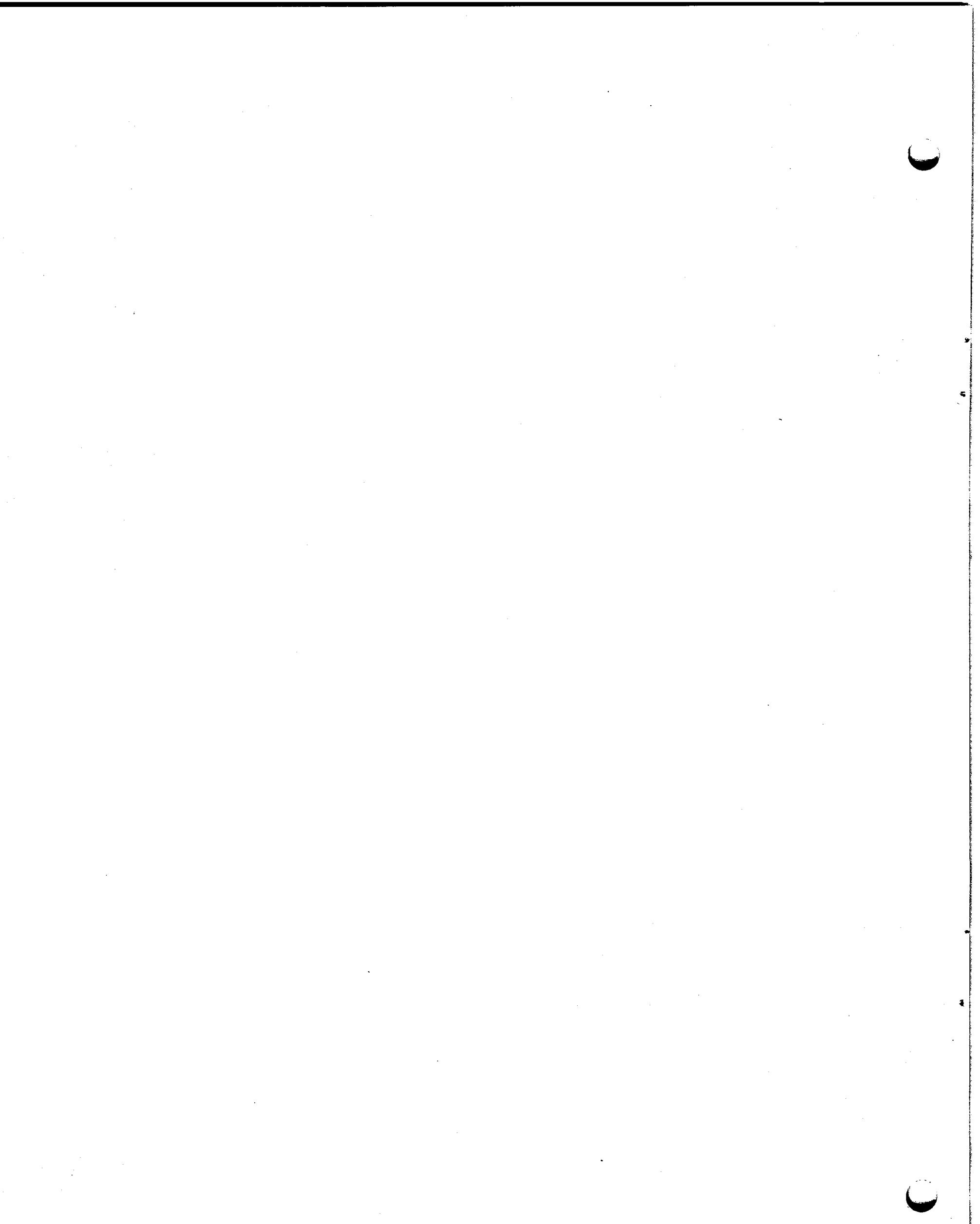


THE REVIEW DF PRIOR EFFORTS

This appendix contains a brief review of each document in a narrative form. In addition a tabular summary of all of the documents for a given area are included. In the case of an organization like APL/JHU where there are several documents of quite different character, there is a separate narrative summary discussing the objectives of each group. The following is an outline of the data presented: 
TABLE 3B-I

Summary and Evaluation of Planning Documents by Region

3B-9 Summary APL/JHU Eastern Planning Effort

3B-11 Brief Review Scenario - Southern Arkansas

3B-12 " " " - Atlantic Coastal Plain

3B-13 " " " - Western South Dakota

3B-14 " " " - Eastern Gulf Coastal Plain

3B-16 " " " - Narrative Community Heating in South Dakota

$3 B-17$

11

1

- Narrative Scenario of geothermal energy development by Oglala Sioux at Kyle, SD

$3 B-18$

11

"

- Brief Review of Scenario - Delmarva Peninsula

Rocky Mountains Basin and Range

3B-22 EG\&G Idaho, Inc. - Comercialization Plan - Utah, Idaho, and Oregon

3B-24 EG\&G Idaho, Inc. - Reglonal Hydrothermal Market Penetration Analysis - New Mexico, Arizona, Nevada, Utah, Colorado, Wyoming, Idaho, Montana, North Dakota, South Dakota.

3B-25 New Mexico Engineering Institute - Arizona, Nevada, New Mexico, Colorado, Utah.

S1x Northwestern States

3B-28 Detailed Development Scenario, Utah - State of Utah

3B-29 Geothermal Energy Development in Colorado - State of Colorado

3B-31 The District Space Heating Potential of Low Temperature Hydrothermal Geothermal Resources in the Southwestern United States - NMEI 
$3 \mathrm{~B}-32$

OIT Planning Scenarios for Alabama, Iowa, Montana, Oregon, Washington, Wyoming.

\section{Pacific Region}

3B-40 Pacific Region Federal Geothermal Commercialization Plan Arkansas, Washington, Oregon, California, Hawail - SF/ Operations Office

3B-42 Analysis for Accelerating the Development of Geothermal Resources in California - JPL

3B-44 Direct Use Overview for Hawal1 - Total Use Scenarios for Puna, Hawail - SAI

3B-46 Total Use Scenario for Imperial Valley - SAI

3B-47 Regional Systems Development for Geothermal Energy Resources Pactfic Region (California \& Hawaii) - SDC

3B-48 A Technology Assessment of Geothermal Energy Resources Development - The Futures Group

3B-50. Analysis of Geothermal Energy Development Scenarios MITRE/Metrek

3B-52 Site-Specific Analysis of Geothermal Developments - MITRE/ Metrek

3B-54 Key to maps which show Scenario coverage.

3B-56 Maps which show Scenario coverage 


\section{EASTERN PEGION \\ PLANING EFFORTS}

$3 B-9$ 


\section{SUMMARY - APL/JHU PLANNING EFFORT}

The following are reports documenting Eastern

U.S. geothermal planning efforts:

1. The Coastal Plain in Southern Arkansas, QM-77-129-1

$10 / 77$

2. The Atlantic Coastal Plain, QM-77-129

3. The Madison Aquifer in Western South Dakota, QM-77-129-1 11/77

4. The Eastern Gulf Coastal Plain, QM-77-129-3 2/78

5. Potential Application of Madison Formation Waters for Community Heating in South Dakota, QM-78-042R

6. Geothermal Energy Development of the Oglala Sious at Kyle, South Dakata, QM-78-266

7. A site prospectus for the development of Geothermal Energy on the Delmarva Peninsula. Draft - 14 Sept - Oct -Jan, QM-78-191

\section{DESCRIPTION AND SIGNIFICANCE}

The first four scenarios were bar chart type showing tasks and their time phasing versus resource magnitude. Market potential was indicated and cumulative direct application power-on-line was shown. The only resource area potentially able to produce electric power from hydrothermal geothermal is the Eastern Gulf Coast. The capability is shown along with direct use. These were written for DOE/DGE top-down planning and as such are significance in establishing national goals, and DOE funding stratagies. 
The fifth and sixth scenarios are the strawman type, i.e., how to use geothermal energy in South Dakota. These are narrative reports written to inform, educate, and elicit response from community groups and the state. This type of scenario is significant to marketing and outreach. This effort spawned four of the PON and PRDA's awarded in South Dakota.

The seventh scenario is a narrative type written in cooperation with the local agencies, i.e., significant in initiating local action and as a marketing tool.

This final effort has spawned five PRDA proposals plus a workshop run by State Planning agency for county and other interested personnel. The following sections are detailed reviews of each document. 
TITLE: The Coastal Plain in Southern Arkansas, A Scenario for Geothermal Energy Development in the Eastern U.S., QM-77-129-1, October 1977

APPLICATION: Direct

PRINCIPAL

INVESTIGATOR: E.L. Fox, APL - John Hopkins University

ABSTRACT: There are many indicators of geothermal potential in Arkansas. The report calls attention to the need for geologic investigation of the state. The potential resource in the Southern Coastal Plain part of the state is quantified and the market estimated and direct use power-on-1ine versus time is estimated. The major steps to this power production are listed and time phased.

SIGNIFICANCE: This document is useful in scoping the geothermal potentisl and the market of the area, and thereby contributing to the establishment of national geothermal development goals. Further the document informs state and local groups of geothermal potential. 
TITLE: Atlantic Coastal Plain, A Scenario for Geothermal Energy Development on the Eastern U.S., QM-77-129-1, October 1977

APPLICATIONS : Direct

PRINCIPAL INVESIGATOR: W.J. Toth, APL - John Hopkins University

ABSTRACT: Based on preliminary geophysical data from VPI for eight potential resource areas on the Atlantic Coastal Plains, resource magnitudes were approximated and compared with those of potential markets for geothermal energy. An initial ordering of the eight areas performed according to a modified MITRE ranking procedure and this order was assumed in time-phasing resource development activities. The scenario calls out three phases in development: resource exploration, assessment and engineering, a utilization demonstration phase, and finally a commercialization phase which is stimulated by the successful execution of the first two. Power-on-line estimates assume the third phase is essentially complete in the 1995 - 2000 time frame and about $140 \times 10^{12} \mathrm{Btu} / \mathrm{yr}$ was the market-limited upper bound.

SIGNIFICANCE: These broad early scenarios are useful in identifying the potential of a resource area and the extent of the market in that area. These data are in turn useful in comparative analysis of one area vis-a-vis another resource area, as well for general planning of DOE funding strategies and allocation of technical and other resources, and finally contributing to the establishment of national geothermal development goals. Finally, this form of scenario is useful in informing State personnel of their potential. 
TITLE :

The Madison Limestone Aquifer in Western South Dakota, A Scenario for Geothermal Development in the Eastern U.S., QM-77-129-2, November 1977

APPLICATION: Direct

PRINCIPAL

INVESTIGATOR: C.A. Shipley, APL - John Hopkins University

ABSTRACT: A bar chart type of scenario for Western South Dakota development of the Madison for community space heating. The resource magnitude is estimated together with the potential space heating and industrial agricultural market. Power-on-line versus time is estimated. Market size is not adequate to stress resource. Steps necessary to achieve power-on-line projections are outlined.

SIGNIFICANCE: Scenario useful in scoping size of resource area and its contribution in time and magnitude for displacing fossil fuel. Significant in arriving at Federal funding strategy and informing state of potential, and in contributing to the establishment of national geothermal development goals. 
TITLE :

Eastern Gulf Coastal Plain, A Scenario for Geothermal Development in the Eastern U.S., QM-77-129-3, February 1978

APPLICATION: Direct and Electric

PRINCIPAL

INVESTIGATOR: W.J. Toth, APL -John Hopkins University

ABSTRACT: $\quad$ Based on information supplied by the USGS and the state geologists in Mississippi, Alabama, and Florida, three types of geothermal resources may be exploitable in the area. Preliminary resource magnitude estimates were made and compared to the sizes of potential markets in each resource area. A modified MITRE ranking procedure was employed to assist in time-phasing development activities for each resource. The scenario identifies phases in the complete development and commercialization of these resources: a resource exploration, assessment and engineering phase to characterize the resource(s), a utilization demonstration phase to provide technical and economic viability, and a commercialization phase which is stimulated by successes in the first and second. One unique aspect of this scenario with respect to other APL scenarios is the possibility of electrical generation in this area, if the resources prove out. Power-on-line estimates show a leveling off of direct use with market saturation in the 2010 to 2015 time frame and a steadily increasing electrical generation utilization that levels off quickly after 2020.

SIGNIFICANCE: These broad early scenarios are useful in identifying the potential of a resource area and the extent of the market in that area. (This scenario in particular identifies an additional area where resources may exist to permit the generation of electricity). These data are in turn useful in comparative analys is of one area vis-a-vis another resource area and as well for general planning of DOE funding strategies and a1location of technical and other resources. Finally, this form of scenario is useful in informing state Personnel of their potential, and in contributing to the establishment of national geothermal development goals. 
TABLE 3B-II

SCENARIO EVALUATION

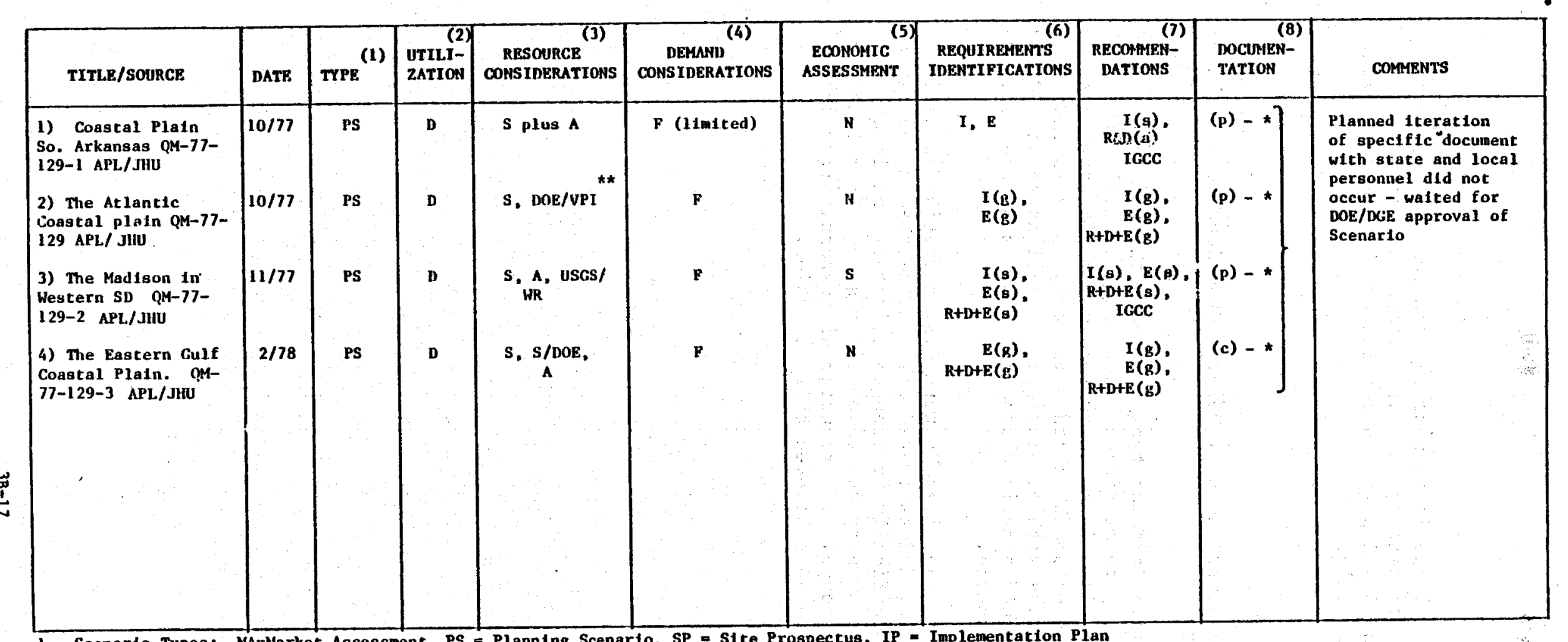

1. Scenarto Types: MA=Market Assessment, PS = Planning Scenario, SP = Site Prospectus, IP = Implementation P1an

2. Utilization: E = Electric, D = Direct Applications

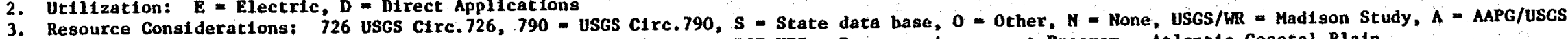
Ceothermal File, S/DOE = DOE/Sta Co.

4. Demand Considerations: P = Paper Study, F = Fleld Work (outreach)

5. Economic Assessment: $=$ = Generich $\&$ Development Engineering, (g) $=$ generic, (s) = site-specific

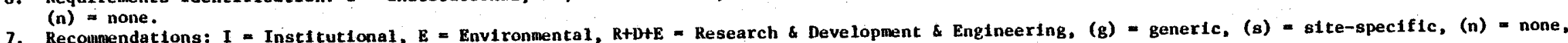
IGCC = Interagency Geotheral Coordinating Council.

8. Documentation of : $A=$ Assumptions, $M-$ Morels, $(c)=$ complete, $(p)=$ partial, $(n)=$ none.

* Documentation In report In IImited detail - detalls can be found in other documents.

** DOE/VPI - DOE Resource Definition Prog. (ICGG - Interagency Geothermal Coordinating Council. 
TITLE: Potential Application of Madison Formation Waters for Community Heating in South Dakota, A Scenario for Geothermal Development in the Eastern U.S., QM-78-042R, September 1978

APPLICATION: Direct

PRINCIPAL

INVESTIGATOR: R.A. Freeman and R.F. Meier, APL - John Hopkins University

ABSTRACT: This is a Strawman type of report that discusses community space heating as the most practical and early application of the hot waters underlying the western portion of South Dakota. The cost analysis indicates that towns with populations as small as about 300 persons could benefit economically by using the geothermal resource.

SIGNIFICANCE: This was the first Eastern U.S. narrative scenario that included estimated costs of geothermal energy and was specifically written to stimulate and inform the local community and to elicit response from local and state groups. The transfer of responsibility for the state has not allowed this iteration. 
TITLE: Geothermal Energy Development by the Oglala Sioux at Kyle, South Dakota, A Scenario for Geothermal Development in the Eastern U.S., QM-79-226, April 1978

APPLICATION: Direct

PRINCIPAL INVESTIGATOR: R.C. Eberhart and R.A. Freeman, APL - John Hopkins University

ABSTRACT: A Strawman type of narrative report discussing the use of the Madison waters for space heating for 125 existing houses and new high school, all in the Kyle, South Dakota area. A cost model for the community heating system is developed and costs are competitive with fossil fuels. The benefits of geothermal development are sited and recommendations made.

SIGNIFICANCE: This narrative-Strawman scenario was written to stimulate and inform the Oglala Sioux and the state of South Dakota and to elicit interest and response. Transfer of responsibility has not allowed iteration. 
TITLE :

A Site Prospectus for the Development of Geothermal Energy on the Delmarva Peninsula, QM-78-191, Draft Dated January 1979

APPLICATION: Direct

PRINCIPAL INVESTIGATOR: J.E. Tillman, APL - John Hopkins University

ABSTRACT: The approach utilized in the most recent, sitespecific scenario, done for the Delmarva Peninsula, has evolved from early scenarios which were designed strictly as planning tools for DOE. The Delmarva Scenario is a tutorial narrative aimed at providing interested local parties and agencies with enough background to facilitate their actions in developing an economic and environmentally acceptable resource in an efficient manner. Technical, environmental, legal, economic, and institutional information and hurdles to development are discussed. Since development initiative must stem from the local level, the scenario has been written in conjunction with state and local authorities. The resulting report is therefore a more useful instrument to them since it illustrates the relationship of the time phasing of their development plans with Federal programs to define the resource and thereby identifies the required initiatives to be taken at the state and local levels.

SIGNIFICANCE: The Delmarva Scenario is very significant to Eastern geothermal development. This form of scenario is marketing tool as well as a detailed road map of how to develop and apply geothermal energy in Delmarva. The process of cooperatively developing this plan with state and local personnel is just as important as the final document, however the document is a focus and point of reference in the future. 
TABLE 3B-III

SCEHARIO EVALATION

\begin{tabular}{|c|c|c|c|c|c|c|c|c|c|c|}
\hline TITLE/SOURCE & DATE & $\operatorname{TYPE}^{(1)}$ & $\begin{array}{l}\text { (2) } \\
\text { UTILI- } \\
\text { ZATION }\end{array}$ & $\begin{array}{c}\text { RESOURCE } \\
\text { CONSIDERATIONS }\end{array}$ & DEMAND $^{(4)}{ }_{\text {CONSIDERATIONS }}^{\text {Den }}$ & $\begin{array}{l}\text { ECONOMIC (5) } \\
\text { ASSESSMBNT }\end{array}$ & $\begin{array}{c}\text { (6) } \\
\text { REQUIREMENTS } \\
\text { IDENTIFICATIONS }\end{array}$ & $\begin{array}{c}\text { (7) } \\
\text { RECOMMEN- } \\
\text { DATIONS }\end{array}$ & $\begin{array}{l}\text { (8) } \\
\text { DOCUMEN- } \\
\text { TATION }\end{array}$ & COMMENTS \\
\hline $\begin{array}{l}\text { 5) Application of } \\
\text { Madison for community } \\
\text { heating South Dakota } \\
\text { QH-78-042R APL/JHU } \\
\text { 6) Geothermal Devel- } \\
\text { opment Oglala S1oux, } \\
\text { Kyle SD - QM-78-226 } \\
\text { APL/JHU }\end{array}$ & $4 / 78$ & SP & D & $\begin{array}{l}\text { S, A, USGS/ } \\
\text { WR } \\
\text { S, A } \\
\text { USGS/WR }\end{array}$ & $\mathbf{F}$ & $\mathbf{s}$ & $\begin{array}{r}I(s), \\
E(s) \\
R+D+E(s) \\
I G C C \\
\\
I(s), \\
E(s) \\
R+D+E(s)\end{array}$ & $\begin{array}{l}I(s), \\
E(s) ; \\
\text { S+D+E(s); } \\
I G C C \\
\\
I(s), \\
E(s), \\
\text { R+D+E(s), } \\
I G C C\end{array}$ & (c)* & $\begin{array}{l}\text { Strawman - Narrative } \\
\text { Scenarto Intended } \\
\text { to inforat and elictt } \\
\text { response - Responsi- } \\
\text { bility for SD trans- } \\
\text { ferred - No itera- } \\
\text { tion occured }\end{array}$ \\
\hline $\begin{array}{l}\text { 7) Ceothermal 1n } \\
\text { Del warva - QM-78-1.91 } \\
\text { APL/JHU }\end{array}$ & $1 / 79$ & SP & D & $\begin{array}{l}S_{,} A_{1} \\
\text { DOE/VPI }\end{array}$ & $\mathbf{F}$ & s & $\begin{array}{r}I(s), \\
E(s), \\
R+D+E(s)\end{array}$ & $\begin{array}{r}I(s) \\
E(s) \\
R+D+E(s)\end{array}$ & (c) & $\begin{array}{l}\text { State and local } \\
\text { people writing parts } \\
2 \text { scenarto }\end{array}$ \\
\hline
\end{tabular}

w 1. Scenar1o Types: MA = Market Assessment, PS - Planning Scenario, SP = S1te Prospectus, IP = Inplementation Plan

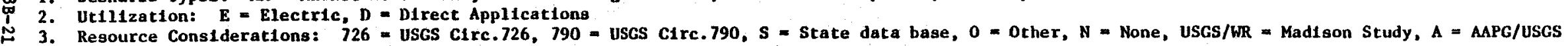
Geothermal FIle, S/DOE = DOE/State Coupled Resource Def. Program, DOE/UPI = Resource Assessment Program - Aclantic Coastal Plain.

4. Demand Considerations: $P$ - Paper Study, F = Field Work (outreach)

5. Economic Assessment: $G$ - Generic, $S=$ Site-specific, $\mid$ - Hybrid, Generic modifled by site-specific conditions, $N=$ None

6. Requirements Identification: I = Institutional, E = Environmental, R+D+E = Research \& Development Engineering, (g) = generic, (s) = sice-spec1fic $(n)=$ none.

7. Recomendations: $I=$ Institutional, $E=$ Envi conmental, $R+D+E=$ Research \& Development \& Engineering, (g) $=$ generic, (s) $=$ site-specific, ( $\mathrm{n}$ ) $=$ none, IGCC = Interagency Geothermal Coordinating Counc11.

8. Documentation of: $A-$ Assumptions, $M=$ Models, $(c)=$ complete, $(p)=$ partial, $(n)=$ none.

* Documentation In report in limited detall - details can be found in other documents

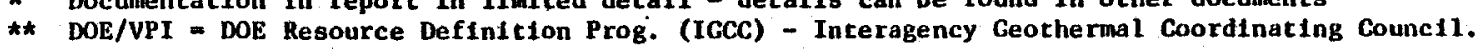




\section{TIE ROCKY MOUNTAIN PEGION PLANNING EFORT}

$3 B-23$ 

TITLE :

Regional Hydrothermal Commercialization Plan, Rocky Mountain Basin and Range Region, Chapter V, July 14, 1978.

STATES

INCLUDED: Utah, Idaho, Oregon

APPLICATIONS: Electric and Direct

PRINCIPAL

INVESTIGATOR: J.A. Close, EG\&G Idaho, Inc.

RESULTS: Strawman scenario were developed for two sites for electric generation, Cove Fort and Stillwater/Soda Lake, and for direct applications in the Vale-WeiserOntario area and on the Snake River Plain. Their main purpose was to illustrate for the state teams how scenario can be graphically depicted, but they also provide an aggressive but credible picture of how, when, and where hydrothermal energy might be utilized.

BENEFITS TO COMMERCIALIZATION:

The scenarios show how existing DOE initiatives can provide the seed for hydrothermal development.

See the following table for scenario evaluation. 


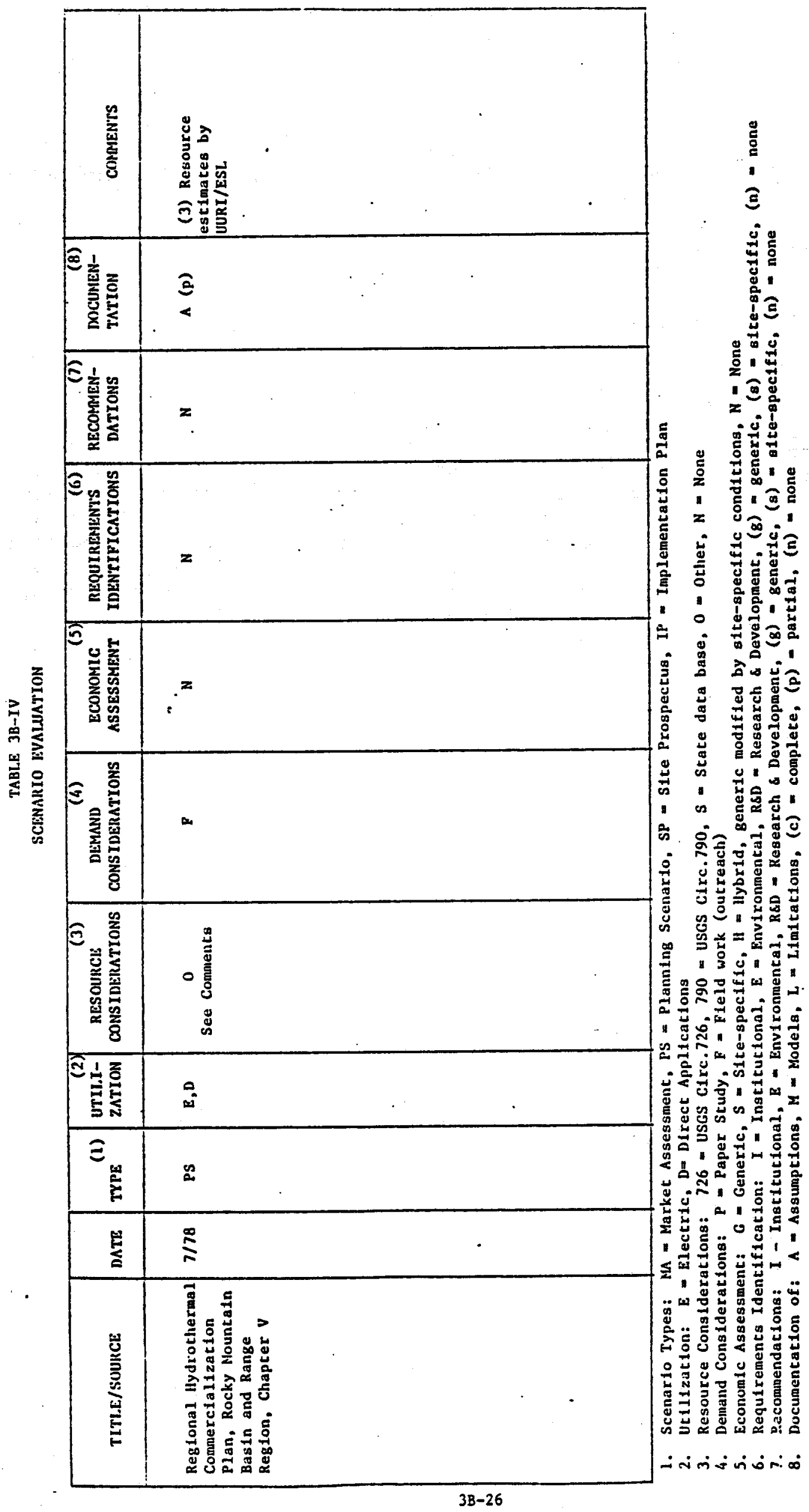


TITLE :

Regional Hydrothermal Market Penetration Analysis, Rocky Mountain Basin and Range Region. Draft, October 31, 1978. Appendices (Draft) updated January 23,1979.

STATES

INCLUDED:

New Mexico, Arizona, Nevada, Utah, Colorado, Wyoming, Idaho, Montana, North Dakota, South Dakota

APPLICATIONS: Electric and Direct Applications

PRINCIPAL

INVESTIGATOR: Joseph A. Hanny, EG\&G Idaho, Inc.

RESULTS :

This market assessment was a survey of potential applications of hydrothermal energy in the Rocky Mountains Basin and Range Region. The direct heat and electric applications are best described separately.

For direct heat use, which includes industrial applications to 4-digit SIC resolution and residential/commercial applications, resources in the $40^{\circ} \mathrm{C}$ to $275^{\circ} \mathrm{C}$ range were matched with existing (1975) demands on a county-by-county basis. Growth projections of demand were estimated and assumptions about market penetration, including retrofit, were made. Market penetrations for each SIC category and for residential/ commercial applications are given 163 of the 399 counties in the region for the years 1975, 1985, 2000, and 2020. Tables ranking the 40 counties with highest potential hydrothermal use and the top 20 hydrothermal process heat applications are presented.

Resources $>200^{\circ} \mathrm{C}$ were considered for electric applications before the year 2000 and resources $>150^{\circ} \mathrm{C}$ were consdiered thereafter. Based on resource and technology development assumptions in the report the DOE regional hydrothermal electric goals can be met.

BENEFIT TO COMERCIALIZATION:

The report identifies problem areas which will impede commercialization and lists factors that require consideration for DOE support to hasten accelerated resource development. The report also identifies and ranks the counties and industries in the region which have the greatest potential for utilizing the hydrothermal resource. 
TITLE: Summary Report: Southwest Regional Operations Research Program First Project Year, June 1977--August 1978, GP-01-79, December 1978.

STATES

INCLUDED: Arizona, Nevada, New Mexico, Colorado, Utah

APPLICATIONS: Electric and Direct Applications

PRINCIPAL

INVESTIGATORS: Joseph Marlin, New Mexico Energy Institute and State planning teams

AUTHORS: $\quad$ Richard T. Meyer, Ray Davidson, Western Energy Planners, Ltd.

RESULTS: $\quad$ Five different state planning teams were involved in developing the scenarios which vary significantly in approach and degree of detail, they are best summarized on a state-by-state basis.

The Colorado team found three locations within their state with temperatures suitable for electric power scenaration. Assuming a market exists estimates for developing the resources at these sites were made. For direct applications a matchup of market and resources was made for 27 municipalities plus a few other communities. A detailed scenario was developed for direct applications at Pagosa Springs. Major impediments are institutional. Continuation of this work is reported in Information Series 9.

The resource data needed to develop realistic scenarios was unavailable because it was proprietary or unknown. Scenarios for electric generation at 5 well known sites and for direct applications at several other sites were developed. Assumptions made on overcoming technical, institutional and economic barriers in a timely manner led to aggressive development scenarios.

BENEFITS TO COMMERCIALIZATION:

Generally, the scenarios give a better idea of how utilization of hydrothermal may develop in each state. The scenarios and other studies have resulted in identifying problem areas and listing recommendations, some for all 5 states and some for each state, to accelerate the development of the hydrothermal resource. 
NORTMEST REGION

PLANNING EFFORT

$3 B-29$ 
TITLE :

Detailed Development Scenario, Roosevelt Hot Springs Prospect, Utah, Draft January, 1979.

\section{STATES}

INCLUDED:

Utah

APPLICATION: Electric

PRINCIPAL INVESTIGATOR: Ward Wagstaff, Division of Water Rights, State of Utah

RESULTS: Reports the results of an implementation plan for the first electric generating plant of Roosevelt Hot Springs. It consists of a chart showing precedence relationships between activities required by federal, state and local governments and the private sector. Behind each activity on the chart is a paragraph number identifying where in the accompanying narrative background information and assumptions about the activity are found. All information is based on public records, federal regulatory requirements compiled by Ray LaSala, and interviews with involved federal, state and local officials and the developer.

CONTRIBUTION TO COMMERCIALIZATION:

This plan provides:

1. An identification of all federal, state and local permits required to bring a plant on line in Beaver County, Utah.

2. An accurate estimate of the time required to prepare and process each permit. This information along with that in Item 1 will be incorporated into the Utah Handbook of Institutional Procedures.

3. An identification of activities, interactions and negotiations in the private sector with actual experience and good estimates of their duration.

4. A plan against which progress can be measured. 
TITLE: Information Series 9, Geothermal Energy Development in Colorado: Processes, Promises and Problems, 1978.

STATES

INCLUDED: Colorado

APPLICATIONS: Electric and Direct Application

PRINCIPAL

INVESTIGATOR: Barbara Coe, Colorado Geological Survey, Department of Natural Resources, State of Colorado

RESULTS: Reports the results of site prospectus type scenarios developed for three sites for electric generation and 27 sites for direct applications. The sites for direct application were further categorized as:

- areas having some exploration or development activity

- areas having no activity but high potential

- areas having no activity but moderate potential

Estimates from the scenarios indicate that 16,000 homes plus commercial, industrial and public buildings, in 30 communities could be supplied with heat and hot water. Other direct applications include food processing, animal husbandry and timber drying.

Resource data were obtained from Colorado Geological Survey files. Potential markets were determined by field contact with local officials, Chambers of Commerce businessmen and other interested citizens, often in workshops. Data on state and federal permits requirements were obtained from interviews with officials in those offices. Significant impediments to commercialization were identified on a statewide basis.

BENEFITS TO COMMERCIALIZATION:

These scenarios have identified many new prospects in Colorado. The report has been widely circulated in the state and was often quoted in state newspapers. This has led to a significant increase in interest and inquiries about hydrothermal development. It has complemented and accelerated the outreach program.

See the following table for scenario evaluation. 
SCENARIO EVALUATION

\begin{tabular}{|c|c|c|c|c|c|c|c|c|c|c|}
\hline THLE/SUUKCE & DATE & TYPY $^{(1)}$ & $\begin{array}{l}\text { (2) } \\
\text { UTIJ.I- } \\
\text { ZATION }\end{array}$ & $\begin{array}{c}\text { RESOURCE } \\
\text { CONS IDERATIONS } \\
\text { (3) }\end{array}$ & $\begin{array}{c}\text { DEMAND } \\
\text { CONSIDERATIONS } \\
\text { (t) }\end{array}$ & $\begin{array}{c}\text { ECONOATC } \\
\text { ASSESSMIANT }\end{array}$ & $\begin{array}{c}\text { (6) } \\
\text { AEQUIREMENTS } \\
\text { IDENTIFICATIONS }\end{array}$ & $\begin{array}{l}\text { (7) } \\
\text { RECOANEN- } \\
\text { DATIONS }\end{array}$ & $\begin{array}{l}\text { (8) } \\
\text { DOCUNEN- } \\
\text { TATION }\end{array}$ & CORAMEITS \\
\hline $\begin{array}{l}\text { Detalled Development } \\
\text { Scenarfo Roosevelt } \\
\text { Hot Springs Prospect, } \\
\text { Utah/ DRAFT Uteh } \\
\text { Division of Water } \\
\text { Rights. } \\
\\
\text { Information Series } 9 \\
\text { Geothermal Energy } \\
\text { Development in Color- } \\
\text { ado; PROCESSES, } \\
\text { PRoIISES \& PROBLEMS/ } \\
\text { Colorado Geological } \\
\text { Survey }\end{array}$ & $1 / 79$ & IP & $\frac{\mathrm{e}}{\left(50 \mathrm{~kW}_{\mathrm{e}}\right)}$ & (See Comments) & $\mathbf{F}$ & (See Comments) & $\begin{array}{r}\text { I (S) } \\
\text { E (S) } \\
\text { R\&D (n) } \\
\\
\text { I (s) } \\
\text { E (g) } \\
\text { R\&D (n) } \\
\text { See Comments }\end{array}$ & (n) & $\hat{A}(p)$ & $\begin{array}{l}\text { (3) Flow testing of } \\
\text { exploracory wells } \\
\text { (5) Financial nega- } \\
\text { clons batween devel- } \\
\text { oper and market are } \\
\text { uni erway. } \\
\text { (8) No inodels used } \\
\text { (6) I and E are } \\
\text { gen:ric for state of } \\
\text { Colorado scenarios } \\
\text { assume current } \\
\text { technology is ade- } \\
\text { quate } \\
\text { (5) Competitiveness } \\
\text { with natural gas } \\
\text { assessed }\end{array}$ \\
\hline $\begin{array}{l}\text { RMBSR Regional Hydro- } \\
\text { thermal Market Pene- } \\
\text { tration Analysis, } \\
\text { DRAFT/ EG\&G, ESL }\end{array}$ & $1 / 79$ & MA & E,D & $\begin{array}{c}790,726 \\
\text { Sce Comments }\end{array}$ & $\begin{array}{l}\mathbf{P} \\
\ddots\end{array}$ & $\dot{N}$ & N & (i) & $A(c)$ & (8) no models used \\
\hline $\begin{array}{l}\text { Regional Hydrothermal } \\
\text { Commercialization } \\
\text { Plan, Rocky Mountain } \\
\text { Basin and Range } \\
\text { Region/DOF-DGE, DOE- } \\
\text { ID, EGSS, ESL. }\end{array}$ & $7 / 78$ & PS & E,D & $\begin{array}{c}\text { D. } \\
\text { See Comnents }\end{array}$ & $\mathbf{F}$ & $\mathbf{N}$ & $\mathbf{N}$ & (n) & $A(p)$ & $\begin{array}{l}\text { Resource data from } \\
\text { UURI/ESL. }\end{array}$ \\
\hline $\begin{array}{l}\text { 1. Scenario Types: } \\
\text { 2. Utilizacton: E } \\
\text { 3. Resource Consider } \\
\text { 4. Demand Considerat } \\
\text { 5. Economic Assessme } \\
\text { 5. Requlremients Ide } \\
\text { 7. Recommendations: } \\
\text { 8. Documentation of }\end{array}$ & $\begin{array}{l}\text { rations } \\
\text { tions: } \\
\text { ent: } 0 \\
\text { ntifick } \\
I=1\end{array}$ & $\begin{array}{l}726 \text { a } \\
\text { - Pape } \\
\text { Genert } \\
\text { on: G } \\
\text { titurio } \\
\text { gumpto }\end{array}$ & $\begin{array}{l}\text { SGS Circ } \\
\text { Study, } \\
\text { S }=\text { SI } \\
\text { Ceneric } \\
\text { a) } B= \\
M=M\end{array}$ & $\begin{array}{l}.726,790=\text { USC } \\
\text { p = Field Work } \\
\text { te-specif Ic, II } \\
\text { s = site spec } \\
\text { Environmental, } \\
\text { lodels, (c) - co }\end{array}$ & $\begin{array}{l}\text { reach) } \\
\text { prid, Gener1 } \\
n=\text { None } \\
\text { Research \& } \\
\text { (p) = pa }\end{array}$ & $\begin{array}{l}\text { te daca base, } \\
\text { odified by } 81 \\
\text { velopment, ( } \\
\text { al, }(n)=\text { non }\end{array}$ & $\begin{array}{l}=\text { Other, } N= \\
\text {-spectfic cond } \\
=\text { generic, (8) }\end{array}$ & $\begin{array}{l}\text { AAPG } f \\
\text { ons, } N=N \\
\text { site-spec1 }\end{array}$ & . & ne \\
\hline
\end{tabular}


TITLE :

STATES INCLUDED:

APPLICATIONS :

PRINCIPAL

INVESTIGATOR:

SUMMARY:

SIGNIFICANCE :
The district space heating potential of low temperature hydrothermal geothermal resources in the southwestern United States - NMEI - 10-1 Oct 78

Arizona, Nevada, New Mexico, Colorado, Utah

Direct

P.K. McDevitt, and C.R. Rao, New Mexico Energy Institute, New Mexico State University

The energy potential of 504 resource sites in the five State area are estimated at 0.0055 quads. The sites are then passed through two separate screening processes. First is that the resource temperature is between $65^{\circ}$ and $150^{\circ} \mathrm{C}$, and that it is within 50 miles of a market center with a population of over 1000 persons. This first screening reduced the 504 to 82 sites. The second screening is that the minimum acceptable rate of return is $12 \%$ greater. The second screening reduced the 82 sites surviving the first screening to 30 sites and 0.002 quads. The report documents the computer stimulation model (GIRORA - non-electric) used to calculate financial return on investment for space heating.

This effort is significant to resource applications providing a list of hydrothermal sites for the 5 state region which warrants the preparation of a site prospectus and marketing effort. 
TITLE :

Northwest Reglonal Research Planning (OR) Project (to be issued).

STATES INCLUDED: Alaska, Idaho, Montana, Oregon, Washington, Wyoming

APPLICATIONS: Electric and Direct Applications

PRINCIPAL

INVESTIGATOR: Robert P. Koeppen, Geo-Heat Ut1lization Center, Oregon Institute of Technology

RESULTS: A moderately to nearly complete data base has been established for each of 110 sites in the six-state region. Rough preliminary scenarios have been prepared for fifty-six sites, though all but a few sites lack even a brief technical review. Feasibllity analyses (conceptual design, retrofit analysis, and cost/benefit analysis) have been completed for only seven sites in the study area. The following table indicates the number of sites evaluated and progress on a state-by-state basis:

\begin{tabular}{lcccc} 
State & $\begin{array}{c}\text { Data } \\
\text { Texts }\end{array}$ & $\begin{array}{c}\text { Planning* } \\
\text { Scenarios }\end{array}$ & $\begin{array}{c}\text { Implementation } \\
\text { Plans }\end{array}$ & $\begin{array}{r}\text { Total } \\
\text { Scenar }\end{array}$ \\
\cline { 2 - 2 } & 14 & $(11)$ & 2 & 13 \\
Idaho & 38 & $2(7)$ & 4 & 13 \\
Montana & 14 & $(11)$ & 2 & 13 \\
Oregon & 19 & $2(11)$ & 1 & 14 \\
Washington & 14 & 7 & - & 7 \\
Wyoming & 11 & (4) & - & 4 \\
$\quad$ TOTAL & 110 & $11(44)$ & 9 & 64
\end{tabular}

* The numerals in parentheses indicate the number of planning scenarios which approach the detall of a site prospectus.

In addition to the detail work in these sites there now exist brief data bases (2-5 pages on each of eighty-two thermal springs in Alaska).

To facilitate data collection, as well as input from each state's appropriate agencles, the organizational structure for this task has included a geothermal specialist working out of the energy office of each state. This arrangement has proved exceedingly useful, providing on-site access of data for the project and a visible access point in each state for transferring information back to interested parties, both in the public and private sectors. 
BENEFITS TO COMERCIALIZATION:

One of the very significant impacts from this project, comes in the area of information transfer and liaison, a direct result of having a geothermal specialist stationed in each state's energy office. Most of the six states now have either newly-formed inter-agency geothermal development committees or at least interagency cooperation and dialogue, on geothermal matters, vastly improved over that of one year ago. Though many individuals in DOE and the various state's agencies share primary responsibility for this initiative, it is noteworthy that the instate-stationed specialists have served well and usefully as initial communication channels and liaison, drawing meetings of individuals otherwise not disposed to working together.

The site-by-site data base and scenarios will be of significant value to local, state, and federal planners in developing and modifying plans and strategies for geothermal commercialization. 
TABLE 3B-VI

SCENARIO EVALATION

\begin{tabular}{|c|c|c|c|c|c|c|c|c|c|c|}
\hline TITLE/SOURCE & DATE & TYPE & $\begin{array}{l}\text { (2) } \\
\text { UrILI- } \\
\text { zATION }\end{array}$ & $\begin{array}{l}\text { (3) } \\
\text { RESOURCE }^{\text {(3) }} \\
\text { CONS IDERATIONS }\end{array}$ & \begin{tabular}{|} 
DEMAND $^{(4)}$ \\
CONSIDERATIONS
\end{tabular} & $\begin{array}{l}\text { (5) } \\
\text { ECONOHIC } \\
\text { ASSESSMFNT }\end{array}$ & $\begin{array}{c}\text { (6) } \\
\text { REQUIREMENTS } \\
\text { IDENTIPICATIONS }\end{array}$ & $\begin{array}{l}\text { (7) } \\
\text { RECOMEN- } \\
\text { DATIONS }\end{array}$ & $\begin{array}{l}\text { (8) } \\
\text { DOCUMEN- } \\
\text { TATION }\end{array}$ & COMENTS \\
\hline $\begin{array}{l}\text { Oregon Insticute of } \\
\text { Teclinology (to be } \\
\text { released spring 79) } \\
\text { Alaska. } \\
\text { Kotzebue } \\
\text { Klawasi } \\
\text { Capital (Willow) } \\
\text { Unalaska } \\
\text { Tenakee } \\
\text { Bell Isle } \\
\text { Unnak } \\
\text { Manley } \\
\text { Clear Creek H.S. } \\
\text { Baranof } \\
\text { Adak } \\
\text { Chena } \\
\text { Pilgrim H.S. } \\
\text { Idalio } \\
\text { Yellowstone/Island } \\
\text { Park } \\
\text { Vulean } \\
\text { Raft Rtver } \\
\text { Conda } \\
\text { Bruneau } \\
\text { Crane Creek } \\
\text { Castle Creek }\end{array}$ & 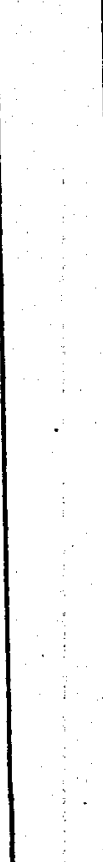 & $\begin{array}{l}\mid \\
\begin{array}{l}\text { IP } \\
\text { PS } \\
\text { IP }\end{array} \\
\text { PS } \\
\text { PS } \\
\text { IP } \\
\text { PS }^{+} \\
\mid\end{array}$ & $\begin{array}{l}15 \mathrm{D} \\
10 \mathrm{E}\end{array}$ & $\begin{array}{r}726+0 \\
726+s \\
\end{array}$ & \begin{tabular}{|} 
P with minor $\mathbf{F}$ \\
\\
$\mathbf{P}+\mathbf{F}$
\end{tabular} & $\mathbf{c}+\mathbf{s}$ & $\begin{array}{r}I(g) \\
E(g) \\
R \& D(g) \\
\\
\\
\\
I(g) \\
E(g) \\
R \& D(g)\end{array}$ & $\begin{array}{r}I(g) \\
E(g) \\
R S D(g) \\
\\
\\
\\
I(g) \\
E(g) \\
R \& D(g)\end{array}$ & $\begin{array}{l}\mathbf{A}(\mathbf{c}) \\
\mathbf{M ( c )}\end{array}$ & $\begin{array}{l}\text { +Strawman - narrative } \\
\text { Scenarto intended } \\
\text { to Inform and elicit } \\
\text { response }\end{array}$ \\
\hline
\end{tabular}

1. Scenario Types: MA = Market Assessment, PS= Planning Scenarlo, PS ${ }^{+}=$Plaining Scenario with field work and detall approaching a site prospectus, SP = Site Prospectus, IP = Implementation Plan

2. Utilization: $\mathrm{E}=$ Electric, $\mathrm{D}$ - Direct Appl1cations

4. Demand Considerations: $P=$ Paper study, $F=$ Field work (outreach)

-

列

6. Requirements Identification: I = Institutional, $E=$ Environmental, Rod - Research Development, (g) (s) generic, site-specific, (n) $=$ none.

7. Recommendations: $I=$ Insti tutional, $E=$ environmental, R\&D $=$ Research \& Development, (g) 
TABLE 3B-VI CONT'D

SCENARIO EVALWATION

\begin{tabular}{|c|c|c|c|c|c|c|c|c|c|c|}
\hline TITLE/SOURCE & DATE & TYPE $^{(1)}$ & $\begin{array}{l}\text { (2) } \\
\text { UTILI- } \\
\text { 2ATION }\end{array}$ & $\begin{array}{c}\text { RESOURCE } \\
\text { CONS IDERATIONS }\end{array}$ & $\begin{array}{c}\text { DEMAND } \\
\text { CONS IDERATIONS }\end{array}$ & $\begin{array}{l}\text { ECONOMIC } \\
\text { ASSESSMFNT }\end{array}$ & $\begin{array}{l}\text { (6) } \\
\text { REQUIREMENTS } \\
\text { IDENTIFICATIONS }\end{array}$ & $\begin{array}{l}\text { (7) } \\
\text { RECOMMEN- } \\
\text { DATIONS }\end{array}$ & $\begin{array}{l}\text { (8) } \\
\text { DOCUMEN- } \\
\text { TATION }\end{array}$ & COMMENTS \\
\hline $\begin{array}{l}\text { Idaho Cont'd) } \\
\text { Mountain Home } \\
\text { Magic H.S. } \\
\text { South Central Idaho } \\
\text { (Twin Falls, Burley } \\
\text { Hailey) } \\
\text { Madison Co. (Rexberg) } \\
\text { Ada Co. (Boise) } \\
\text { Washington Co. (Wei- } \\
\text { ser) } \\
\text { Monzana. } \\
\text { Ennls } \\
\text { White Sulphur Spring } \\
\text { Warin Springs } \\
\text { West Yellowstone } \\
\text { New Biltnore H.S. } \\
\text { Marysville } \\
\text { Broadwater } \\
\text { Hunter H.S. } \\
\text { Deer Lodge } \\
\text { Corwin Sp. } \\
\text { Bozeman H.S. } \\
\text { Boulder H.S. } \\
\text { Barkells H.S. }\end{array}$ & & $\begin{array}{c}\mathrm{IP}_{\mathrm{PS}^{+}} \\
\text {SP-IP } \\
\\
\mathrm{PS}^{+} \\
\mathrm{IP}^{+} \\
\mathrm{PS}^{+} \\
\\
\mathrm{PS}^{+} \\
\mathrm{IP}^{+} \\
\mathbf{P S}^{+} \\
\end{array}$ & $\begin{array}{r}13 D \\
5 E\end{array}$ & $726+s$ & $P \& F$ & G(Incomplete) & $\begin{array}{r}I(g) \\
E(g) \\
R \& D(B)\end{array}$ & $\begin{array}{r}I(g) \\
E(g) \\
R S D(s)\end{array}$ & $\begin{array}{l}A(c) \\
M(c)\end{array}$ & $\begin{array}{l}{ }^{+} \text {Strawman - narrative } \\
\text { intended to inform } \\
\text { and ellcit response }\end{array}$ \\
\hline
\end{tabular}

1. Scenarto Types: $M A=$ Market Assessment, $P S=$ Planning Scenarto, PS ${ }^{t}=$ Planniug Scenarlo with fleld work and detail approaching a site prospectug, $\mathrm{SP}=$ S1 te Prospectus, IP = Implementation Plan

2. Utilization: $E=$ Electric, $D=$ Direct Applications

3. Resource Considerattons: $726=$ USGS Circ.726, $790=$ USGS C1rc.790, $s=$ state data base, $o=0$ other, $n=$ none.

4. Demand Considerations: $P$ = Paper Study, $F=$ Field work (Outreach)

5. Econonic Assessment: $G=$ Generic, $S=$ Site-specific, $H=$ Hybrid, generic modified by site-spectfic conditions, $N=$ None.

6. Ruquite

7. Recommendations; $I=$ Institutional, $E=$ Environmental, R\&D = Research Development, $(g)=$ generic, (s) $=$ site-specific, (n) none.

7. Recounencacton of a $A$ = Aseut 
TABLE 3B-VI CONT'D

SCENARIO EVALATION

\begin{tabular}{|c|c|c|c|c|c|c|c|c|c|c|}
\hline TITLE/SOURCE & DATE & $\operatorname{TYPE}^{(1)}$ & $\begin{array}{r}\text { (2) } \\
\text { UTILI- } \\
\text { 2ATION }\end{array}$ & $\begin{array}{c}\text { RESOURCE }^{(3)} \\
\text { CONSIDERATIONS }\end{array}$ & $\begin{array}{c}\text { DEMAND } \\
\text { CONSIDERATIONS }\end{array}$ & $\begin{array}{c}\text { ECONOMIC } \\
\text { ASSESSMRNT }\end{array}$ & $\begin{array}{l}\text { (6) } \\
\text { REQUIREMENTS } \\
\text { IDENTIPICATIONS }\end{array}$ & $\begin{array}{l}\text { (7) } \\
\text { RECOMMEN- } \\
\text { DATIONS }\end{array}$ & $\begin{array}{l}\text { (B) } \\
\text { DOCUMEN- } \\
\text { TATION }\end{array}$ & COMMENTS \\
\hline $\begin{array}{l}\text { Oregon } \\
\text { Mr. Hood } \\
\text { Carey H.S. } \\
\text { Brteten Bush H.S. } \\
\text { Belknap - Foley } \\
\text { McCredie H.S. } \\
\text { Newbury Caldera } \\
\text { Burns Butte } \\
\text { Kalamath Falls } \\
\text { Lakeview } \\
\text { Summer Lake } \\
\text { Alvord Valley } \\
\text { Vale } \\
\text { LeGrande } \\
\text { Crump Sp. }\end{array}$ & & $\mathrm{PS}^{+}$ & $\begin{array}{r}15 \mathrm{D} \\
2 \mathrm{E}\end{array}$ & $726+s+0$ & $\mathbf{P}+\mathbf{F}$ & $3 \mathrm{~S}$ & $\begin{array}{r}I(g) \\
\mathbf{E}(g) \\
\operatorname{RSD}(\mathbf{s})\end{array}$ & $\begin{array}{r}I(g) \\
R(g) \\
R \& D(s)\end{array}$ & $\begin{array}{l}A(c) \\
M(c)\end{array}$ & $\begin{array}{l}\text { +Strawnan - narrative } \\
\text { Scenario intended } \\
\text { to inform and elfcit } \\
\text { response }\end{array}$ \\
\hline $\begin{array}{l}\text { Washington } \\
\text { Baker H.S. } \\
\text { Mt. Rainier } \\
\text { Mt. Adams } \\
\text { Mt. St. Helans } \\
\text { Indian Heaven } \\
\text { Yak1na } \\
\text { Olympic Sol Due } \\
\text { (Nat'1 Park) }\end{array}$ & & Ps $^{+}$ & 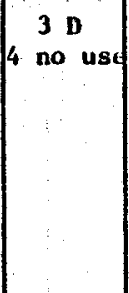 & $726+s+0$ & $\mathbf{P}+\mathbf{r}$ & is & $\begin{array}{r}I(g) \\
E(g) \\
R \& D(s)\end{array}$ & $\begin{array}{r}I(g) \\
E(g) \\
R \& D(s)\end{array}$ & $\begin{array}{l}A(c) \\
H(c)\end{array}$ & \\
\hline
\end{tabular}

1. Scenario Types: MA = Market Assessment, PS = Planning Scenario, PS ${ }^{+}=$Plianning Scenario with field work and detail approaching a site prospectus, SP $=$ Site Prospectus, IP = Implementation Plan

2. Utilization: $E=$ Electric, $D=$ Di rect Applications

3. Resource Considerations: $726=$ USCS C1rc.726, $790=$ uSGS C1rc.790, S = State data base, $0=$ other, $n=$ none.

4. Demand Considerations: $P=$ Paper Study, $F=$ Field work (Outreach)

5. Economic Assessment: $G=$ Ceneric, $S$ - Site-specific, $H=$ Hybrid, generic modified by site-specific conditions, $N=$ None

6. Requi rements Identification: I = Institutional, $E=$ Envi ronmental, RED = Research \& Development, (g) $=$ generic, (S) $=$ sIte-specific, (n) $=$ none.

7. Recomendactong: $I$ Institutional $E=$ Envirose

8. Documentation of: $A=$ Assunptions, $M=\operatorname{Model},(c)=$ complete, $(p)=$ partial, $(n)=$ nune. 
TABLE 3B-VI CONT'D

SCENARTO EVALUATION

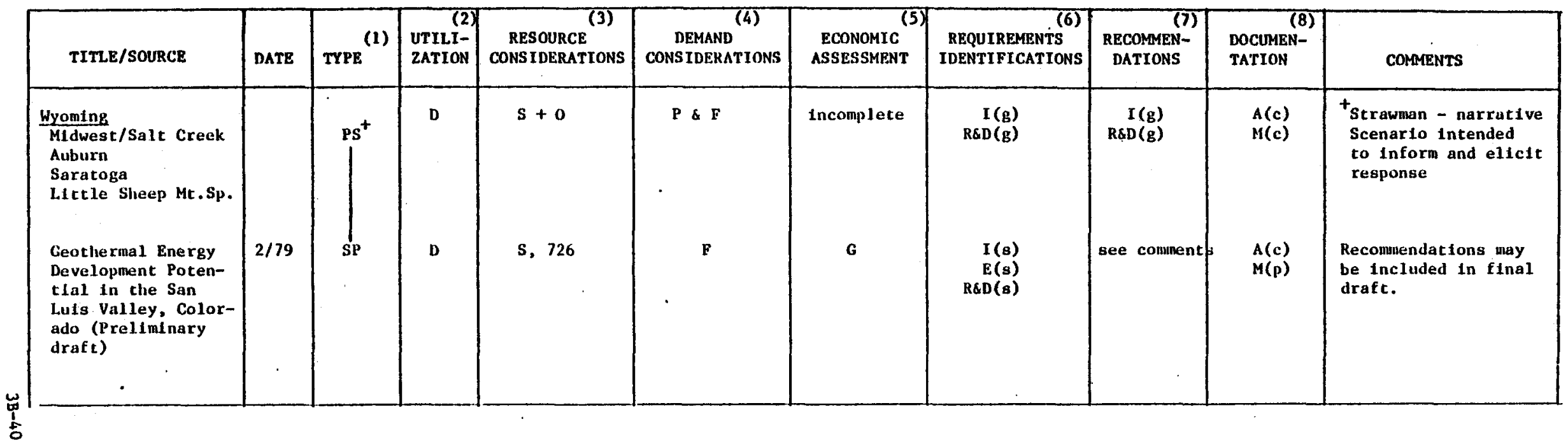

1. Srenario Types: MA = Market Assessment, PS = Planning Scenario, PS ${ }^{+}$Planning Scenario w1th field work and detall approaching a site prospectus, SP = Site Prospectus, IP = Implementation Plan

2. Utilization: $\mathrm{E}=$ Electric, $\mathrm{D}=$ Direct Application

3. Resource Considerations: $726=$ USGS C1rc.726, $790=$ uSGS C1rc.790, $s=$ State data base, o other, $n=$ none.

4. Deinand Considerations: $P$ - Paper Study, F = Field work (outreach)

5. Economic Assessment: $G$ = Generic, $S=$ site-specific, $H=$ Hybrid, generic modified by site-specific conditions, $n=$ none.

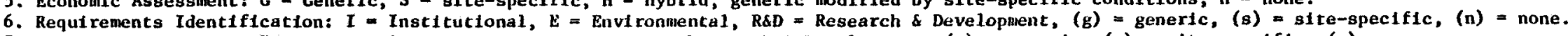

7. Recomnendations: $I$ = Institutional, $E=$ Environmental, R\&D = Research \& Development, $(g)=$ generic, (s) $=$ site-specific, (n) = none.

8. Documentation of: $A=$ Assumptions, $M=$ Models, $(c)=$ complete, $(p)=$ partial, $(n)=$ none. 
PACIFIC REGION

PLANNING EFFRT

$3 B-41$ 

TITLE :

Pacific Region Federal Geothermal Commercialization Plan (Working Draft Dated 16 October 1978)

STATES

INCLUDED:

Alaska, Washington, Oregon, California, Hawaii

APPLICATIONS: Electric, Direct and Integrated

AUTHORS: San Francisco Operations Office, U.S. Department of Energy

ABSTRACT: This is a highly readable and informative status report, prospect data file and program plan which emphasizes an early commercialization of both electric- and direct-use-oriented resources. Only two scenarios, or site development plans are presented: electric plants for Heber, CA (no identification of the utilities or the conversion processes), and integrated electric and sugar refining for Puna, HI. Succinct summary status reports and summary resource descriptions (especially geologic settings) are presented for each state. Similarly, energy supply and demand data are summarized for the region. The relationship of the region to each of the federal program areas and initiatives (R\&D areas, incentives, barrier definition and mitigation, etc.) is also established. New goals for direct and electric applications are presented.

APPLICABILITY:

An updated state-level information base. A good source document for commencing site prospectuses. A regional management and program structure for commercialization is presented.

See the following table for scenario evaluation. 
TABLE 3B-VII

SCÉNARIO BVALUATION

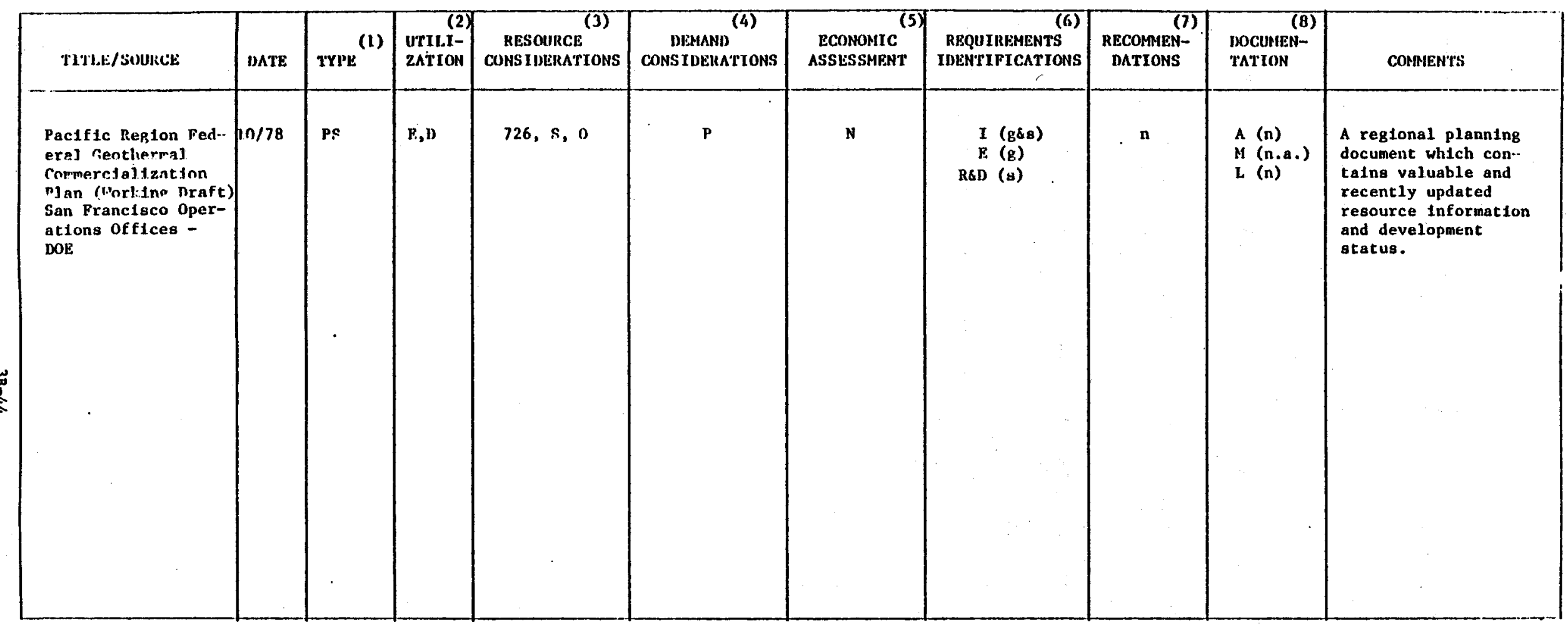

1. Scenarto Types: $M A=$ Market Assessment, PS = Planning Scenar1o, SP = S1te Prospectus, IP = Implementation P1an

2. Nttjtzation: $\mathrm{F}$ - Flectric, $\mathrm{D}=$ Direct Applications

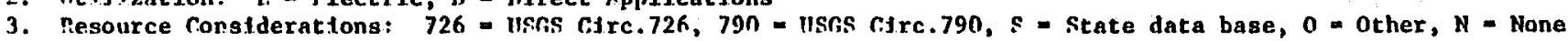

$\therefore$ nemand Constderations: $p$ - Paper Study, $F=$ Field work (outreach)

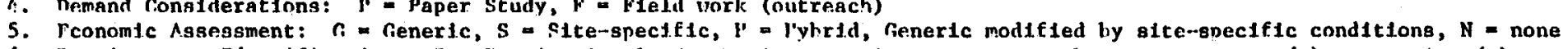

6. Penulrementa Identification: I - Instititional, $\mathrm{F}$ - Fnvironmental, R\&D = Pesearch \& Development, (g) = generic, (s) = site-specific, (n) - none

7. Recommendations: $T=$ Ingtitut Innal, $F=$ Invironmental, p\&I = Research \& Development, (R) = generic, (s) = slte-specific, (n) - none

B. Documentation of: $A=$ Assumptions, $M=$ Models, $I=1.1 m 1$ tations, $(c)=$ comnlete, (p) $=$ partial, (n) $=$ none 
TITLE: Analysis of Requirements for Accelerating the Development of Geothermal Energy Resources in California (Nov. 1977)

AUTHOR: C.D. Fredrickson, Jet Propulsion Laboratory

STATE/UTILIZATION :

California/Electric

SUBJECT: $\quad$ Presents 13 Site Specific scenarios for geothermal development and actions necessary to achieve.

RESULTS: $\quad$ 1. Identified status of resource knowledge and deve1opment in this state.

2. Identified leasing, permitting, drilling and plant committment schedules to realize the scenarios.

3. Identified key types of actions critical to rea1ize scenarios based on analysis of current status, economics, and postulated schedule.

4. Developed site development activity model for lst plant of federal and private lands.

5. Developed 200 MW site development model to quantify land use/leasing requirements.

See the following table for scenario evaluation. 
TABLE 3B-VIII

SCENARIO EVALUATION

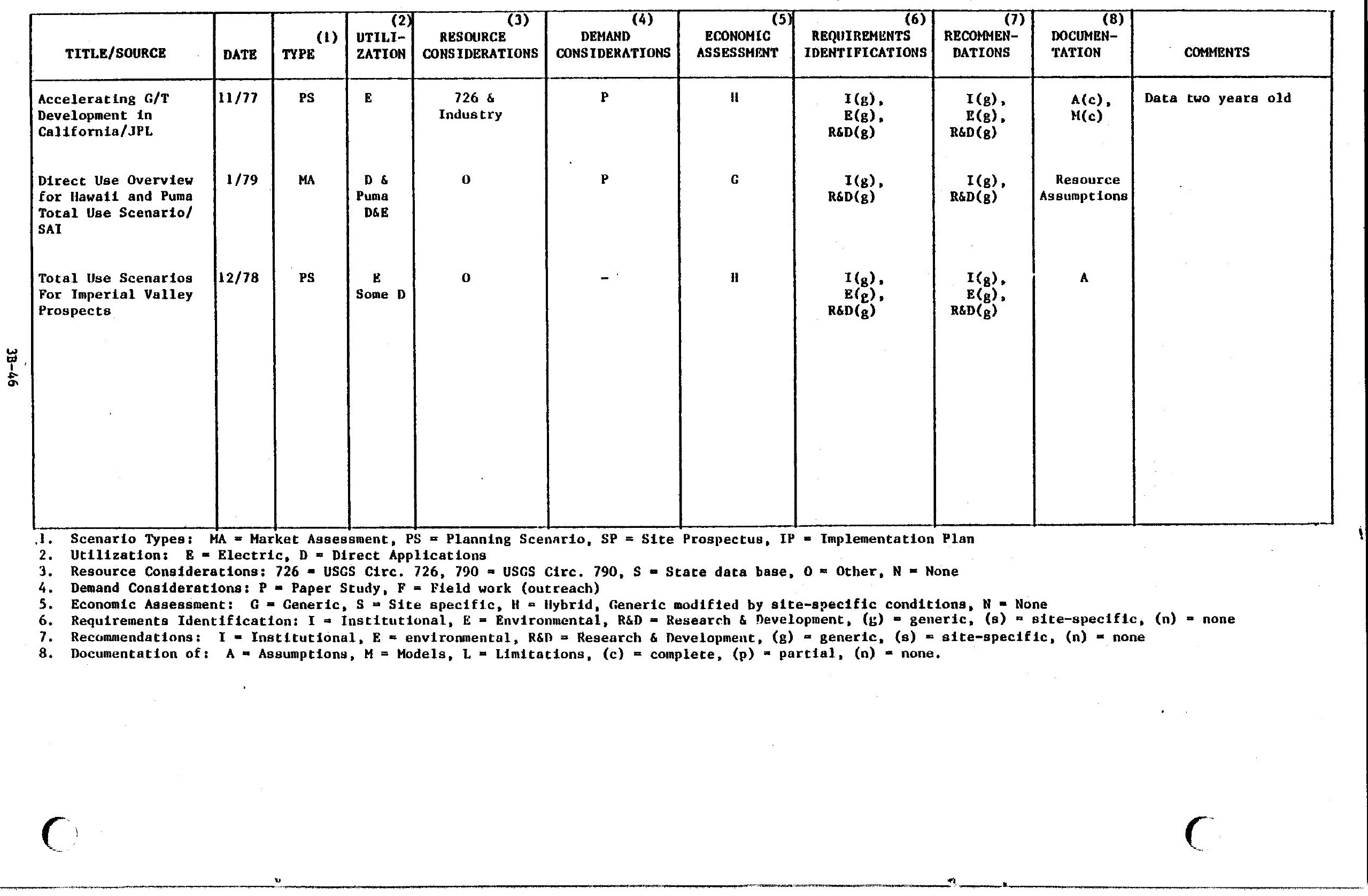


TITLE: Direct use overview for Hawaii and total use scenario for Puna (HI) Jan 1979

AUTHOR: $\quad$ Science Applications, Inc.

STATE/UTIL IZATION :

Hawaii/Direct and Puna/Total Use

SUBJECT: Fourteen moderate and high temperature geothermal prospects were identified and direct uses assessed. An integrated (electric and direct use) scenario was presented for Puna.

RESULTS: $\quad$ 1. Identified 14 geothermal prospects in the state and supporting data.

2. Presented discussion of potential markets.

3. Presented integrated scenario for Puna as resource is potentially much larger than current local demands.

4. Stated need for more detailed studies.

See the following table for scenario evaluation. 
TABLE 3B-IX

SCEnario EVALUATION

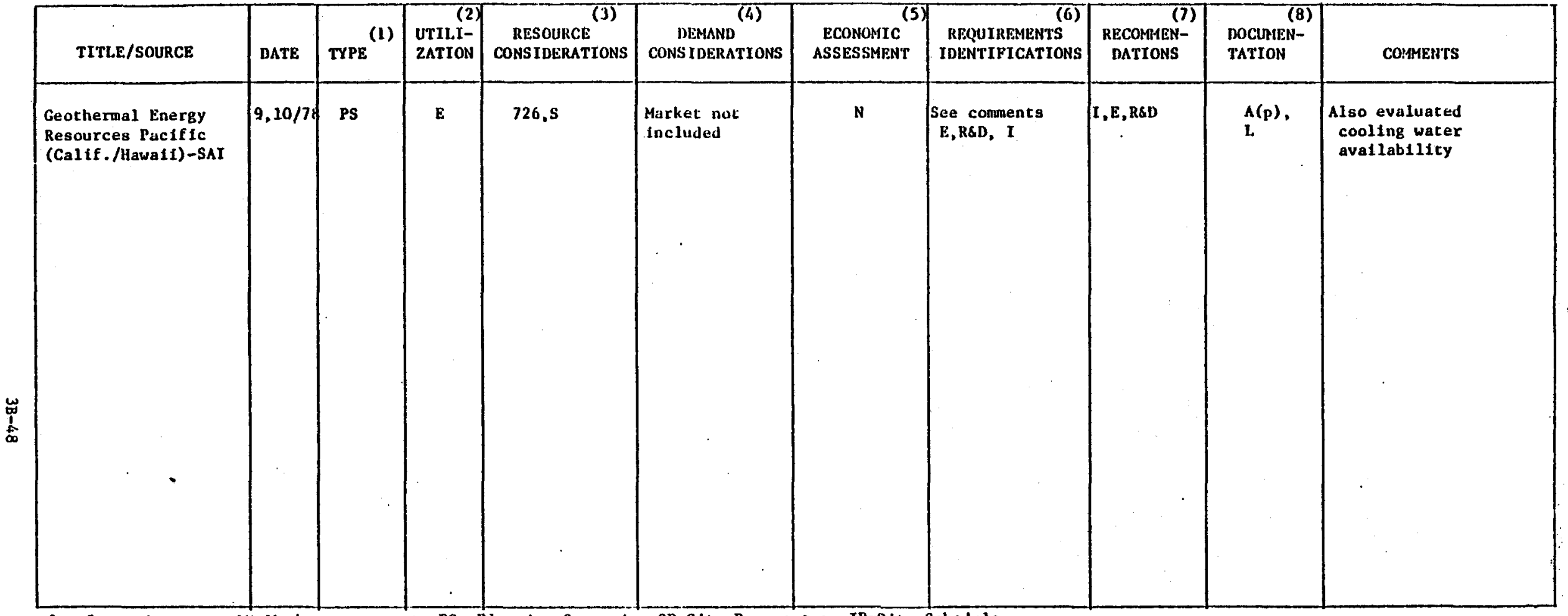

1. Scenario types: MA=Market ssessment, $P S=$ Plamning Scenario, SP=Stre Prospectus, IP=Site Schedule

2. Utilization: E- Electric, D-Direct Applications

3. Resource Constderations: 726=USGS Cfrc. 726, 790=USGS Circ. 790, S=State dara base, $0=0$ cher, N=None

4. Demand Considerations: P=Paper study, F=Field work (outreach)

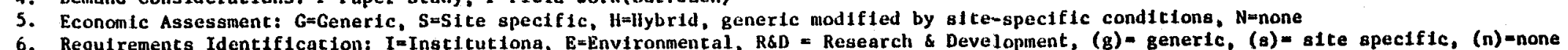

7. Reconmendat Ions: I-Institutional, E=Environmental, RSD - Researchment \& Development, (g) = generic, (s)=site spectfic, (n)-none

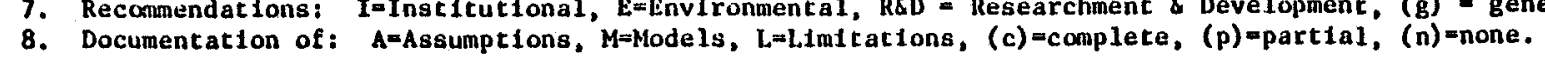


TITLE: Total use scenario for Imperial Valley prospects (Dec. 1978)

AUTHOR: $\quad$ Science Applications

STATE/UTILIZATION :

California's Imperial Valley, primarily electric.

SUBJECT: $\quad$ Presents development status and development prospects for Imperial Counties 6 KRGA's. Emphasis is on electric utilization but direct applications of beet pulp drying (Holly sugar) and space conditioning city of E1 Centro discussed.

RESULTS: $\quad$ 1. Presents background, resource development status and plans leading to scenarios for $1000 \mathrm{MW}$ on line in Imperial County by 1986 and 4500 MW FY 2020.

2. Identifies need for cooling water study.

3. Presents economic, technical and institutional/ regular.

4. Present progress monitor approach. 
TITLE: Regional Systems Development for Geothermal Energy Resources Pacific Region (California and Hawaii)

REPORT NO.: Status reports No. 6 and 7 , Sept. and Oct. 1978.

Systems Development Corporation - TM(L) 6060/001/06\& 07

PRINCIPAL

INVESTIGATOR: Victor G. Olcotta - SDC

ELECTRIC OR

NON-ELECTRIC :

Primarily electric

ABSTRACT: The reports document work on their main tasks as follows:

1. Develop implementation plans. Draft plans are shown for the following sides for electric power generation.

\section{a. California}

Imperial County's KRGA's

Coso Hot Springs

Mono-Long Valley

Wende1-Amedee

b. Hawaii

Puna geothermal area

2. Regional project monitoring and progress evaluation.

Workbooks have been completed for the Geysers Steam area and Surprise Valley.

Visits and data collection are used.

3. Make resources evaluation.

Mini-topical reports requirements and availability of water in Imperial and Coso Hot Springs for electric generation cooling requirements are summarized. 
SIGNIFICANCE: The reports up date previous resource estimates and provide power-on-line estimates for electrical production for all of the currently considered geothermal resources capable of electrical production. These estimates are not constrained or 1 imited by market considerations and are therefore of 1 imited significance, except in the case of Imperial Valley, where the limit of power production is set by allocation of Imperial Irrigation District set aside of water required for cooling.

See the following table for scenario evaluation. 
TABI.E 3B-X

SCENARTO EVALUATION

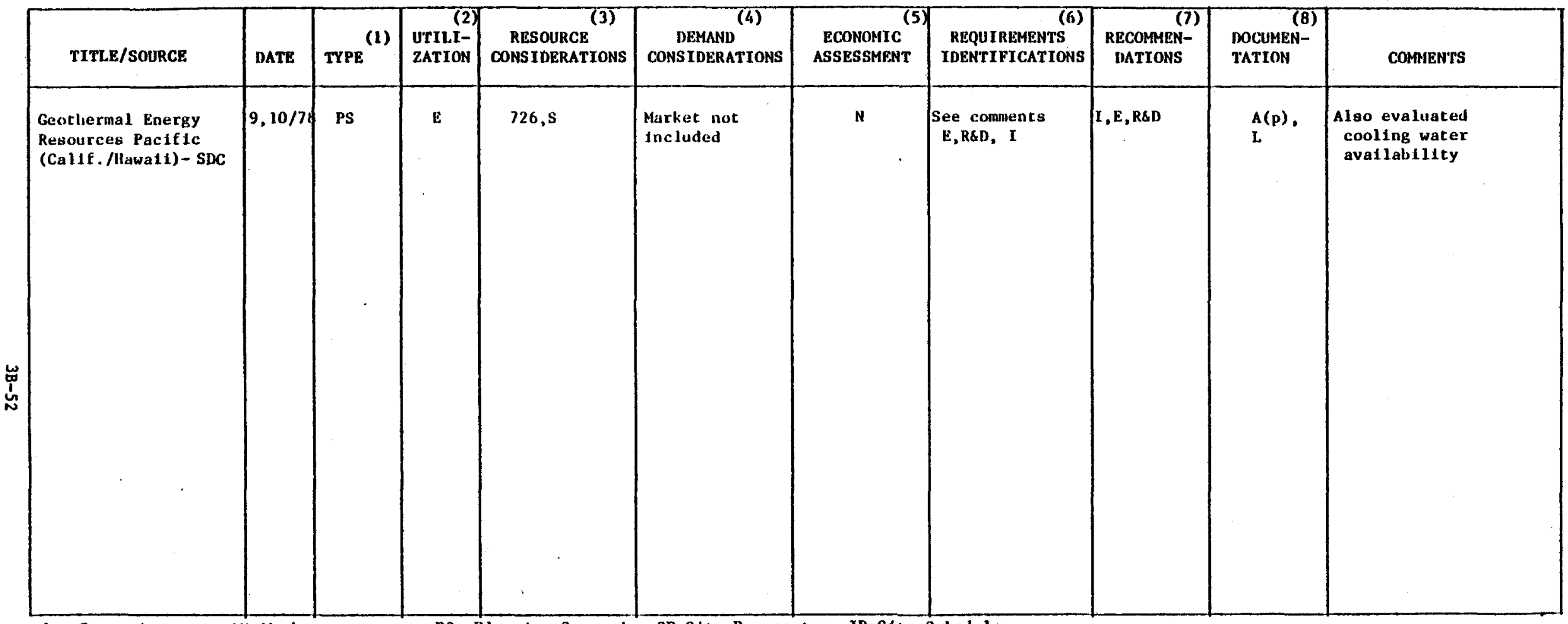

1. Scenario types; MA=Market ssessment, $P S=P$ lanning Scenario, $S P=S i t e$ Prospectus, IP=Site Schedule

2. Utilization: Em Electric, D-Direct Applications

3. Resource Constderations: 726 $=$ USGS CIrc. 726, 790=USGS Circ. 790, S=State data base, $0=0$ other, N=None

4. Demand Considerations: $P=P$ aper study, F=Field work (out reacli)

5. Economic Assessment: $G=G e n e r i c, S=S i t e$ specific, H=Hybrid, generic modified by site-spectfic conditions, $N=n o n e$

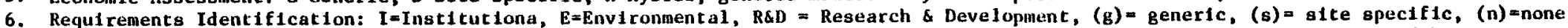

7. Recomendations: I=Institutional, Estivi ronmental, R\&D = Researchment \& Development, (g) generic, (s)=site specific, (n)=none

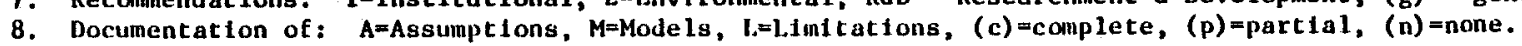


TITLE : A Technology Assessment of Geothermal Energy Resource Development

APPLICABLE

AREAS :

Covers the U.S., generically, for Electricity Development

APPLICATION: Electric, mainly, source consideration of direct applications.

PRINCIPAL

INVESTIGATOR: The Futures Group with Bechtel as a subcontractor.

RESULTS: This is an early document in the field. The Technological Assessment was done for NSF. A general market assessment at a national and generic level is part of the technology assessment. Public interest groups are identified. Institutional impacts are anticipated. Because of its comprehensive nature, it is a useful source document for newcomers.

IMPACT ON COMMERCIALIZATION :

An early document in raising national consciousness to the potentials of geothermal development. Most information has been superseded by more recent studies.

See the following table for scenario evaluation. 
TABLE 3B-XI

SCENARIO EVALUATION

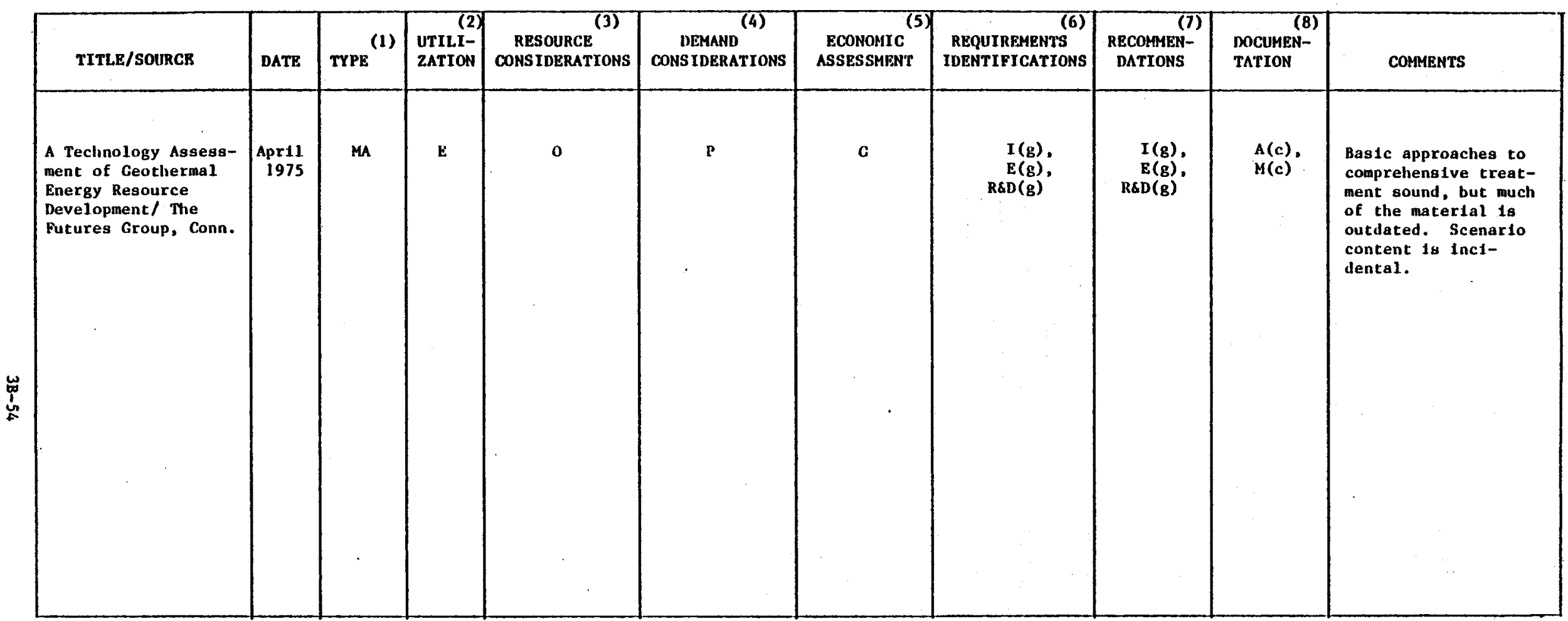

1. Scenarlo Types: MA = Market Assessment, PS = Planning Scenario, SP = Site Prospectus, IP = Implementation Plan.

2. Utllization: $E=$ Electric, $D=$ Direct Applications

3. Resource Considerations: $726=$ USGS Circ.726,790 = usGs circ.790, $S=$ state data bage, $0=0$ other, $N=$ None

4. Demand Considerations: $P=$ Paper Study, F $=$ Fledl work (outreach)

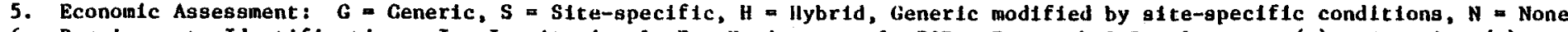

6. Requirements Identification: I = Institutional, E = Environmental, R\&D = Research \& Development, (g) = generic, (s) = s1te-specific, (n) = none

7. Recommendations: I = Institurtonal, $B=$ Environmental, R\&D = Research \& Development, (g) = generic, (s) = site-spectfic, (n) = none,

8. Documentation of: $A=$ Assumpt Lons, $M=$ Models, $L=$ Limitations, $(c)=\operatorname{complete,~}(p)=$ partial, $(n)=$ none 
TITLE: Analysis of Geothermal Energy Development Scenarios (1976)

OBJECTIVE: Determine likely feasible geothermal development (in a macro sense).

APPLICATIONS: Electric

PRINCIPAL

INVESTIGATOR: R. Trehan, MITRE/Metrek

RESULTS: $\quad$ o Geothermal not competitive economically without significant cost reductions.

- Likely long-term growth rate $\leq 15 \%$ P.A. because of constraints on market penetration, resource lifetime, land leasing, drill rigs.

- Likely short-term development $\leq 4800$ MWE by 1985.

RELEVANCE TO COMMERCIALIZATION:

Provided basis for later studies.

- Effective budget range is $(2.8-6)$ million dollars per year for five years.

RELEVANCE TO COMMERCIALIZATION EFFORT:

- Indicated industry perceived effectiveness and need for improvement on current Geothermal Exploration and Resource and Reservoir Assessment (GERRA) R\&D program to facilitate early commercialization of hydrothermal resource.

See the following table for scenario evaluation. 
TABLE 3B-XII

SCENARIO EVALIATION

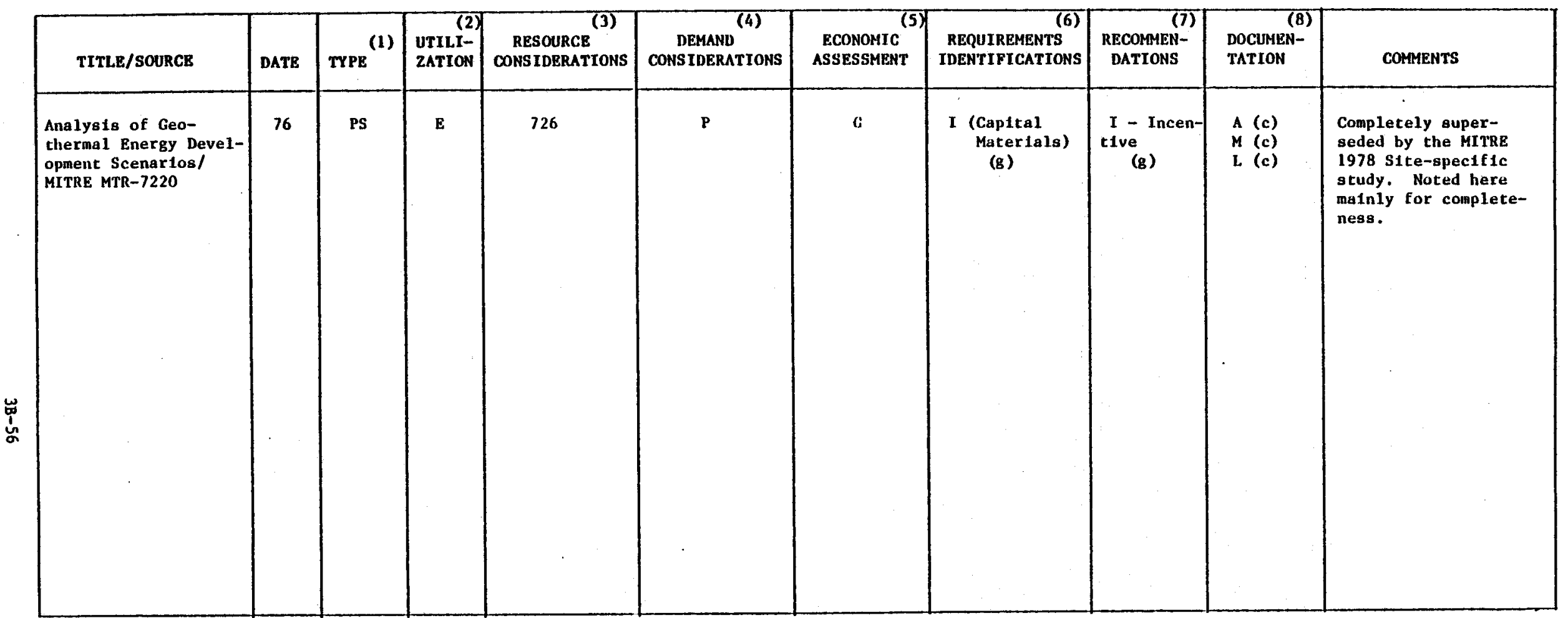

1. Scenario Types: MA = Market Assessment, PS = Planning Scenario, SP a Site Prospectus, IP = Implementation Plan

2. Utilization: $\mathrm{E}$ = Blectric, $\mathrm{D}=$ Direct Applications

3. Resource Considerations: 726 = USGS Circ. $726,790=$ USGS Circ. $790, S=$ State data base, $0=0$ other, $N=$ None

4. Demand Considerations: $P=$ Paper Study, $F=$ Field Work (outreach)

5. Economic Assessment: $G=$ Generic, $S=S$ Ste-specific, $\|=$ Hybrid, Generic modif ted by site-specific conditions, $N=$ None

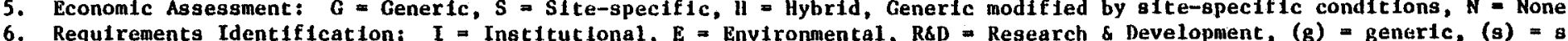

6. Requirements Identifcation, Institutional, $E$ - Environmental, R\&D = Research \& Development, (g) $=$ generic, (s) $=$ site-specific, (n) = none

7. Recommendations: $I=$ Institutional, $E=$ Environmental, R\&D = Research \& Development, (g) $=$ genertc, (s) $=$ site-specific, ( $n$ ) $=$ none

8. Documentation of : $A=$ Assumptions, $M=$ Models, $L=$ Limitations, $(c)=$ complete, $(p)=$ partial, (n) $=$ none 
TITLE: Site-Specific Analys is of Geothermal Development (1978)

OBJECTIVE: To examine economic competitiveness of sites postulated for early development by DGE

\section{APPLICATIONS: Electric}

PRINCIPAL

INVESTIGATOR: H. Dhillon, MITRE/Metrek

RESULTS: Both R\&D program to reduce costs and fiscal incentives are needed to make geothermal economically competitive at majority of sites studied, thereby achieving one necessary condition for development.

RELEVANCE TO COMMERCIALIZATION:

Provides support for broad-based program. Indicates sites which may be competitive already, sites which may be made competitive by present policies and sites which may still be too expensive.

Report includes detailed site-specific data base.

See the following table for scenario evaluation. 
TABLE $3 B-X I I I$

SCENARTO EVALUATION

\begin{tabular}{|c|c|c|c|c|c|c|c|c|c|c|}
\hline TITLE/SOURCE & DATE & TYPE $^{\text {(1) }}$ & $\begin{array}{l}\text { (2) } \\
\text { UTILI- } \\
\text { ZATION }\end{array}$ & \begin{tabular}{|c|} 
RESOURCE $^{\text {(3) }}$ \\
CONSIDERATIONS
\end{tabular} & $\begin{array}{c}\text { DEMAND }^{(4)} \\
\text { CONS IDERATIONS }\end{array}$ & $\begin{array}{l}\text { ECONOMIC } \\
\text { ASSESSMENT }\end{array}$ & $\begin{array}{l}\text { (6) } \\
\text { REQUIREMENTS } \\
\text { IDENTIFICATIONS }\end{array}$ & $\begin{array}{l}\text { (7) } \\
\text { RECOMMIEN- } \\
\text { DATIONS }\end{array}$ & $\begin{array}{l}\text { (8) } \\
\text { DOCUMEN- } \\
\text { TẠTION }\end{array}$ & COMMENTS \\
\hline $\begin{array}{l}\text { Site Specific Anal- } \\
\text { ysis of Geothermal } \\
\text { Development }\end{array}$ & & & & & & & & & & $\cdot$ \\
\hline $\begin{array}{l}\text { MITRE } \\
\text { MTR- } \\
7586\end{array}\left\{\begin{array}{l}\text { VIII-Data Files } \\
\text { VII-Scenarios } \\
\text { \& Requirements } \\
\text { VI-Sumnary } \\
\text { Report }\end{array}\right.$ & 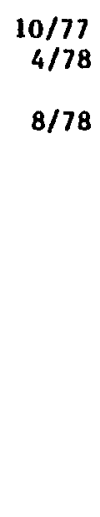 & $\begin{array}{c}\text { PS/SP } \\
\text { PS } \\
\text { PS }\end{array}$ & $\begin{array}{l}\mathbf{E} \\
\mathbf{E} \\
\mathbf{E}\end{array}$ & $\begin{array}{c}726 \\
0=\mathrm{JPL} / \mathrm{TRW} \\
\& \text { DGE "Rumors" }\end{array}$ & $\mathbf{P}$ & $\mathbf{s}$ & $\begin{array}{r}I(s) \\
E(s) \\
\operatorname{RSD}(s)\end{array}$ & $\begin{array}{r}I(s) \\
\operatorname{RSD}(\mathrm{s})\end{array}$ & $\begin{array}{l}A(c) \\
M(c) \\
L(c)\end{array}$ & $\begin{array}{l}\text { Info drawn largely } \\
\text { from earlier JPL/ } \\
\text { TRW studies, supple- } \\
\text { mented by reports as } \\
\text { they came in from } \\
\text { T.I.C. Vol. I Docu- } \\
\text { mented/1llugtrated } \\
\text { need for NEA-type } \\
\text { Incentives. Also } \\
\text { showed RSD prfori- } \\
\text { tes. Illustrated } \\
\text { that most RSD payoff } \\
\text { would cone from low- } \\
\text { ering cost of the } \\
\text { Geofluld (Well- } \\
\text { oriented). }\end{array}$ \\
\hline $\begin{array}{l}\text { GELCOM - Geothermal } \\
\text { Level1zed Busbar Cost } \\
\text { Model/MITRE }\end{array}$ & $78(?)$ & & & . & & & & & & $\begin{array}{l}\text { Documented MITRE's } \\
\text { site-specific cost- } \\
\text { of-power model. }\end{array}$ \\
\hline
\end{tabular}

1. Scenario Types: MA = Market Assessment, PS = Planning Scenarto, SP = S1te Prospectus, IP = Implementation Plan

2. Utilization: E = Electric, D = Direct Applications

3. Resource Considerations: $726=$ USGS Circ.726, $790=$ USGS Circ.790, $S=$ State data base, $0=0$ other, $N=$ None.

4. Demand Considerations: $P=$ Paper study, F = Field Work (outreach)

5. Economic Assessment: $G=$ Generic, $S=$ site-specific, II = Hybrid, Generic modified by site-specific conditions, $N=$ None

6. Requirements Identification: $I=$ Institutional, $E=$ Environmental, H\&D = Research \& Development, (g) $=$ generic, $(s)=s I t e=s p e c i f i c$, ( $(\mathrm{s})=$ none

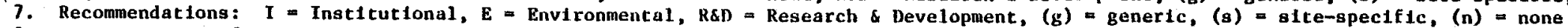

8. Documentation of: $A=$ Assumptions, $M=$ Models, $L=L+m i t a t i o n s, ~(c)=$ conplete, $(p)=$ partial, (n) $=$ none 
TABLE 3B-X̃XIV

KEY TO MAPS WHICH SHOW SCENARIO COVERAGE

Regional Scenarios

1. Western New York

2. Atlantic Coastal Plain

3. Southern Arkansas

4. Central Illinois/Indiana

5. Western South Dakota

6. Snake River Plain

7. Vale-Weiser-Ontario

8. Geysers

9. Imperial Valley

10. Nevada (26 regions)

Alaska

11. Barrow

12. Kiana

13. Nome

14. Pilgrim H.S.

15. Huslia

16. Manley H.S.

17. Clear Creek H.S.

18. Chena H.S.

19. Capital (Willow)

20. Klawasi

21. Tenakee Springs

22. Baranof

23. Bell Island H.S.

24. Wrange11

25. Adak

26. Umnak

27. Nikolski

28. Unalaska

\section{Hawail}

29. Puna

Washington

30. 01ympic Sol Duc H.S.

31. Baker H.S.

32. Mt. St. Helens

33. Mt. Ranier

34. Indian Heaven

35. Mt. Adams

36. Yakima

\section{Oregon}

37. Brietènbush H.S.

38. Carey H.S.

39. Mt. Hood

40. LaGrande

41. Belknap/Foley

42. Newberry Caldera

43. Burns Butte

44. Vale

45. Ontario

46. McCredle H.S.

47. Klamath Falls

48. Summer Lake

49. Crump Springs

50. Lakeview

51. Alvord 
KEY TO MAPS WHICH SHOW SCENARIO COVERAGE CONT'D

Idaho

52. Washington Co. (Weiser)

53. Crane Creek

54. Vulcan H.S.

55. Ada Co. (Boise)

56. Castle Creek

57. Bruneau/Grandview

58. Mountain Home

59. South Central Idaho (Twin Falls/Buhl/Hailey/Sun Valley)

60. Magic H.S.

61. Raft River

62. Conda

63. Madison Co. (Rexburg)

64. Yellowstone/Island Park KGRA

Montana

65. Deerlodge

66. Warmsprings

67. Broadwater

68. Marysuille

69. Boulder H.S.

70. Barkels H.S.

71. New Biltmore H.S.

72. Ennis

73. West Yellowstone

74. Corwin Springs

75. Bozeman

76. Hunter H.S.

77. White Sulfer Springs

Wyoming

78. Auburn

79. Little Sheep Mtn. Spring

80. Midwest/Salt Creek

81. Saratoga
South Dakota

82. Diamond Ring Ranch

83. Haakon

84. Kyle

85. Pierre

California

86. Glass Mountain

87. Kelley's H.S.

88. Surprise Valley

89. Lassan

90. Susanville

91. Geysers/Calistoga

92. Mono/Long Valley

93. Coso H.S.

94. Mecca

95. Salton Sea

96. Heber

97. Brawley

98. E1 Centro

99. East Mesa

Nevada

100. Steamboat Springs

101. Reno

102. Brady/Hazen

103. Stillwater/Soda Lake

104. Leach H.S.

105. Beowawe

106. E1ko

Utah

107. Ogden/Hooper/Hil1 AFB

108. Wasatch/Beck's/Hobo

109. Sandy 
TABLE 3B XIV Cont ${ }^{\top} d$

KEY TO MAPS WHICH SHOW SCENARIO COVERAGE CONT'D

\section{Utah (Continued)}

110. Crystal H.S.

111. Tintic

112. Abraham

113. Sevier Lake/Black Rock/ Desert/Delta

114. Cove Fort/Sulfurdale

115. Meadow/Hatton

116. Joseph H.S.

117. Roosevelt H.S.

118. Monroe/Red Hill/Johnson

119. Thermo H.S.

120. Veyo

121. LeVerkin

122. Bery1

Colorado

123. Juniper

124. Craig

125. Routt/Steamboat

126. Brand's Ranch

127. Hot Sulfur Springs

128. Haystack Butte/EIdorado

129. Idaho Springs

130. Glenwood H.S./South Canyon/Penny

131. Rhodes/Hartse11

132. Cemet $\mathrm{Cr}$./Ranger/Conundrum

133. Colonel Chinn

134. Orvis/Lemon

135. Ouray/

135A. Paradise/Dutton/Rico/Geyser

136. Tripp/Trimble/Pinkerton/Mound

137. Mt. Princeton/Brown's Canyon/ Cottonwood $\mathrm{Cr}$./Hortense

138. Waunita
Colorado (Continued)

139. Poncha/Cebolla/Wellsville/ Swissville

140. Canyon City/Freemont/Florence

141. Mineral/Valley View

142. Don K. Ranch

143. Clark Well

144. Wagonwheel Gap/Antelope/ Birdsie

145. Shaws

146. Sand Dunes

147. Splashland

148. Dexter/McIntyre

149. Pagosa Springs/Rainbow/Eoff Well

150. Dutch Crowley/Stinkling Springs

Arizona

(22 utilization studies)

151. Chandler

152. Safford

New Mexico

153. Valles Caldera

154. Lower San Francisco

155. Animas

156. Radium Springs

157. Kilbourne

Texas

158. Waco Tanks

159. Riudosa

160. Corsicana

161. Marlin

Maryland

162. Crisfleld Well 


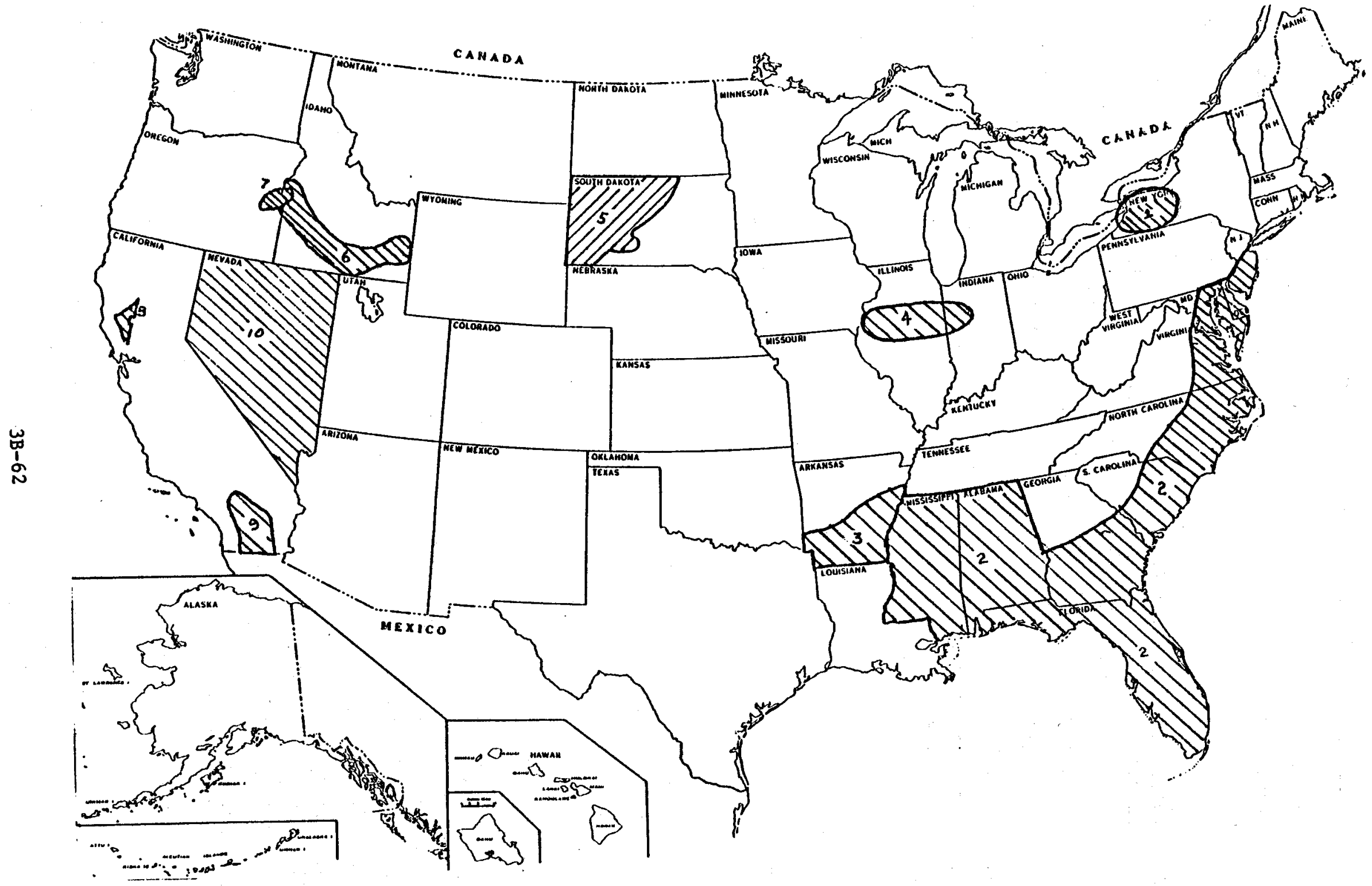

REGIONAL PLANNING SCENARIOS

FIGURE 3B-1 


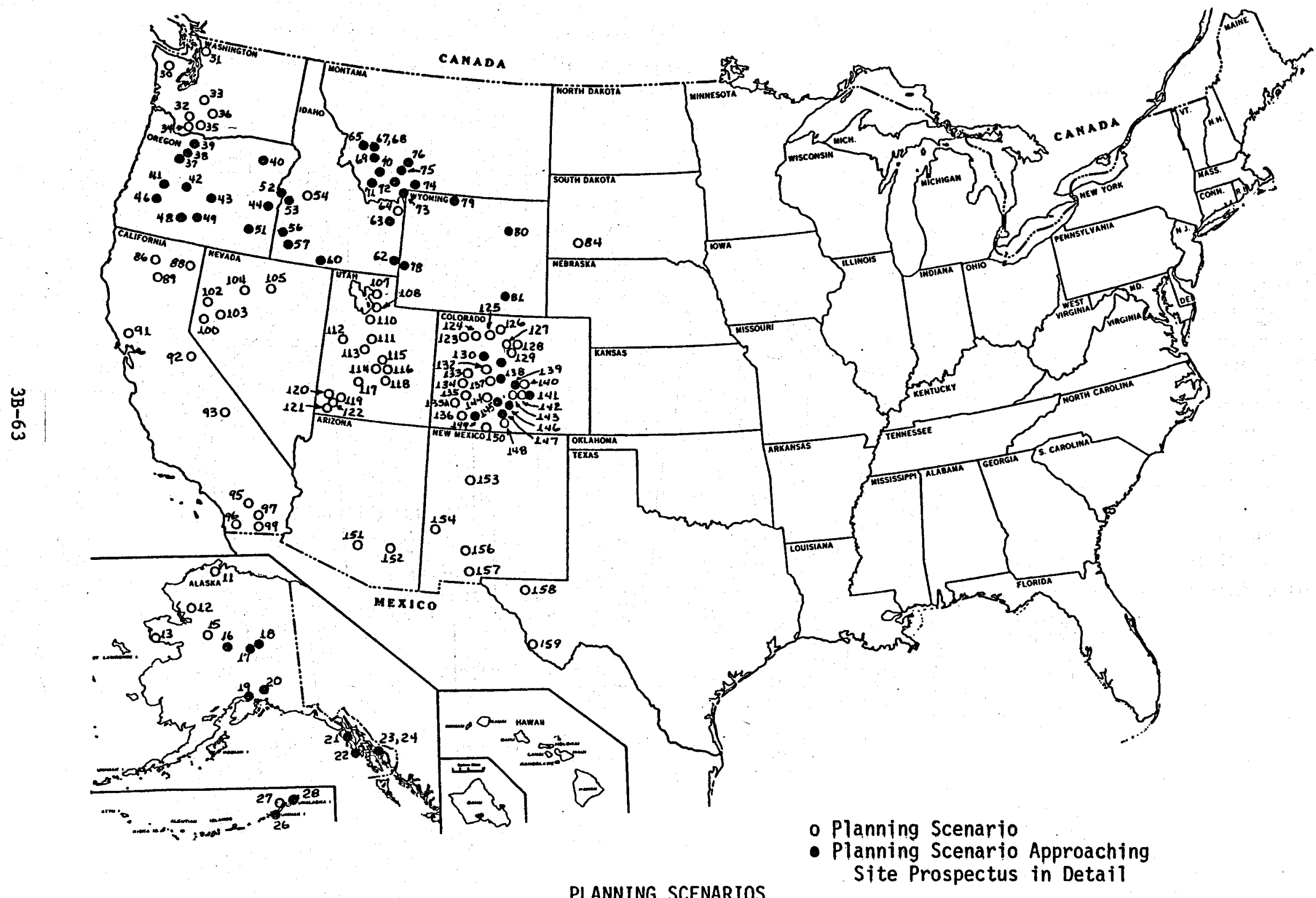

FIGURE 3B-2 


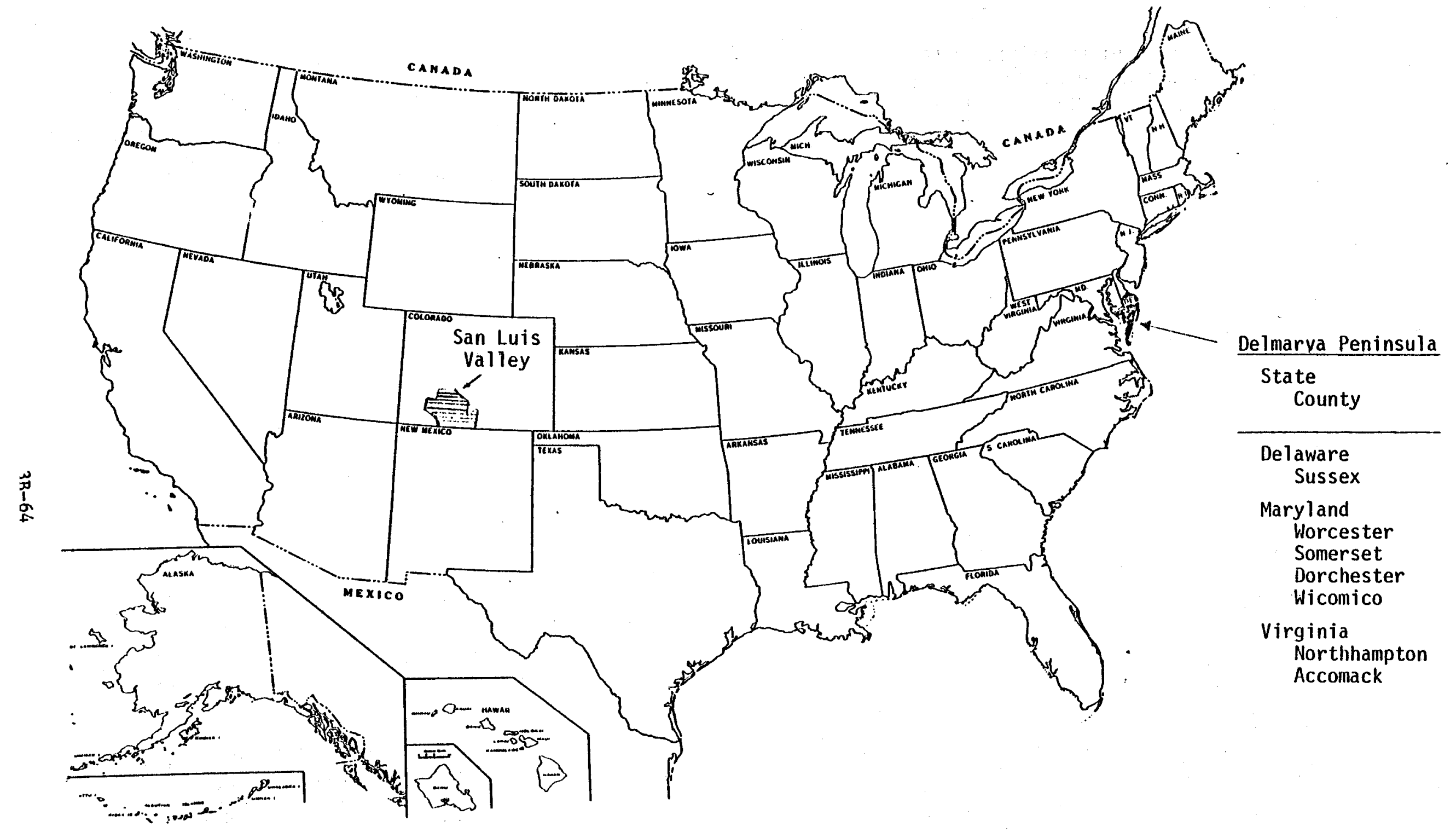

SITE PROSPECTUS

LOCATIONS 


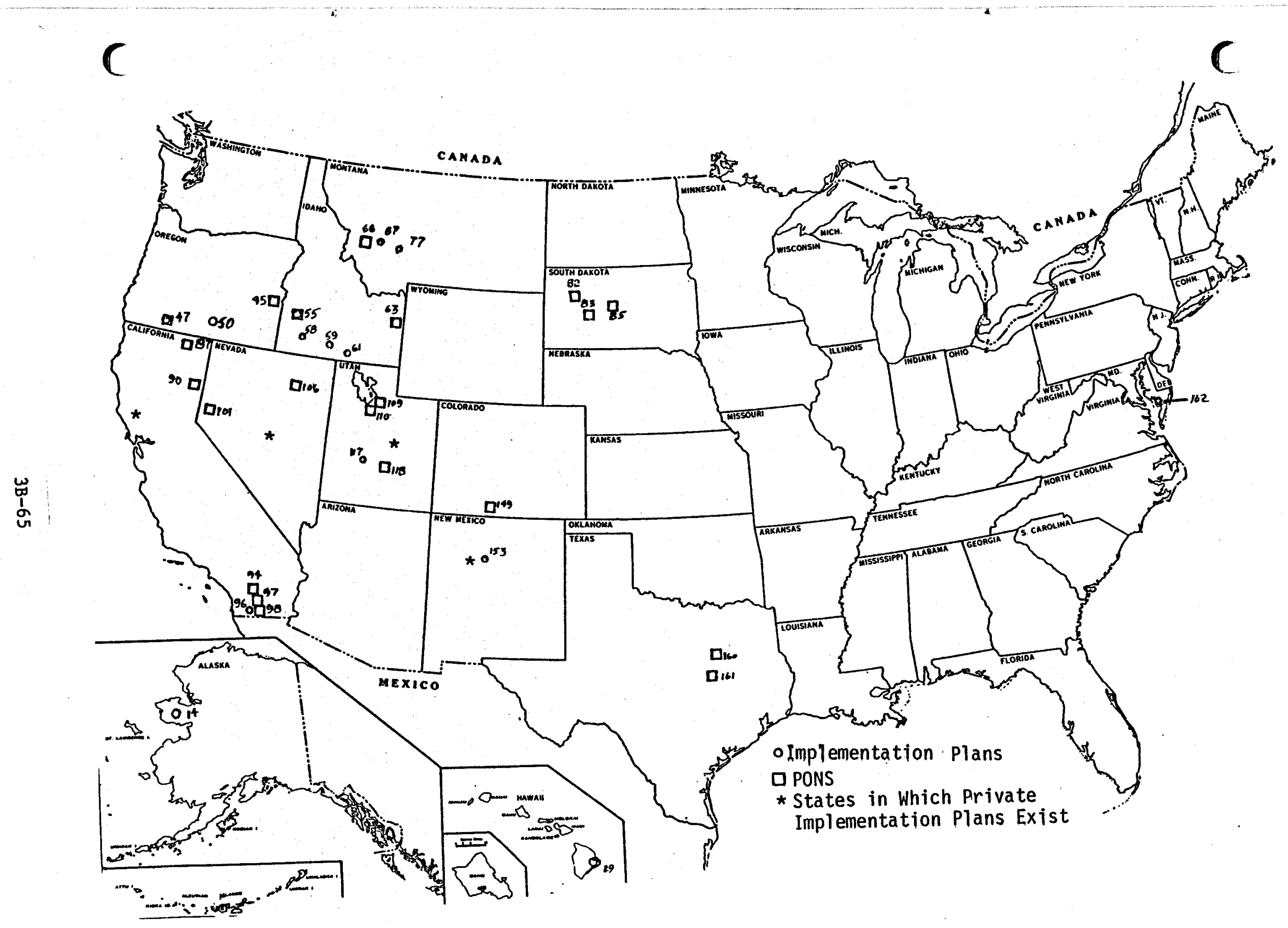

LOCATIONS HAVING IMPLEMENTATION PLANS

FIGURE 3B-4 


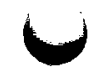

APPENDIX 3C

RECOMMENDATIONS FOR FUTURE SCENARIOS

$3 c-1$ 


\section{RECOMMENDATIONS FOR FUTURE SCENARIOS}

The five general types of scenarios used to date as planning and marketing tools for geothermal energy are:

1. Market-Resource Assessment

2. Planning Scenario

3. Site-Prospectus

4. Geothermal Site Schedule

5. Programmatic Implementation Plan

A narrative description of each of the above is to be found elsewhere in this report. Recommendations for future scenarios are as follows:

A. Establishes National Goals, and Identify Required Effort

The establishment of quantitative measures of the energy available from known geothermal areas, and the maximum utilization of the resource area by the market projected to be in place vs. time are required. The aggregation of such scenarios becomes the national goal for geothermal energy development, and further provides a detailed-local method of monitoring progress toward the attainment of the goals. Obviously as new geothermal areas are discovered or as new techniques become available which extend the range of energy extraction from existing resources, these will require either new or revised scenarios. The first two types of scenarios accordingly we suggest are required for all potential geothermal resources for the entire USA. These can be regional, state-wide or detailed for each specific resource area, whichever is most convenient. 
The other major requirement on the national level is the identification and documentation of the effort required to provide a base for the prompt, economic, and environmentally acceptable use of geothermal energy. This requirement is partially served by the first two types of planning effort listed above, where area-wide or local, legal, institutional issues and recommendations are surfaced and documented. These lists of issues have not been systematically collected in the past, and it is recommended that they be so in the future. Table 3C-I through VI lists the planning documents that have been written to date. This list also suggests what resource areas have not been analyzed. If this effort is currently planned and scheduled it is so noted.

B. Stimulate Action to Apply Geothermal Energy, and Identify Required Effort

The process of stimulating action involves the increasing of the local awareness of the details of local geothermal resources, specific methods of use and the equipments required, the economics of the energy production vis-a-vis alternate energy forms, the life expectancy of the resource, the mechanics for resource management, the environmental, socioeconomic, institutional, and legal issues of geothermal energy. Finally, if Federal programs are in progress which significantly contribute or effect any of the above - to inform the area of their content and schedule.

The site prospectus can be a marketing tool to perform the above functions. These need to be written where education and stimulus is 
necessary, or where the writing of a plan of the process of application of geothermal energy from beginning to end would be useful. For example, if the application is new and has not been done in that area before, than all the steps, laws, procedures, and permits are not ready and in place. The writing of this plan can expedite and assist the process of developing interest, get the pre-requisite laws, procedures, etc. written and in place and get the developer through the process.

The planning attendant with the Site Prospectus preparation is often at a very detailed level and accordingly necessary and desirable effort, and R\&D and engineering not identified previously surfaces and is documented and action can be taken.

Table C3-II and C3-V Iist the Site-Specific scenarios written to date and those planned for the current fiscal year. 
TABLE 3C-I

LIST OF FINISHED OR TO BE COMPLETED - PLANNING, OR STRAWMAN SCENARIOS PLANNING, OR STRAWMAN EFFORT

DONE

Eastern USA (35 States East of Rocky Mts, Including Puerto Rico)

Direct Applications (APL/JHU)

1. Western South Dakota

2. Oglala Sioux At Kyle, South Dakota

3. Southern Arkansas

4. Atlantic Coastal Plain

Combined Direct \& Electric (APL/JHU)

1. Eastern Gulf Coastal PIain

\section{California -}

Electric - JPL/SDC/SAI/MITRE

Geysers Region

Imperial Valley

Eastern Sierra Region

Northeast Region

Coso Hot Springs

Direct Application SAI - Started

Hawaii

Electric

Puna area

Direct Application

None
YET TO BE DONE

\section{Eastern USA}

Direct Applications

Deep sedementary Basins

APL

Fault Zone -

$" \quad " \quad$ APL / JHU
SCHEDULE

No

Yes

No
Electric

State of California Not will decide
Direct Application

all areas need to be completed plus*

Central Coastal Region -

to be done by or through

the State of California

\section{Electric}

See Note

Direct Application

Scenarios for the $13 \mathrm{re}-\quad$ No source areas*

Engineering Feasibility Study

required for site

NOTE: Puna is an active volcano area and accordingly it is not obyious that an electric generating facility cnuld be built.

* The Planning scenario could be preceded by a market assessment document. 
TABLE 3C-II

LIST OF FINISHED OR TO BE COMPLETED -

SITE PROSPECTUS OR GEOTHERMAL SITE SCHEDULE

DONE

Eastern USA ( 35 States
including $\left.P . R_{.}\right)$

Direct Appllcation

Delmarva area (MD, VA AND DE)
YET TO BE DONE

Eastern U.S.

Direct Application (APL/JHU)

Southern New Jersey

Norfolk Area

Coastal Plain

North Carolina

South Carolina

Georgia

California

Electric

Imperial valley

Nonelectric

Hawali

Electric

Puna - wellhead generator

Nonelectric

None
State of Calfornia to decide.

State of California to decide.

See Note Table 3C-I

DOE/RA or State of

Hawail to decide
SCHEDULE

Yes

Yes

Yes

Information not available

Information not available

No

No 


\section{PLANNING SCENARIOS}

\section{DONE}

Regional Hydrothermal Commercialization Plan, Rocky Mountain Basin and Range Region, Chapter V for

Vale-Weiser-Ontario)

Snake River Plain $\}$ Direct Applications

Cove Fort Eleçtric

Summary Report, Southwest Regional Operations

Research Program for:

Utah

Colorado

New Mexico

Arizona

Nevada

$\underset{\substack{1 \\ 1 \\ \infty}}{\longrightarrow}$

OIT work for:

Alaska (13 sites)

Idaho (11 sites, about $\frac{1}{2}$ Include electric 2 areas)

Oregon (13 sites)

Washington ( 6 sites)

Wyoming ( 4 sites, one in the Madison)

Montana (13 sites plus Madison area)

MITRE Planning Scenarios (Electric) for:

California (Brawley, Coso, East Mesa, Geysers,

Glass Mtn, Heber, Lassen, Mono-Long

Hawail (Puna)

Valley, Salton Sea, Surprise Valley)

Oregon (Alvord, Vale Hot Springs)

Washington (Baker Hot Springs)

Idaho (Bruneau-Grandview, Raft River, Welser-Crane Creek)

Nevada (Beowawe, Brady Hot Springs, Leach, Steamboat Springs)

Arizona (Chandler, Safford)

New Mexico (Valles Caldera)

Utah (Cove-Fort sulfurdale, Roosevelt Hot Springs, Thermo)
Refinements for:

Utah

New Mexico

Arizona

Nevada

Need first cut for: North Dakota

Texas

not scheduled to start in FY79

under way 
TABLE 3C-IV

MARKET ASSESSMENTS

DONE

$\left.\begin{array}{cc}\hline \text { Rocky Mountain Basin and Range Market Penetration } & \text { Alaska } \\ \text { Analysis for: } & \text { Oregon } \\ \text { Arizona } & \text { Texas } \\ \text { Colorado } & \text { Washington }\end{array}\right\}$

SCHEDULE

Under way

亗

Idaho

Montana

Nevada

New Mexico

North Dakota

South Dakota

Utah

Wyoming 


\section{SITE PROSPECTUS}

DONE
YET TO BE DONE

SCHEDULE
Starting FY 79

Two Strawman scenarios exist for South Dakota, i.e., the western half of the state and the Oglala Sioux at Kyle.

It is planned that these be redone to

be consistent with other western states.

Information Sertes 9

Geothermal Energy Development in Colorado:

Processes, Promises and Problems

for 30 communties in Colorado

$\left.\begin{array}{l}\text { Alaska } \\ \text { Texas } \\ \text { Oregon } \\ \text { Washington }\end{array}\right\}$

Not

Scheduled

Sites with greatest potential will

have highest priority. 
TABLE 3C-VI

GEOTHERMAL SITE SCHEDULE

DONE

YET TO BE DONE

SCHEDULE

Detafled Devélopment Scenario, Roosevelt Hot Springs

$\underset{⿱}{\mathfrak{L}}$
One electric and one direct application

as appropriate for each of the follow-

ing states:

Idaho (direct application underway)

Utah (electric complete for Roosevelt)

Colorado

Nevada

Arizona

New Mexico

Start in

FY79

$\left.\begin{array}{l}\text { Alaska } \\ \text { Washington } \\ \text { Oregon } \\ \text { Texas }\end{array}\right\}$

Not

Scheduled

North Dakota

South Dakota

Montana

Possibly

FY80 


\section{APPENDIX 3D}

INTERNATIONAL USE OF GEOTHERMAL ENERGY

OR MARKETING OF UNITED STATES TECHNOLOGY

3D-1 


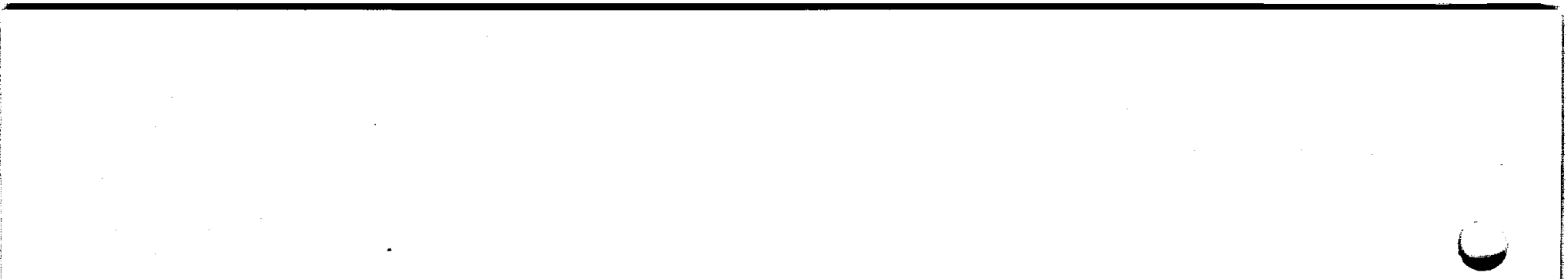


INTERNATIONAL USE OF GEOTHERMAL ENERGY OR MARKETING

OF UNITED STATES TECHNOLOGY

There are at least two functions relating to international use of geothermal energy of interest to the U.S. geothermal program. These are the extent, techniques, economics and history of its use for space conditioning. These data are useful since they have been users for many years, they have developed an infrastructure, and are replacing fossil fuel for space heating. Further, some have developed rather complex hybrid systems using geothermal together with heat pumps for space heating. The techniques for the reservoir engineering and management, the inducements for acting in the face of technical and economic risk, how the infrastructure evolved are all things of interest and may prove educational and models for U.S. actions.

The second area is to measure the ability of the international competition if the U.S. is planning to market geothermal technology or geothermal products.

These functions can be considered as a planning function. It is not obvious that any other planning internationally effort is warranted. 

APPENDIX 3E

THE NEED FOR ADDITIONAL PLANNING EFFORT TO ASSIST THE USE OF HYDROTHERMAL FOR SPACE HEATING

$3 E-1$ 

THE NEED FOR ADDITIONAL PLANNING EFFORT TO ASSIST THE USE OF HYDROTHERMAL FOR SPACE HEATING

The primary use of moderate temperature hydrothermal waters are either industrial process heat or space conditioning. By this division all forms of agricultural or agricultural products use of moderate temperature geothermal waters are listed under industrial process heat. On a national average the energy used for space conditioning is an order of magnitude greater than Industrial Process heat usage, for end use temperatures below $100^{\circ} \mathrm{C}$.

The application of geothermal to space conditioning is not an easy task, and most surely the applications by industry for process heat will be quilcker even though its potential for displacing oil is much smaller. The industrial use of geothermal will preceed space conditioning, i.e. district heating because it is more economical and less risky. For example it does not require a large distribution system; there is no heating utility to pay, there are no meters to read or bills to collect. If the industrial user is big enough he can drill his own series of wells consistent with permitting and environmental requirements. If the legal situation is such that royalties are required and litigation is likely to be minimal, i.e., pooling regulations are clear and unambiguous, the economics of geothermal energy, i.e. the cost per million BTU's for a single user colocated near a resource, is attractive enough that industry will consider its development. There is a common concern to all developers of geothermal energy in regard to the economic consequences of 
lack of reservoir management. However, the industrial user has a much greater cost margin and accordingly is not as sensitive to changes in well productivity or decreases in temperature. Finally industry only has to convince itself that geothermal energy is a viable, economic, and dependable resource to take action. Industries which are in place and operating are busy and unless they have real problems someone has to carry the message to them. The Site Prospectus in the hands of state and local planning groups, economic deve1opment groups and affiliated trade organizations can be of considerable assistance to the potential industrial user. The document and the local people who help develop it can advise him of the Federal and local interest and activity in geothermal in the area, and assistance available. Further with the attendant road map all the necessary steps, incentives, and hurdles are spelled out to expedite and assist his program of application.

In the case of space conditioning using geothermal energy many things are much different. The economics i.e., dollars per million BTU are at best close to or just below competitive fossil fuels, even for the case of new construction of moderate to high density living space.

In the case of retrofitting of existing housing stock the real costs are very difficult to accurately estimate except to say that it will cost more than new construction. A second plus for new construction is that the developer knows the size of the system to be 
supplied and its geometry. In the retrofit case there is no assurance of the extent of penetration of a community unless it were possible to direct it by fiat. Finally the legal definitions of the ownership of geothermal energy can pose a most significant deterrent to the development of geothermal for space conditioning. If the law is ambiguous, as is the case in Maryland, or if the ownership rests with the surface-estate owner, and the state has not defined the mechanics and requirements for pooling and unitization and royalties, then the developer is faced with the possibility of litigation. In the case already made that the economics are marginal at best the developer cannot and will not risk undefined litigation. You might well ask, then, with all these problems will anyone consider geothermal for space conditioning? We think so, however, it will require a considerable effort by the Department of Energy and its agents to clarify these issues and make opportunities rather than disincentives for development. The Site Prospectus is the best mechanism we see for identifying these problems. Since the Prospectus is done by or in conjuction with local and state personnel, a mechanism is thereby provided in that these informed people, having identified the problems, may initiate effort for their solution. 
APPENDIX 3E

GUIDELINES FOR DEVELOPING SITE PROSPECTUSES

$3 F-1$ 


\section{INTRODUCTION}

The following guidelines are those used by the ten states in the Rocky Mountains and Basin and Range area. In the Eastern United States a slightly different procedure has been used. Here the regional research operations contractor or the equivalent together with state agency planning i.e., geologic office, water rights office, and/or energy office personnel, evolve the Prospectus through detailed interaction and workshops with community and appropriate industrial, agriculture, food processing industry. The industrial sector having been identified by a precursor market survey. Guidelines for Developing Site Prospectus in the West

1. Utilize an outreach person (e.g. state planning team member as is done in RMB\&R region).

2. Develop a strawman site prospectus. This activity

a) assures that the outreach person does his homework before going into the field. He will know the resource, potential applications, institutional requirements, financial incentives, and other information.

b) provides a framework for discussions with local people

3. Make contact with local planning departments, chamber of commerce, government officials, business people and interested citizens to determine local environment, needs and desires. Community workshops are effective in establishing contacts.

4. If uses desired by the community do not presently exist, contact representatives from appropriate industries to determine feasibility of having those industries at the site.

5. Perform iteration on Step 3 with the information found in Step 4. 
6. Modify the site prospectus to include community and industry input. The result is a realistic depiction of how hydrothermal development might occur at the site.

7. This document becomes tool for local planners and deve1opers. 


\section{APPENDIX 3G}

ALTERNATIVE USER-ORIENTED SCENARIOS

$3 G-1$ 


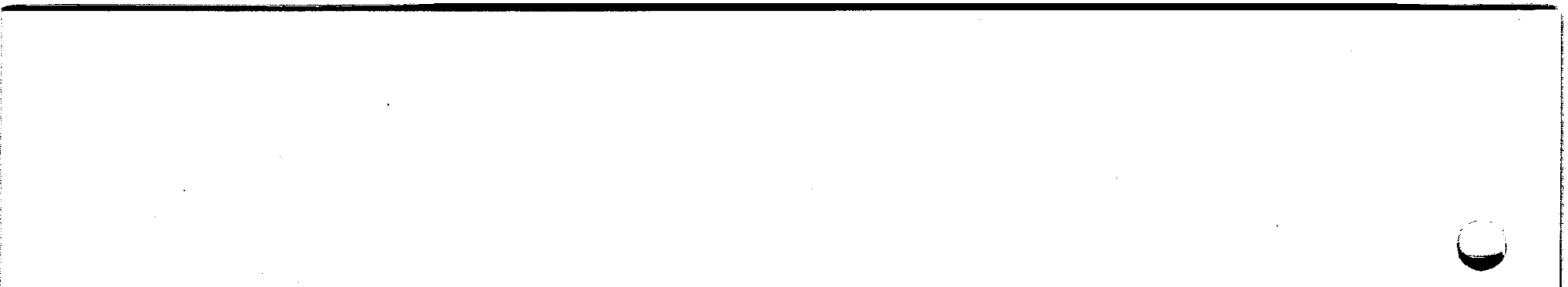


ALTERNATIVE, USER-ORIENTED SCENARIOS

All geothermal scenarios which have come to the attention of this group have been resource-oriented, that is to say, the primary consideration is directed at specific resources or resource areas. We are aware of other generic studies of industrial applicability of geothermal energy, but not of any which attempt to develop industryoriented development schedules which identify and employ decisionmaking milestones and timing. (The MIT pulp and paper industry study now underway is reportedly an exception.) We suggest that this imbalance should be redressed.

Because commitments to use geothermal resources will require the confluence of a resource and a user, there is a need to develop an understanding and a view of how a user (e.g., an industrial firm) could employ a typical resource. This understanding must extend beyond the obvious engineering, transportation, and site parameters to considerations of the institutional setting requirements. Timing and phasing considerations of corporate committments and decisions should also be clearly understood. From this base of understanding, descriptive schedules of corporate (or municipal) steps on the road to committment and through to construction and ultimate use should be developed. These schedules, or industrial scenarios, can then be overlaid upon resource (site-specific) development plans to obtain an integrated understanding of geothermal utilization. 
The priorities for developing industrial development plans could be based on generic industrial studies that may have already been performed and identify those industries that are the most likely targets. Also, priorities may be suggested, and user-specific understanding may be derived from examination of private sector responses to Federal Program Research and Development Announcements for direct applications.

We believe that user-oriented scenarios used by themselves or in conjunction with resource-oriented scenarios could meet many important commercialization needs. Among them:

- clarification of marketing targets

- estimating rates and amounts of market growth

- matching of appropriate user targets to prospective resources

- marketing aids for use in approaching potential users

- the identification of research development needed to make geothermal resources attractive to potential users.

- the identification of legal and institutional issues, i.e., resource ownership, resource assessment and engineering, and resource management, that affect economics of application and commitment to proceed.

Finally, we do not suggest that efforts to refine and update resource-oriented scenarios or to extend their coverage to new areas be curtailed. We only suggest that a set (of as yet undefined scope and specificity) of user-specific development schedules be derived to complement the resource-oriented scenarios and to provide the required resource-user information matches needed to facilitate commercialization planning and implementation. 


\section{PROGRESS MONITORING}

\section{SECTION 4}

4-1 


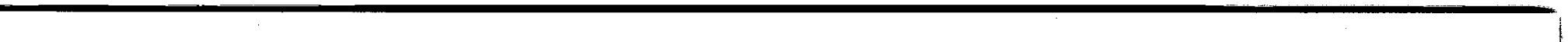

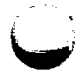

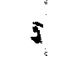


NATIONAL GEOTHERMAI PROGRESS MONITORING ASSESSMENT

\section{COMMITTEE MEMBERS}

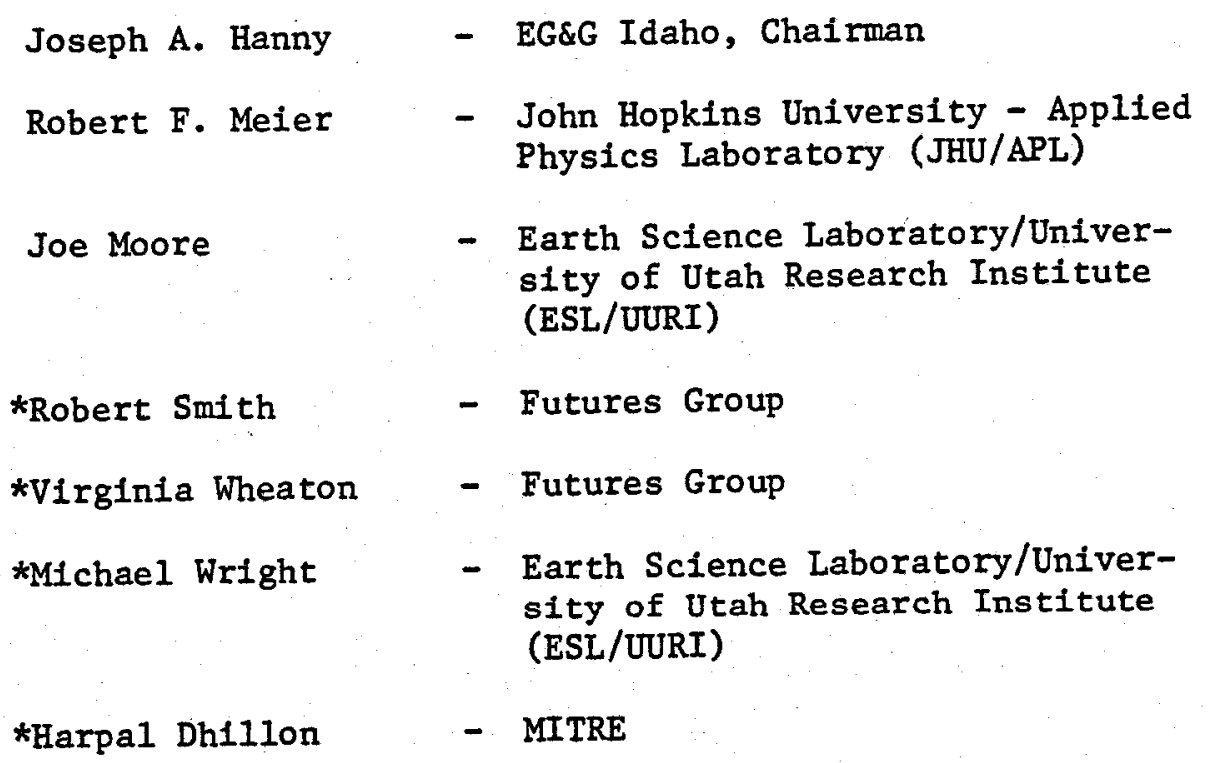

* Part time participants 



\section{SUMMARY}

A committee was formed at the DOE-RA review meeting held at McLean, Virginia January 29 through February 8, 1979 to evaluate the previous efforts to design and/or implement progress monitoring systems for geothermal energy commercialization. The committee consisted of representatives from DOE contractor organizations that have been participating in various planning or support functions directly related to geothermal energy commercialization.

Progress monitoring is necessary for the following reasons:

1. Provide input to program planning

- Set priorities

- Early warning of program problems

- Aid in realignment of program resources

2. Measure program effectiveness

3. Support public awareness

4. Support PL 93-410 reporting requirements

The approach selected by the committee for completing this assessment is outlined as follows:

1. Review existing documentation.

2. Determine the need for progress monitoring.

3. Determine the requirements for progress monitoring (essential and desirable).

4. Identify data sources, determine the collection processes and the method of data distribution.

5. Determine the need for data processing systems.

6. Recommend a plan for National Progress Monitoring. 


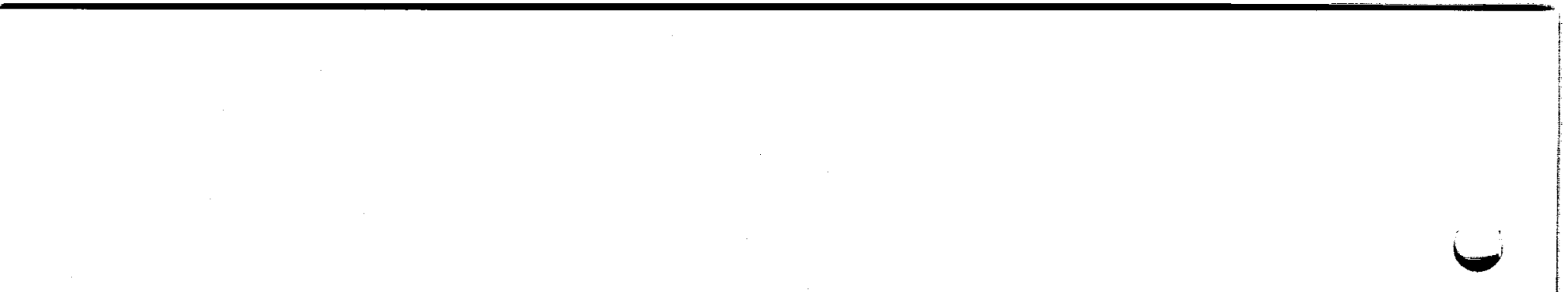




\section{EVALUATION OF EXISTING DOCUMENTATION}

Eight reports were avallable for consideration. These items range from a single sheet table matrix on resource utilization development indicators to published reports by various contractors. An evaluation was made of each document to determine the proposed scope of monitoring, the utility of each approach, and the apparent limitations for progress monitoring applications. Each of these are summarized as follows:

1. Systems Development Corporation, "Task 2 - Regional Program

Monitoring and Progress Evaluation", dated December 8, 1978.

This report summarizes the work on Task 2, Regional Program Monitoring and Progress Evaluation, for California and Hawail. The specific objectives of Task 2 are as follows:

a. To determine the existing status of power plant projects and future plans.

b. To Identify the major problem areas for each project (technical, financial and regulatory) which are holding up progress.

c. To analyze the data and make recommendations to DOE regarding the action which could be taken to alleviate problems.

This report recognizes and suggests solutions to technical, financial, and institutional problems in the region. The emphasis Is totally on electric power generation, does not consider direct heat applications, and does not include a data accumulation and aggregation system for monitoring. 
2. Science Applications, Inc., "Pacific Region Progress Monitor, Draft Fina1 Report", dated November 30, 1978.

This approach utilizes site specific scenarios for tracking progress for both electric and direct heat applications. Three stages of geothermal development are considered: Identification, Exploration, and Utilization. The report establishes indicators for tracking progress and suggests federal, state and local contact points for tracking information. This approach has limitations that should be considered:

a. Site specific scenarios must exist. These scenarios seldom exist in the identification phase.

b. The scenarios tracking method favors the electrical application of geothermal energy and would not lend itself to monitoring many of the direct heat activities.

3. "Project 2, Program Management System Active Summary", dated January $30,1979$.

This approach provides development plans for 27 high temperature sites on federal land, federal manpower estimates to complete selected scenario activities; provides outputs; planning schedules, resource reports (manpower and/or power-on-line profiles), exception reports (plans vs. progress), reporting format.

The current use is for specific sites on federal land only and is restricted to high temperature sites. Monitoring does not include permitting process or costs and only considers successful efforts. The current scope is not applicable to total exploration and commercialization activities. 
4. Lawrence Berkeley Laboratory "GRID" (Memo to L. Werner dated January 26, 1979).

A method to complle and evaluate geothermal data pertaining to basic science, utilization and environmental effects is presented in this report. This system features a computerized system for handling biographical and numerical data. No monitoring system is proposed for indication of commercialization progress.

5. Johns Hopkins University/APL, "Representative Management Planning Network for Moderate Temperature Geothermal Development and Application", dated July 20, 1978.

The scope of this report is to test MINIPERT capabilities for tracking geothermal activities. A sample case covers phases from Initial prospecting to power-on-line. Standard report forms available are presented. This report does not define essential vs. desirable monitoring points and does not address sources of information or how it would be obtained.

6. Johns Hopkins University/APL - "Summary Data Sheets", dated January 1, 1979.

Data sheets are prepared for several states particularly in the east and south. These sheets provide summary data base for prospective resources and lists state offices for initial contacts and current geothermal uses. These data are most applicable to levels 1 and 2 scenarios. The data sheets provide ready format for executive review and for updating as new data on resources become available. 
No site specific data are included. The data sheets provide only a very general overview and do not lend themselves to high density resource states.

7. Jet Propulsion Laboratory - "Resource Utilization Development Status Indicators", dated August 11, 1976.

This information is presented on a single sheet (possibly a page from another report) which indicates the sequence of five events from "Notice of Intent" for Federal (KGRA), Federal (Non-KGRA), State, and private leases to the permit approval stage. No progress monitoring system is proposed.

8. "Rocky Mountain Basin \& Range Region Hydrothermal Commercialization Activities Report" for December 1978.

This monthly report presents a summary of news items related to Industry, State, and DOE activities on a state by state basis (ten states). This report is made up from input by state planning and outreach teams and state resource teams which is submitted through EG\&G Idaho, Inc., and the Earth Science Lab, University of Utah Research Institute. This information is consolidated by the DOE Idaho Operations office and submitted to DOE-RA and DOE-ET. This system, of itself, does not track against a baseline but does provide rapid information to the resource manager on significant events that transpire in the region. 
COMMERCIALIZATION SEQUENCE

A typical sequence of significant events that occurs from the time resources are considered for leasing through utilization is illustrated in Figure 4-1 through 4-4. These charts were prepared to look for significant events that could be tracked.

Those geothermal activities considered as essential tracking points are listed as follows:

1. Leases Issued - The amount of information avallable will vary from state to state, by type of lease granted, and especially by source of lease. The federal lease data are the easiest obtained. Private leases are the most difficult and will, in most cases, require searching county records, The basic lease and permitting processes are outlined in Figure 4-5. Surface exploration may in some cases occur before leasing and in other cases after leasing. Table 4-I lists the most likely sources for obtaining lease and permit information.

2. Permits - These documents are normally 1ssued for surface exploration, exploratory drilling and field development, and construction activities. It may be necessary in some cases to search for construction permits that are co-located with drlling activity to avold searching through all construction permits.

3. Federal and State Regulation Changes - Policy changes will 
Influence geothermal energy utilization. These activities must be tracked and reported through the monitoring system.

4. Company Commitments - Forecasts and risk money obtained are good progress indicators. Surveys can be made periodically to determine commercialization trends. Electrical applications forecasts are frequently available through EPRI.

5. Operating Plant Economic Analyses - These studies will provide comparisons with other energy sources and will be valuable information guides for comercialization.

6. Technology Developments - Progress in providing lower cost and more reliable hardware for exploration and utilization should be reviewed periodically to establish trends.

7. Power On Line - The real "bottom line" of monitoring progress will be the Quads of geothermal energy being utilized and the equivalent barrels of oil saved.

The proposed method for acquiring the above essential information is discussed in "Proposed Monitoring System". 


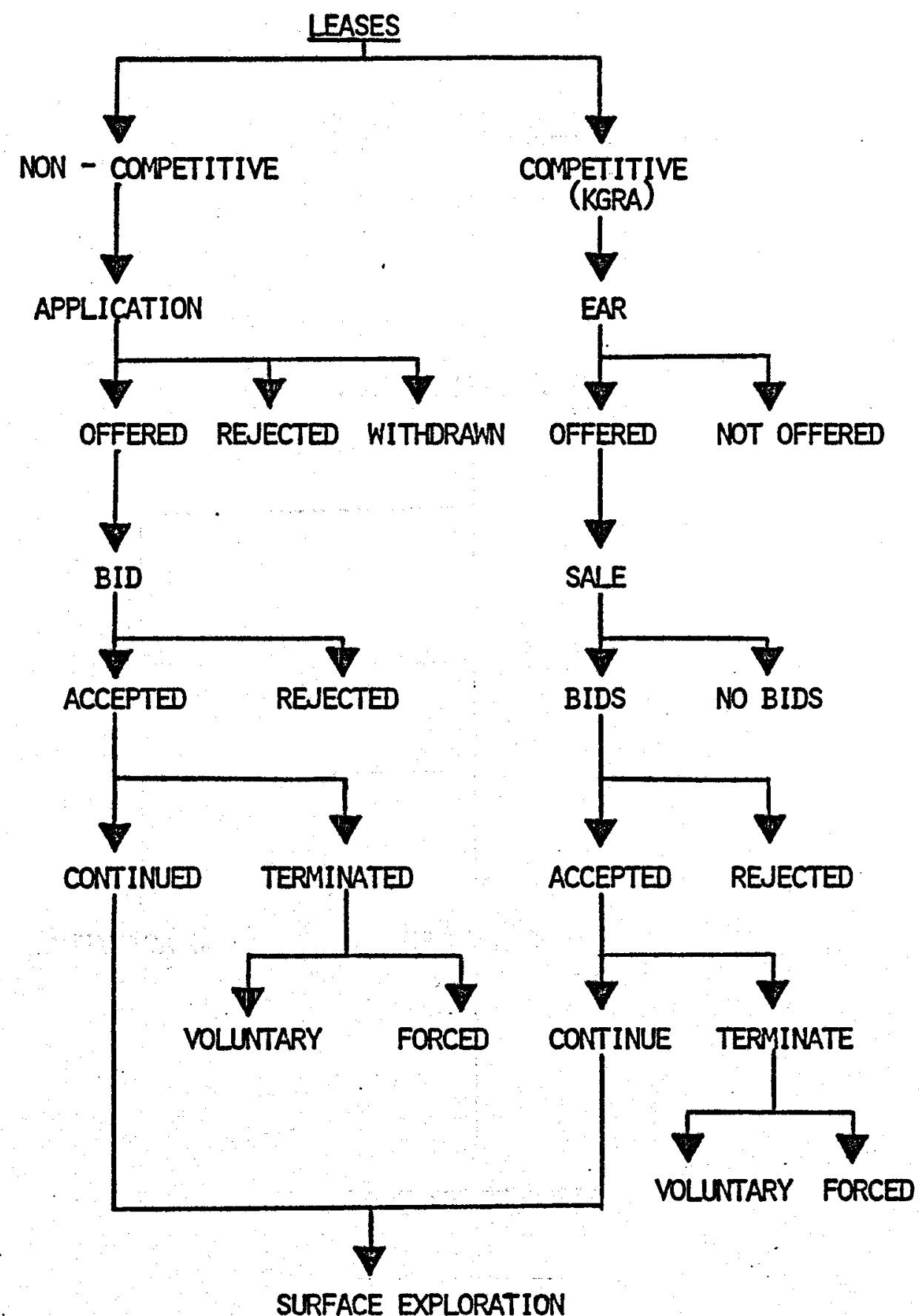

FIGURE 4-1 


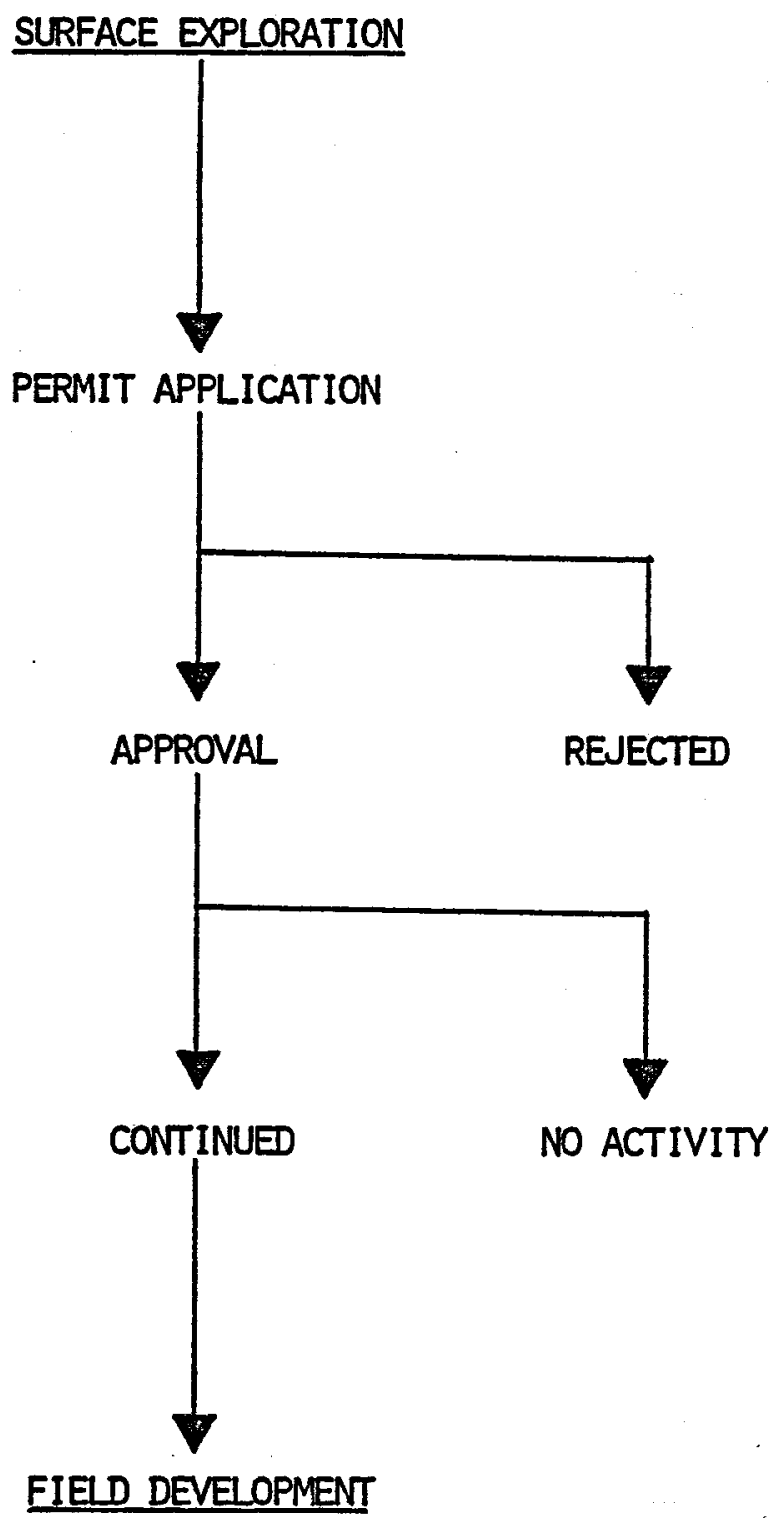

FIGURE 4-2

SURFACE EXPLORATION SEQUENCE 


\section{EIELD DEVELOPMENT}

PLANS OF OPERATION $(P .0,0$,$) AND DRILIING$ (MAY NOT ALWAYS GET P.0.0. S FOR DIRECT HEAT SYSTEMS)

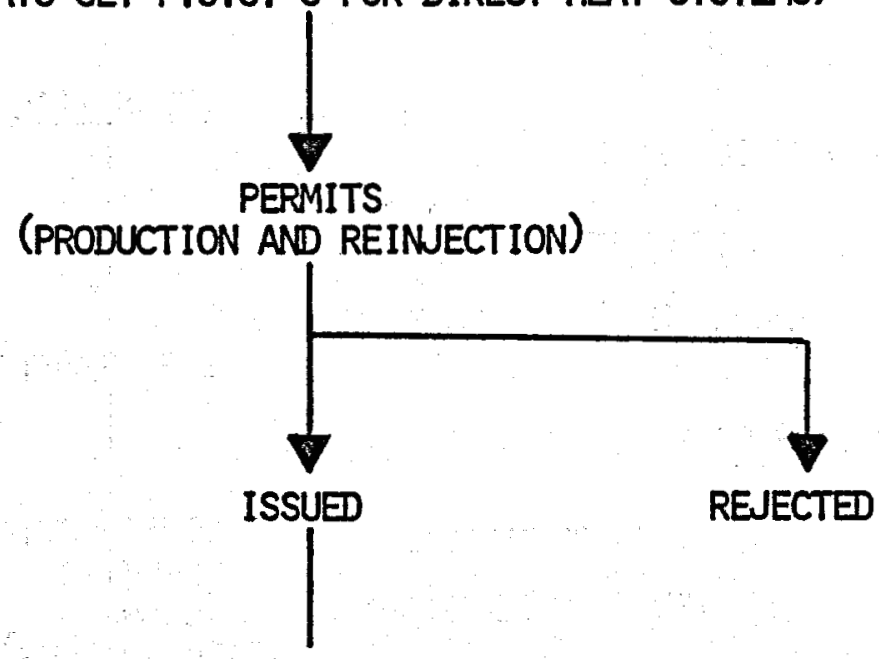

DRILLING

(FOR DIRECT HEAT THIS COUL BE THE SAME TRACKING POINT AS FIRST PRODUCTION HOLE - EXPLORATORY DRILIING）

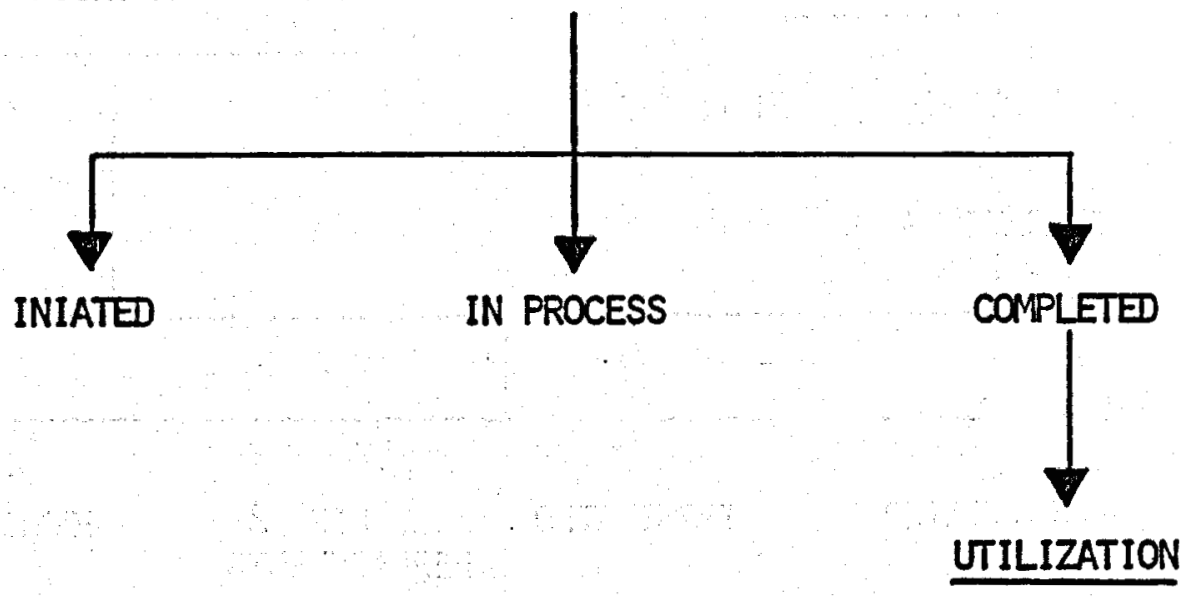

FIGURE 4-3 


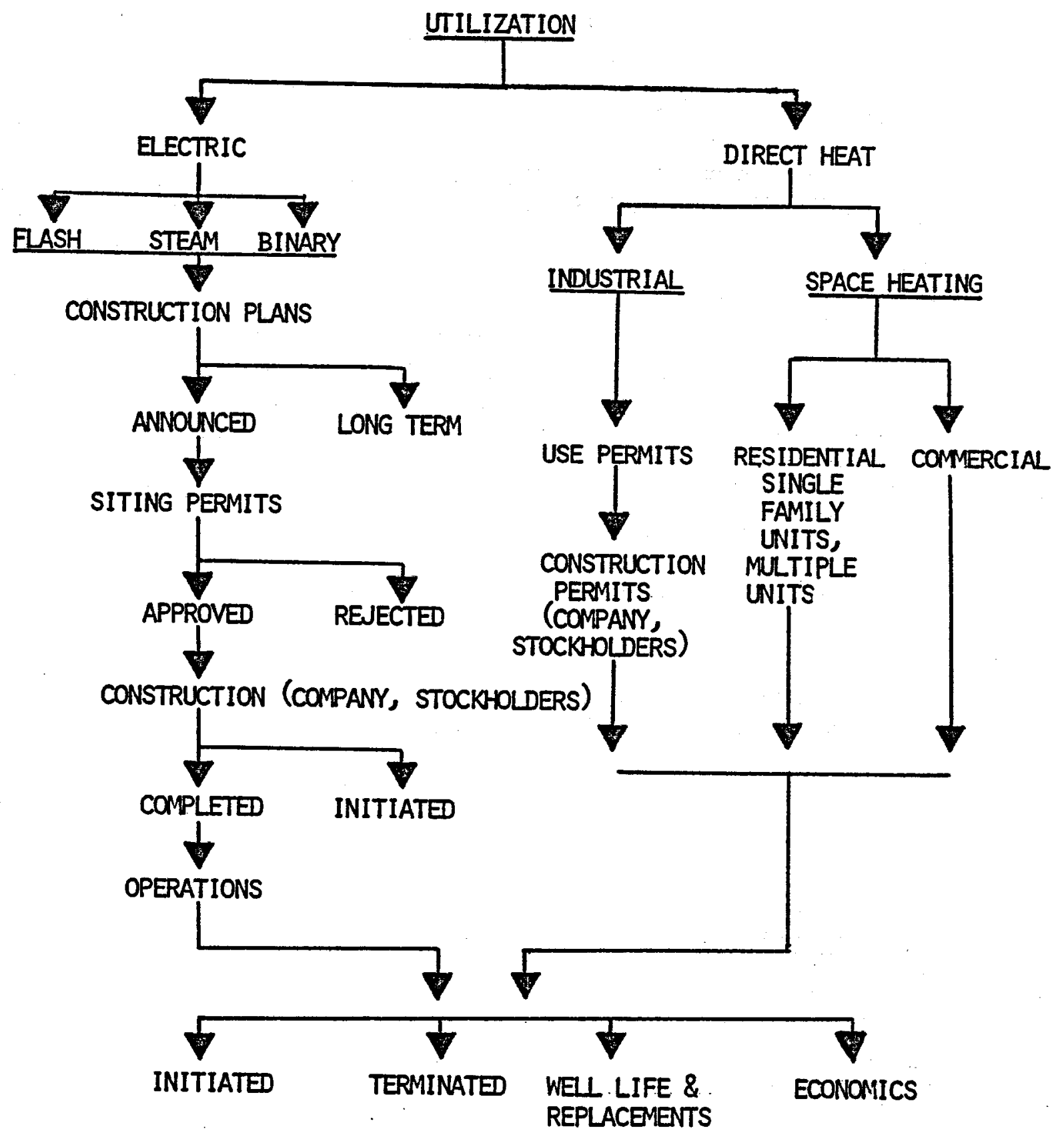

FIGURE 4-4

UTILIZATION SEQUENCE 


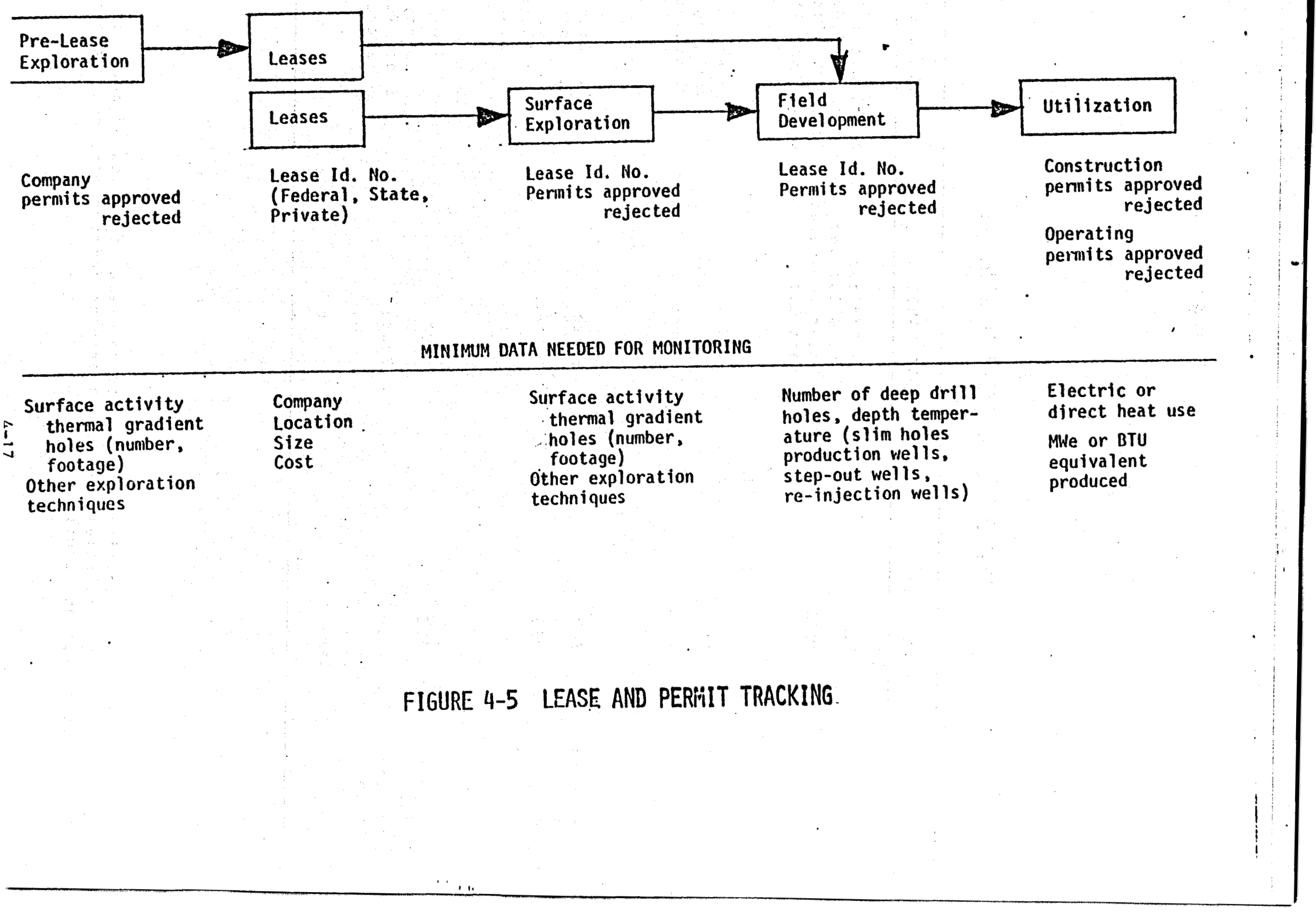


TABLE 4-I SOURCES OF INFORMATION

\begin{tabular}{|c|c|c|c|}
\hline & FEDERAL LANDS & STATE LANDS & PRIVATE LANDS \\
\hline $\begin{array}{l}\text { Lease } \\
\text { Data }\end{array}$ & $\begin{array}{l}\text { BLM } \\
\text { USGS }\end{array}$ & $\begin{array}{l}\text { State Offices } \\
-\quad 0 i l \& \text { Gas Comm } \\
\text { - Water \& Minerals } \\
\text { - land Use }\end{array}$ & $\begin{array}{l}\text { Difficult to obtain } \\
\text { Possibly County } \\
\text { Records. Accuracy } \\
\text { could be a problem. }\end{array}$ \\
\hline $\begin{array}{l}\text { Permits } \\
\text { For } \\
\text { Surface } \\
\text { Explora- } \\
\text { tion }\end{array}$ & $\begin{array}{l}\text { BLM } \\
\text { USGS }\end{array}$ & $\begin{array}{l}\text { State } \\
\text { Offices }\end{array}$ & $\begin{array}{l}\text { County - If } \\
\text { Drilling is } \\
\text { Involved }\end{array}$ \\
\hline $\begin{array}{l}\text { Permits } \\
\text { For } \\
\text { Field } \\
\text { Develop- } \\
\text { ment }\end{array}$ & $\begin{array}{l}\text { BLM } \\
\text { USGS }\end{array}$ & $\begin{array}{l}\text { State } \\
\text { Offices }\end{array}$ & $\begin{array}{ll}\text { 1. } & \text { County } \\
\text { 2. } & \text { Possibly- } \\
\text { State Water } \\
\text { Quality } \\
\text { Boards }\end{array}$ \\
\hline $\begin{array}{l}\text { Permits } \\
\text { For } \\
\text { Utiliza- } \\
\text { tion }\end{array}$ & $\begin{array}{c}\text { PUC } \\
\text { USGS } \\
\text { Forest } \\
\text { Service }\end{array}$ & $\begin{array}{c}\text { PUC } \\
\text { State }\end{array}$ & $\begin{array}{c}\text { PUC } \\
\text { County } \\
\text { State Water } \\
\text { Board }\end{array}$ \\
\hline
\end{tabular}

Note: Direct Heat Utilization permits may require review of colocated drilling activities to avoid. searching through many non-geothermal construction permits. 


\section{PROGRESS MONITORING FEATURES}

Criteria for development of a progress monitoring system that would fulfill the needs Identifled in the "Summary" have been prepared and are listed below:

1. Must have a high degree of accuracy and specificity on essential monitoring points.

2. Should be easily adaptable to both direct heat and electric applications monitoring.

3. Must have an accurate data base to provide a reference for progress comparison or trend analysis.

4. Should include a rapld identification of DOE program problems as well as major accomplishments.

5. Must provide a mechanism for obtaining and reporting data in areas where state teams are not established.

The documents previously reviewed have been interpreted with reference to the points established as desirable features for a progress monitoring system. Three generic types of potential monitoring systems now exist:

1. Concise state-by-state summary of status of geothermal development. This enables the executive to keep abreast of very general progress in states or resource areas;

2. Periodic listings of highlights within a region... These enable the executive to have many important and specific data avallable.

3. Computer supported systems for tracking specific scenarios (site speciflc or somewhat more generic). An evaluation of the three generic type monitors is presented in Table 4-II. 
PROGRESS MONITORING OPTIONS

\section{ADVANTAGES}

1. Scenario Based Computer Tracking (e.g. SAI Pacific Region Progress Monitor)
1. Easy way to track electric sys tems.

2. Aggregation easy to achieve.

3. Can handle many data and provide categorical information when desired.
DISADVANTAGES

1. Expensive to Maintain

2. Scenarios do not always achieve their intended use providing a false base.

3. Difficult to obtain scenarios for some direct heat systems.

4. Scenarios are not uniformly used and understood.

5. Baseline/Progress comparisons are often misleading if an accurate base is not achieved.

6. Won't easily handle study profiles.
2. RMB\&R Region Type Highlight Monitoring.
1. Rapid identification of major highlights.

2. Inexpensive

3. Early identification of suspect DOE program problems
3. APL Type Data Sheet System
1. Relatively easy way to summarize data in states where defined resources are limited in number and an $O . R$. type contractor has not been identified.
1. Baseline/Progress comparisons difficult.

2. Trend analysis against a baseline report necessary.
2. Relatively Inexpensive. Not suited to areas with a large amount of commercialization activity. 


\section{PROPOSED MONITORING SYSTEM}

The method selected by the committee is a combination of parts of previously proposed or existing systems. The selected approach to progress monitoring is summarized in Table 4-III. The use of software data processing systems is minimal and would be used primarily in aggregation of leasing and permitting data. Data accumulation would be accomplished by state teams already existing for planning and outreach functions in those states where teams are established. Other states that have limited identifled resources would require a "circuit" rider to contact a group of states (preferably by personal visit) semi-annually to update a baseline document. A data baseline report is essential for every state with numerous resources and possibly on a DOE region basis for all other states. The data baseline report should Include, as a minimum, Information on the following items:

1. Basic State Data

2. Hydrothermal Resources

3. Commercialization Activities

- Leasing

- Permitting

- Historical Highlights

- Operational Systems (Power On Line)

4. Existing Scenarios

5. Government Assisted Activities 


\section{Energy Use Pattems}

\section{Leasing and Permitting Policies}

Uniformity of format from state to state is absolutely essential to allow aggregation of information at higher levels. State baseline data reports should basically be developed from the county level for presentation of resources and commercialization activities. This will facilitate future market penetration analyses.

The baseline data report will be updated semi-annually which will require a review of all of the monitored activities (see Table 4-III). A section will be added in subsequent baseline reports entitled "Trend Analysis" which will present the changes and trends occurring since the original baseline data and most previous updated baseline data reports were published. Monthly activities reports from state teams will be the prime mechanism for reporting leasing, permitting, state regulatory actions and commercialization activities. There are some monitored activities that should be isolated from the state team data gathering system such as Federal Regulations and technology development monitoring (see column 2 of Table 4-II), these should be studied on a national basis to provide a semi-annual or annual report.

Figure 4-6 illustrates the data collection and aggregation flow for the monitoring system. State teams should be utilized where available. DOE funded circuit riders could cover the remaining states. 
In summary, the approach proposed herein should produce a signiflcant amount of progress monttoring data for a reasonable cost and has the benefit of involving the state teams already working commerclalization activities in the field. This system will provide the bulk of the information needed to evaluate DOE comnercialization thrusts, provide a basis for market penetration analyses and program planning. 
TABLE 4-III SELECTED APPROACH TO PROGRESS MONITORING

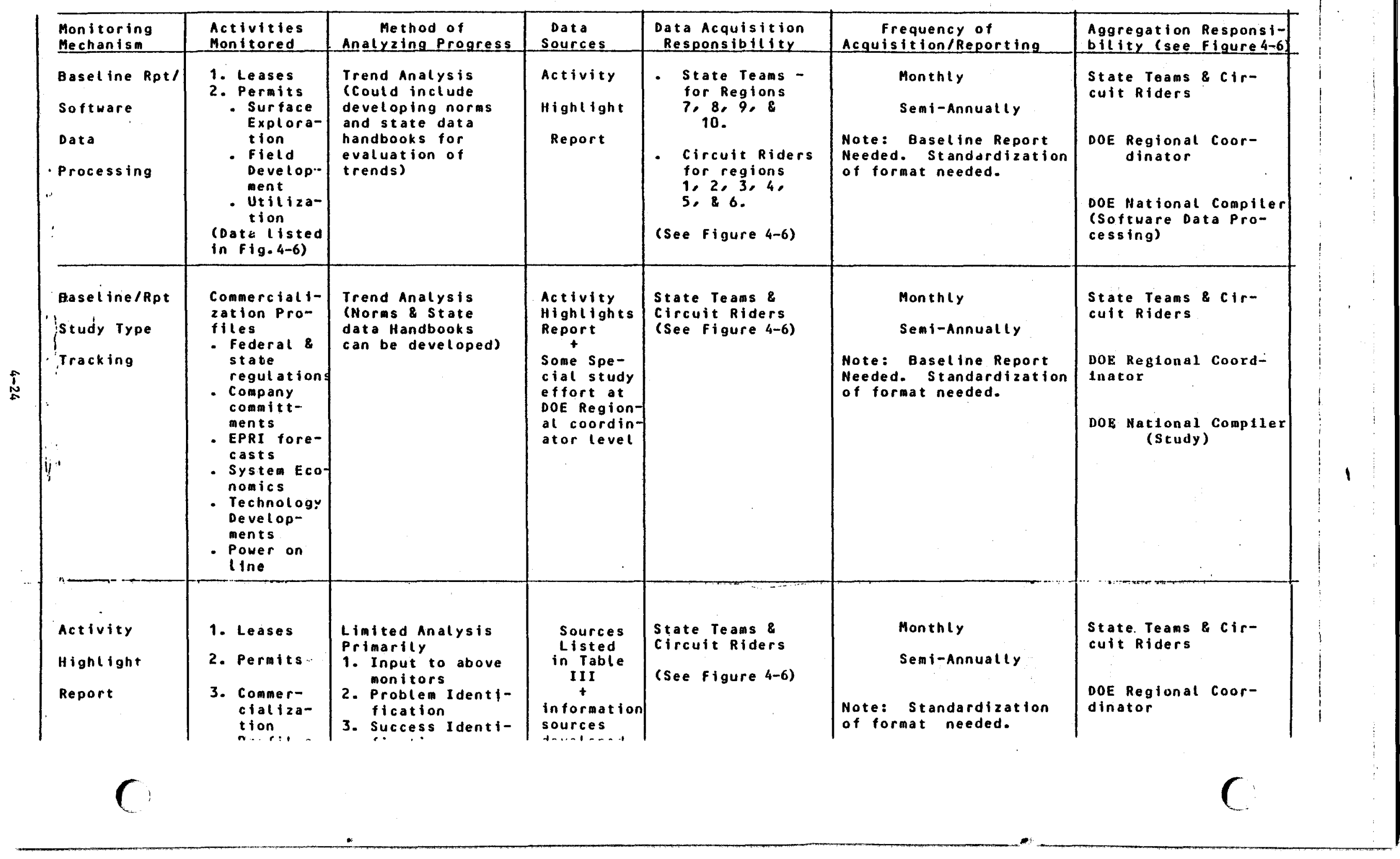




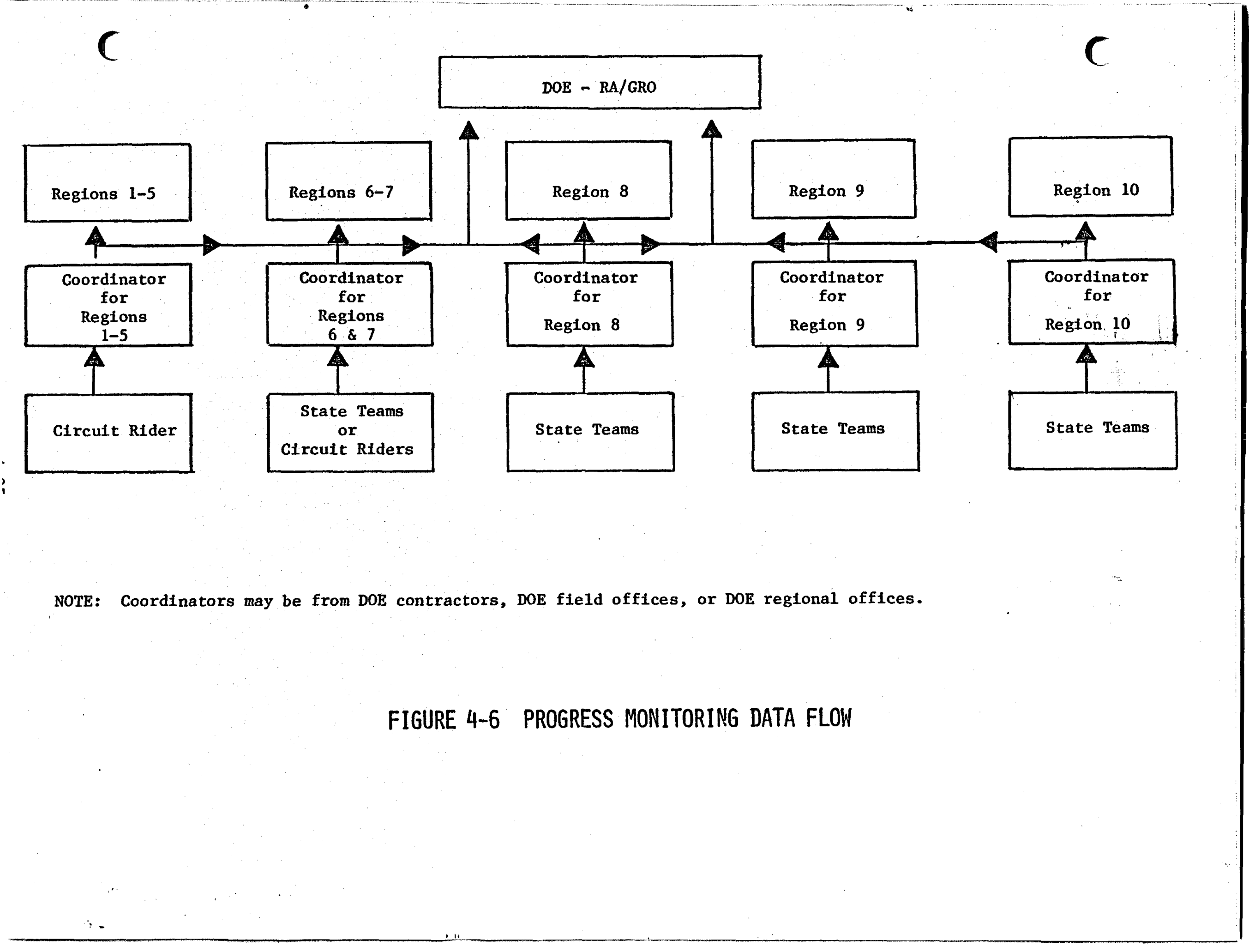





\section{INTRODUCTION}

The minutes of the Plenary Sessions of 1 February, 5 February and the joint session of 6 February, with Rudy Black DOE/RA, are presented in this appendix. These minutes were written by MITRE Staff and were available after each of the sessions. They were mailed to each participant at the conclusion of the Workshop for Individual input. There are minimal changes in the minutes, since first presentation at the workshop. 


\section{PLENARY SESSION}

This report summarizes the Plenary Session held on February 1, 1979, which was chaired by Abdel El-Sawy (MITRE). The information is a compilation of the progress made during the individual Geothermal Commercialization Workshops which commenced on January 29. Representatives of the four workshop groups, Marketing and Outreach, Progress Monitoring, Economics, and Scenarios, presented their progress report and accomplishments during the morning session.

\section{MARRETING AND OUTREACH}

R.J. Schultz (EG\&G/INEL) briefly discussed 20 market preparation documents which were sponsored by the Department of Energy (DOE). One problem encountered during the three day group sessions involvement was the member's difficulty in understanding the "Nuggets". It was decided that the Marketing and Economic groups would hold a joint session to iron out this problem. The basic discussion revolved around Matrix, Needs and "Nuggets".

An outline on Needs Assessment for Commercialization was presented by Dr. W.D. Gertsh (EG\&G/INEL) with discussion following each major category.

\section{NEEDS ASSESSMENT FOR COMMERCIALIZATION}

1. National marketing analys is and penetration strategies.

a. Regional marketing/site specific, and industry.

b. Tailor the PON's. 
2. Resource information and development.

a. A more vigorous low-moderate temperature assessment.

b. A cost shared low temperature drilling program, simflar to present industry-coupled work.

3. Resolution of capital shortage and high investment risk problem.

a. This is immediately flagged.

4. More flexible leasing and regulatory policies.

a. Eliminating or lowering the minimum acreage requirements to 40, this would allow participation by small businesses.

5. Technical assistance and information.

a. A vigorous National effort is required.

6. Accelerated site feasibility screening (PRDA's).

a. To lower maximum funding.

b. Greater number of sites.

7. More timely and higher quality field demonstration plants.

a. Revision of solicitation period requirements.

8. (MIT) Industrial Energy use intelligence and executive commitments.

a. Would like industrial management involvement.

9. Community heating ass istance.

a. Broker access to funding sources in other agencies.

10. Direct application marketing to stimulate use in public buildings.

a. No response.

11. Electricity marketing stimulation.

a. Members of financial community and utilities. 
12. General public information.

a. Must get the word out: example toll free line.

13. Technology specification review.

a. No response.

14. Environmental baseline data rights.

a. Not presently an RA program, but obviously affects commercialization.

15. Technology structure analysis.

a. Availability of drilling rigs, qualified reservoir engineers, etc.

16. Marketing data and monitor.

a. Scenarios development/success of PON's, etc.

\section{PROGRESS MONITORING}

Joe Hanny (EG\&G/INEL) related several areas which were discussed in the monitoring workshop: documents; areas to be tracked; and a requirement 1 ist.

\section{DOCUMENT EXPLANATION}

1. APL - Mini PERT data processing and sumary data sheets basically for the Eastern states have been prepared.

2. EG\&G/INEL, ESL/UURI - prepares a weekly/monthly highlight activities report. There is no progress monitoring against selected standards. The system does provide a quick identification of news items which would be beneficial to the RA Manager. This information is obtained from State planning teams and resource identification teams.

3. JPL - Status indicators, key events, tracking information.

4. LBL - Work plan for FY78-82 includes a computerized reporting and monitoring system. 
5. SAI - Pacific region progress monitoring system slanted towards tracking progress against site-specific scenarios.

\section{KEY ELEMENTS IN THE TRACRING PROGRAM}

1. Leasing/permits procedures.

2. Surface exploration.

3. Field development.

4. Utilization mechanisms already in place should be utilized and developing new mechanisms should be accomplished only if necessary.

This group is still collecting data base information to determine which direction to take and what materials will be necessary. They have not developed, as of this date, identification of the key items needed to be tracked. However, the first requirement and most essential is the permit.

There were suggestions and discussions offering guidance in specific areas:

1. There must be explicit requirements, separating the needs from the wants.

2. Must be able to judge if power-on-line goals are reached.

3. Must get substantial information to the users.

4. The DOE needs information on where problems exist and what to use the data for.

5. Progress information is needed from industry to relate to Congress and the public.

6. The level of details need to support policy evaluation as needed and is different from those required to defend the budget.

7. There is a need of tracking the status of Geothermal development in the market place as well as programmatic progress. 


\section{ECONOMICS}

Tom Lawford (EG\&G/INEL) discussed the areas which have been completed and those which require more work.

WORR COMPLETED

1. The work of MIT was reviewed and documented.

2. 19 of the "Nuggets" were documented, summarizing the status of most past work.

The economics group will review the purpose, work remaining and design an overall approach. Program guidance, policy and technical aid to marketing is one important remaining area.

\section{SCENARIOS}

Fletcher Paddison (APL) presented their progress in cataloguing the scenarios function, use and interaction with possible progress monitoring.

The group has catalogued the following reports: APL, JPL, SAI, SDC, EG\&G/INEL, MITTRE, OIT and The Futures Group.

There are four categories of Scenarios each for a different purpose:

1. Market assessment: generic.

2. Planning scenarios: In the case of potential electric generation it quantifies the resource potential, in the past rather independent of the market. In the case of non-electric it quantifies the resource potential and projects use of resource limited by colocated market. Both scope potential and can be used to establish goals.

3. Site prospectus: A road map for how to apply a specific resource. Includes economics, details of site, local markets, 
projected market participation, and therefore may be the beginning of marketing in the area. This effort can assist marketing and the identification of issues where Federal and State action has to be taken. This also requires regular dialogue with the local groups.

4. Implementation of specific sites: committment (nuts and bolts) drilling, tests, etc.

Inputs to the planning effort useful to: progress monitoring are (the various types of planning effort have been discussed with progress monitor group).

1. Establish potentials and goals.

2. Develop strategies for market analysis and allocation of Federal Resources.

3. Initiate and promote marketing in specific area.

4. Identify R\&D, legal, institutional and other issues requiring state, federal or local action.

Randy Stephens (DOE) questioned meaning of the word "implementation" (Scenarios) as this term conflicts with a word utilized in a different context. The Scenarios group decided to discuss this and report a possible change at the next Plenary Session. Randy Stephens also suggested that the Scenarios group exchange information frequently with other groups to insure that all know the function of the scenarios.

In further discussion Lew Werner (DOE) suggested action must be taken in the field and incorporated in the program to promote marketIng of Geothermal Energy. Jim Close (EG\&G/INEL) related several examples and studies conducted in the Colorado area which proved successful, e.g. field work in the community which gained support for Geothermal Energy. 


\section{PLENARY SESSION}

The Plenary Session of February 5, 1979 and the joint session of February 6, are incorporated in this report. Steve Goldstein (MITRE) chaired both sessions and briefly discussed the remainder of the Geothermal Commercialization Workshops. He also explained that John Leigh (MITRE) drafted a paper regarding assumptions which will be distributed for discussion and used as a springboard to Identify major assumptions.

Steve Goldstein also discussed a briefing by USGS, scheduled for February 6, regarding Circular $\$ 790$, an update to Circular $\# 726$.

The representatives of each group, Scenarios, Economics, MarketIng and Outreach and Progress Monitoring, presented a progress report of accomplishments of the workshops since the last Plenary Session held on February 1.

\section{SCENARIOS}

Fletcher Paddison (JHU/APL) described the effort of the Scenario's working group. This group reviewed all documents with the exception of the OIT report. The group proposed different types of planning objectives, and discussed the potential utilization of scenario Information for comercialization support activities and for setting program objectives. 
I. TYPES OF PLANNING EFFORT UNDERWAY:

1. Preliminary matching of markets and resources.

2. Plan or strawman for Geothermal development as to each site.

3. Site prospectus for each scenario.

4. Site schedule.

5. Program implementation proposals.

THE PLANNING EFFORT FOR SCENARIOS HAS TWO MAIN OBJECTIVES:

1. To develop Federal strategies and allocation of resources:

a. this was started for electric generating projects with data, that are limited to sites rather than to the market.

b. non-electric program needs methodology to evaluate resources are to be used for supply curves.

2. To identify problems.

a. Since problems have not been thoroughly collected or assessed, action is needed toward accomplishment of this objective.

II. THE COMMERCIALIZATION SUPPORT ACTIVITY:

There are three objectives:

1. Preparation of site prospectus, planning information needs to be compiled if marketing packages are to be prepared for early steps in marketing.

A. Planning data needed:

1. Reservoir size and engineering details.

2. Local, legal, environmental, institutional requirements.

3. Cost of well and surface plant.

4. Local financial possibility - State, or Federal, or other regional programing development groups. 
5. Cost/million BTU through completion.

6. Projected market penetration, i.e., other benefits.
a. best done by or with local agencies.
b. conditioning toward marketing begins through this dialogue. (Some local agencies have initiated dialogue, however a more systematic approach is needed).

2. Reinforcement of problems.

A. Understanding new Resource and Development (R\&D) and detalled issues, to ald commercialization.

3. Identify key individuals in the area:

A. Though identification is lacking, up to now (local programs are needed for support)

B. Recommend a site prospectus in each area, where activities are planned.

The Commercialization support activity is meant to get results ready for marketing, as site prospectus can possibly be used as a marketing tool. Site prospectus identifies individuals, institutions, etc.

The discussion on Scenarios, Commercialization and Intemational Marketing was quite extensive.

Rudy Black (DOE) questioned whether preparation of site prospectus should be covered as part of a generic program or a specific program, region by region, or state by state. Fletcher Paddison (APL/JHU) explained this has been done, on an area by area basis in the East but in the west on a state by state basis. Eventually the plan is to be site specific in all areas. However, this has not 
been accomplished.

Rudy Black reaffirmed that DOE would need to determine and evaluate the extent of what has been done and what is needed for Commercialization. There is a periodic and urgent need for data, even if it has to be initially superficial for specific regions. DOE also needs an overall generic framework and a specific framework for individual states depending on needs. (There is a framework for managing programs for regions and states). Steve Goldstein (MITRE) pointed out the imbalance between resource-based and industry/user-based scenarios. The Scenario committee has not examined studies like the MIT industry sector (pulp and paper study) reports. So far, the Scenario committee has focused on the perception of the industry.

Fletcher Paddison (JHU/APL) expressed the need for models to accomplish results. Rudy Black (DOE). felt that resource practice background models are needed to update information, as background models are needed to look up tables and to target individual users. Whether this information update programming should be generic or direct, is not known at this time.

Another area which Rudy Black (DOE) discussed was loan guarantees. There must be resource scenarios for 5 or 6 industries to define direct uses of energy flow, temperature quantities, whole application, economics and labor force. Presently, work is being done toward acquisitioning data (MIT food processing). However, more work is needed in this area. These must be examined by scenarios for 
loan guarantees: Richard Gerson (DOE) explained all plants are different, therefore, it would be difficult to use one scenario format which would be applicable to all industries. Presently under consideration is a pilot program to look at commonalities for scenarios.

Rudy Black (DOE) expressed an interest in the possibility of piggy-backing the Geothermal scenarios with solar. As solar scenarios appear to be rather well defined, the geothermal program could gain from or possibly even use solar scenarios as an outline in some areas. Steve Goldstein (MITRE) discussed the area regarding market penetration, and emphasized the need to look at the kinetics of industrial decisions (work of this nature is presently being done by the Earl Warren Institute).

Marty Molloy (DOE/SAN) brought up the possible need for International market penetration (perhaps as a low priority). His suggestion was a "country development plan" that would look at curves for market opportunities. He suggested a project examination of sumary data on Cerro Prieto to determine if it is applicable to the U.S. Burt Barnes (DOE) remarked that the Orkand Business would present some approaches on international marketing work, and possible applications to the U.S. Fred Abel (DOE) asked if we should add International marketing to scenarios. The Earl Warren Institute has presented a proposal for international marketing to RA. 
Fred Abe1 (DOE) questioned how industry scenarios differ from industry marketing programs. One position was that resource base scenarios basically identify the target and potential application and it is possible to study industry as a whole segment.

Rudy Black (DOE) interjected some comments relating to areas which need further studies. PON's would help schools, hospitals, and other institutions to use geothermal for heating, and that it is not unreasonable, and he stressed the need to identify where geothermal application will make the greatest impact. He states that it is essential to identify the big potential users, which would compare geothermal market prospectuses in several categories.

As the discussion wound down it was decided that individual states can be important sources for determining the needs of the industrial users.

\section{ECONOMICS}

Clem Bloomster (PNL) explained the Economic committee's purpose at the workshops: to establish current state of the art in economic knowledge as it pertains to commercialization of hydrothermal resources; to identify gaps in the knowledge and to recommend activities needed to support commercialization; and describe the role of economics in commercialization. This group reviewed and evaluated past and current activities, with a few loose ends which need polish. Also they summarized current status and identified several needs which should be satisfied. 
1. Methodology and models

A. Production cost models.

B. Risk and rellability - reservolr assessment and management.

C. Demand

D. Market penetration - not sufficient historic experience to establish validity of market penetration models.

2. Supply Analysis

A. Electric

1. Supply curve-good.

2. Effect of resource characteristics, technical and financial factors - well understood.

3. Potential impacts of risk and rellability not well understood.

B. Direct applications

1. Supply curves and impacts of major resource characteristics have been developed - but not to the degree that they have been for electrical application.

C. Question of risk and rellability have not been addressed.

3. Demand Analysis

A. Electric

1. Potential demand from electric utilities well established.

2. Potential demand from captive industries not established - e.g. aluminum, mining.

4. Market Penetration Analysis not well developed.

A. No systematic studies of the factors related to the acceptance of geothermal energy. 
PURPOSE OF ECONOMIC ANALYSIS - PLANNING AND MARKETING:

1. Program planning and budgeting

2. Describe and differentiate the market.

A. Help select target for commercialization.

B. Provide quantitative estimate of gross mass production.

C. Identify and define efficient market mechanisms.

Several areas which are presently being worked on by the committee are: prioritization of needs, assessment of where they are in relationship to the whole program; how to address needs to support marketing and a summary of those needs.

Rudy Black (DOE) would like to know the committees goals for the year 2000, and how one can structure an approach to get market penetration numbers, especially for the non-electric market. Presently there is no way of deriving these goals.

In further discussion, with regard to goals and penetration, it was suggested that geothermal poll methodologies from different areas of DOE. The most 1ikely, since geothermal does not know the penetration capability, would be to utilize the solar energy model. The strategy of federal involvement meaning larger buys and large installations of geothermal energy.

The major problem for committee consideration was how to determine a major explainable model for market penetration. 


\section{MARKETING AND OUTREACH}

Bob Schultz (EG\&G/INEL) presented several charts showing the data which are needed for developing commercialization and areas that still need work.

\section{STEPS IN GEOTHERMAL RESOURCE COMERCIALIZATION:}

A. Overview:

1. Technology Development Requirements.

a. Resource exploration.

b. Resource assessment.

c. Resource management.

d. Technology development.

e. Environmental.

B. Resource Development.

1. Resource exploration.

a. (temperature, depth, location)

2. Resource assessment.

a. (how b1g, 11fetime)

3. Resource Engineering.
a. (how best to use)

4. Special technologies.

a. new pumps, materials, method of handling storage and transmission.

5. Disposal Analyses. 
C. Market Analyses.

1. Market definition.
a. Particular usage types.
b. Sizes of market.
c. Location with respect to resource.
d. Density of users.
e. Engineering feasibility.
f. PRDA

2. Market Penetration
a. Cost of competitors
b. Value of special attributes.
c. Effects of fuels availability.
d. Penetration analyses.

3. Identification of Barriers.
a. Environmental constraints.
b. Legal barriers.
c. Institutional factors.
d. Technical limits.
e. Financing problems.

4. Develop Marketing Strategies.
a. Venture, cost/benefits.
b. Scenarios development. 
D. Market Preparation and Development

1. Public education and relations.

2. Encourage favorable legislation.

3. Overcome institutional barriers.

4. Infrastructure development.

E. Marketing

1. Technical assistance.

2. Pub11c information.

3. Financial incentives.

4. Brokering.

5. State and local policy review.

6. Special programs.

7. Workshops, symposiac and conferences, mainly working on outreach program.

Fred Abel (DOE) indicated a need for more information on which to base a national plan to justify the budget for marketing.

Burt Barnes (DOE) questioned the need for the Federal Governments role in marketing and whether the Federal role should provide aggressive outreach actlvities to help individuals make their own decision planning resulting in aggressive follow up. Rudy Black (DOE) stated that future activities, to a great extent can be handled through direct dialogue with states in turn dealing with DOE Reglonal Representative's offices for technical content and assistance. Regional Representatives would have a single contact point with state-level team to provide data rather than with a multitude 
of officers in each state. State Technical Advisory Comittee's (TAC's) would coordinate efforts and prioritize proposals for action and that the RA headquarters will be kept tharoughly informed.

Larry Mann (Regional Office Representative, Seattle, WA) remarked that cost information would be important to the public for marketing and that cost profit statements are needed to judge penetration.

\section{PROGRESS MONITORING}

Joe Hanny (EG\&G/INEL) discussed the uses for Progress Monitoring assessment and essential tracking points. PROGRESS MONITORING ASSESSMENT SOURCES TO DATE:

1. Review Documentation from: SAI - Pacific Region progress monitor. SDC - Regional Program monitoring and progress evaluation. JPL - Information sheets. EG\&G/INEL - Highlight activities report. JHU/APL - Test of minipert to track progress monitoring. JHU/APL - State data sheets. LBL - Workplan for FY78-82 (includes monitoring system).

2. Prepared evaluation matrix of the existing documentation.

3. Prepared a group definition for - why progress monitoring.

4. Compiled a list of essential items to be monitored.

5. Reviewed and outlined points designed by RA.

6. Prepared a matrix of where essential monitoring data can be obtained. 


\section{ESSENTIAL TRACKING POINTS}

1. Issued Leases

2. Issued permits
a. Surface exploration
b. Field development
c. Electric applications - construction
d. Direct heat applications - construction/colocated with drilling activity.

3. Federal regulation changes

4. State regulation changes

5. Company commitments
a. Forecasts
b. Risk money obtained

6. EPRI forecasts

7. Operational system economics

a. Need studies to back commerciallzation.

8. Technology development

a. Industry, pumps.

Rudy Black (DOE) asked how progress monftoring can measure activity or trends for activity, prior to the permit state? This led to the question regarding tracking of private leasing and how this can be accomplished. There is a possibility in the leasing stage that the state or GRC could provide data on private leasing. 
Data can also probably be obtained at the drilling stage. However, no accurate data can be maintained regarding private leasing prior to this.

Rudy Black (DOE) also mentioned the fundamental need indicator; to demonstrate the program to DOE with focus on Marketing and Planning data. 
APPENDIX B

PARTICIPANTS AT THE GEOTHERMAL COMMERCIALIZATION WORKSHOP

B-1 
PARTICIPANTS OF THE GEOTHERMAL COMMERCIALIZATION WORKSHOP HELD ON JANUARY 29 THRU FEBRUARY 9, 1979.

DOE

FEDERAL BUILDING

12 th and Penn.

Rm. 7119

Washington, DC 22461

FRED ABEL

RUBY BLACK

BURT BARNES

DON CLEMENTS

RICHARD GERSON

(202) $633-8755$

ERIC PETERSON

RANDY STEPHENS

11

11

11

"1

$\underline{\text { PNL }}$

PACIFIC NORTHWEST LAB.

BATTELLE-NORTHWEST

SIGMA 4 Bldg.

Richland, WA 99352

C.H. BLOOMSTER (509) 942-4357

FTS $444-4357$

EG\&G/INEL

EG\&G IDAHO, INC.

P.O. BOX 1625

Idaho Falls, Idaho 83401

JIM CLOSE (208) 526-1233/ FTS 583-1233

GUS GERTSCH (208) 526-1801/ FTS 583-1801

JOE EANNY (208) 526-1894/ FTS 583-1894

TOM LAWFORD (208) 526-1844

BOB SCHULTZ (208) 526-9887

DOE/IDAHO

DOE/IDAHO

550 2nd Street

Idaho Falls, Idaho 83401

RUSS LEASE

(208) $5261669 /$ FTS 583-1669

B-3 
JPL

JET PROPULSION LAB. 4800 Oakgrove Drive

Pasadena, CA 91103

CHARLES FREDRICKSON (213) 577-9247

YUJIO NAKAMURA (213) 577-9247 /FTS 792-9247

EARL WARREN INST.

EARL WARREN INST.

1511 ' $\mathrm{K}$ ' Street, Suite 345

Washington, DC

DR. TOM COLE GARDNES (202) 347-0277

DOE/SAN

U.S. DEPARTMENT OF ENERGY

1333 Broadway

Oakland, CA 94612

Mail Code GED

TOM HEENAN

(415) 273-7943/ FTS 536-7943

DR. MARTIN W. MOLLOY

(415) $273-7943$

REGIONAL OFFICE IX

OFFICE OF THE REGIONAL REPRESENTATIVES OFFICE, REGION IX

111 Pine Street

San Francisco, CA 94111

SHARON SELLERS

(415) $556-7130$

REGIONAL OFFICE $X$

U.S. DOE REGION $X$

915 2nd Ave.

Seattle, WA 98174

DR. LARRY D. MANN (206) 442-1842/ FTS 399-1842

B -4 
JHU/APL

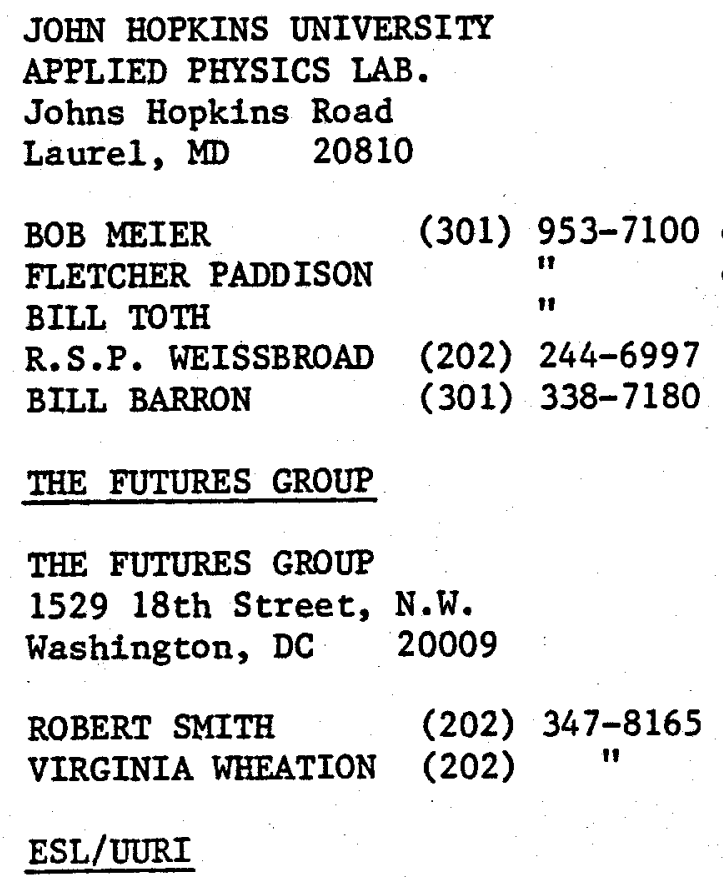

LBL

LAWARENCE BERKLEY LABORATORY

Rm. 367, BOALT HALL SCHOOL OF LAW UNIVERSITY OF CALIFORNIA

Berkley, CA $\quad 94720$

WINIFRED YEN (415) 642-3064

Mess. 642-5125 
MITRE

THE MITRE CORPORATION

1820 Dolley Madison Blvd.

McLean, VA 22102

HARPAL DHILLON (703) 827-6906

ABDEL EL-SAWY (703) 827-6905

DANIEL ENTINGH (703) 827-6906

STEVEN GOLDSTEIN (703) 827-6632

JOLENE ANDERSON (703) 827-6926 